Portland State University

PDXScholar

$5-15-1970$

\title{
Changing the Custody of Children Whose Parents Have Been Divorced: A General View of the Process
}

\author{
Dorothy E. Bateman \\ Portland State University \\ Michael A. Comte \\ Kathryn S. Curry \\ Robert M. Fry \\ Patricia J. Sims
}

See next page for additional authors

Follow this and additional works at: https://pdxscholar.library.pdx.edu/open_access_etds

Part of the Social Work Commons

Let us know how access to this document benefits you.

\section{Recommended Citation}

Bateman, Dorothy E.; Comte, Michael A.; Curry, Kathryn S.; Fry, Robert M.; Sims, Patricia J.; and Terry, Elva J., "Changing the Custody of Children Whose Parents Have Been Divorced: A General View of the Process" (1970). Dissertations and Theses. Paper 855.

https://doi.org/10.15760/etd.855

This Thesis is brought to you for free and open access. It has been accepted for inclusion in Dissertations and Theses by an authorized administrator of PDXScholar. Please contact us if we can make this document more accessible: pdxscholar@pdx.edu. 


\section{Author}

Dorothy E. Bateman, Michael A. Comte, Kathryn S. Curry, Robert M. Fry, Patricia J. Sims, and Elva J. Terry 
AN ABSTRACT OF THE THESIS OF Dorothy E. Bateman, et al. for the Master in Social Work presented May 15, 1970.

Title: Changing the Custody of Children Whose Parents Have Been Divorced: A General View of the Process.

APPROVED BY MEMBERS OF THE THESIS COMMITTEE:

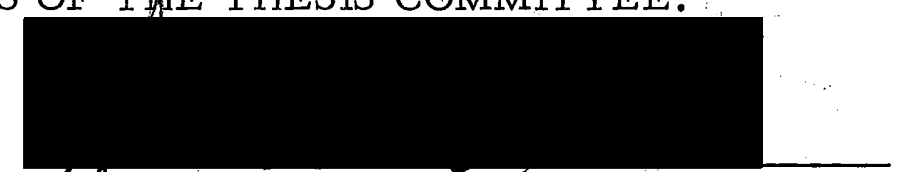

Eblonald G. Welch, Chairman
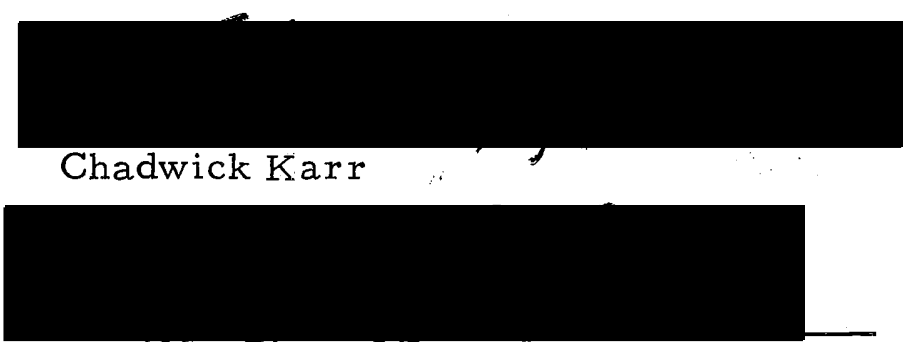

Dale Poteet

The purpose of this project was to obtain a preliminary description, through study of the legal files, of that group of persons who appear before the Court of Domestic Relations for a reconsideration of the custody decision made initially at the time of divorce. A sample of 92 cases heard in Multnomah County in 1965 was obtained.

A survey of the literature revealed that much of what has been written on the subject of divorce and custody is primarily from a statistical or legalistic standpoint and very little bears directly on 
the granting or obtaining of custody or the problems encountered by the custodial or non-custodial parents and the children.

A reading schedule was developed for the purpose of recording the information in the legal files maintained by the court. The characteristics of the sample group were tallied in an effort to obtain a statistical profile of that group requiring additional court appearances to settle the matter of custody. A number of hypotheses were developed and tested by means of Chi Square.

Though this study was limited by the fact that no control group was used and no personal interviews were obtained, it clearly indicates the need for additional research in the area of divorce and custody and suggestions are made for future projects. 
CHANGING THE CUSTODY OF CHILDREN WHOSE

PARENTS HAVE BEEN DIVORCED:

A General View of the Process

by

DOROTHY E. BATEMAN

MICHAEL A. COMTE

KATHRYN S. CURRY
ROBERT M. FRY

PATRICIA J. SIMS

ELVA J. TERRY

A thesis submitted in partial fulfillment of the requirements for the degree of

MASTER OF SOCIAL WORK

Portland State University

1970 
TO THE OFFICE OF GRADUATE STUDIES:

The members of the Committee approve the thesis of Dorothy E. Bateman, et al. presented May 15, 1970.

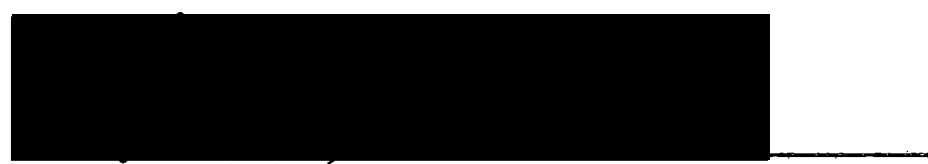

Donald G. Welch, Chairman

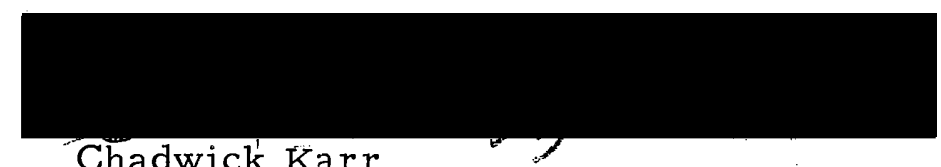

Chadwick Karr

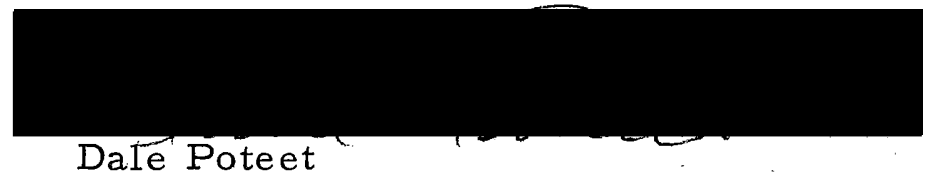

APPROVED:

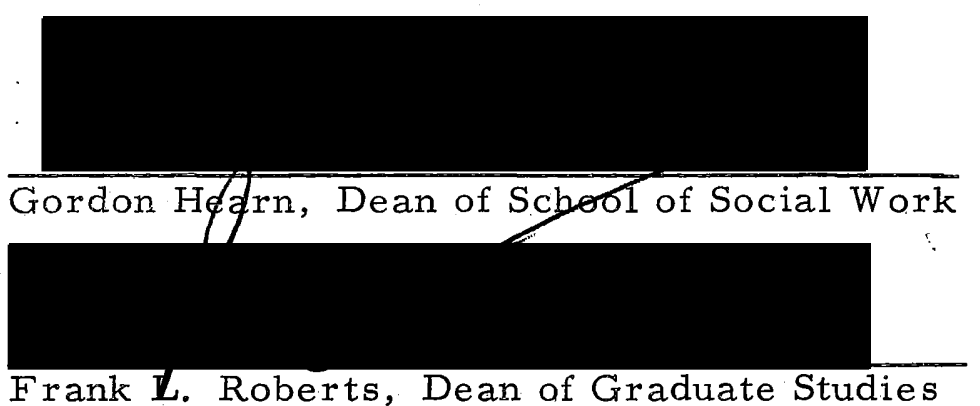

May 18,1970 


\section{ACKNOW LEDGMENTS}

The members of this group project wish to express their thanks and appreciation to Richard E. Collins, Director, Department of Family Services, for allowing us to use the resources of the Department for our research.

We are also indebted to The Honorable Judge Jean L. Lewis, Circuit Court Judge, Fourth Judicial District, Department Twelve, for providing the originalinspiration for this research. Her help in making the appropriate Supreme Court Decision citations proved invaluable to the group.

Finally, our special thanks go to Donald G. Welch, our thesis adviser, who served as our mentor and exegete with energy and enthusiasm. 
TABLE OF CONTENTS

PAGE

ACKNOW LEDGMENTS ...................

LIST OF TABLES ................................ vii

LIST OF FIGURES .......................... xi

CHAPTER

I INTRODUCTION ................ 1

General Statement of the Problem ..... 1

A Broad Generalization about Divorce. . . 2

The History of Divorce. .......... 4

Basis for Determination of Custody .... 10

The Legal Basis for Divorce and Custody in Oregon............. 14

Oregon Supreme Court Rulings ...... 18

The Adversary Process ........... 22

Specific Statement of the Problem ..... 24

Intent of the Study........... 26

II REVIEW OF THE LITERATURE ......... 28

Effect of Divorce on Children ....... 28

Child Custody, Following Divorce ..... 31 
Reasons for Divorce ..........

Statistics of Divorce ..........

Determination of Custodial Parent ....

Modification of Decree; Change of

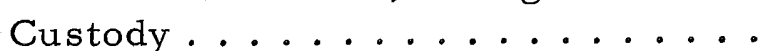

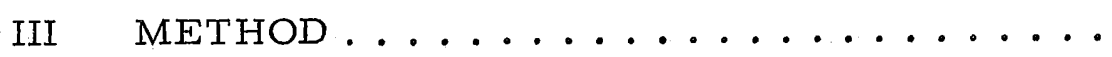

Formulating the Study ..........

Sources of Information ........

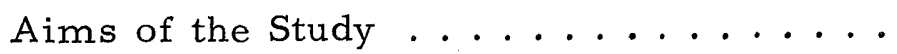

The Court of Domestic Relations in Multnomah County.........

Collection of Data ...........

Explanation of the Reading Schedule ...

The Complaint--Item I

The Answer--Item II

The Cross-Complaint--Item. III

Show Cause Motion for Action

Pendente Lite--Item IV

Answer to Show Cause Motion--

Item. V

Order Pendente Lite--Item VI

Motion to Modify the Pendente Lite Order--Item VII

Order Modifying Pendente Lite

Order--item VIII

The Divorce Decree--Item IX

Motion to Modify Divorce Decree-Item X

Order Modifying Divorce Decree-Item XI

Family Consultant Activity--Item XII Other 


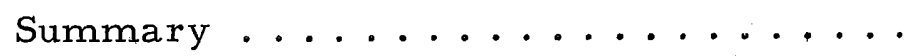

IV $\quad$ FINDINGS $\ldots \ldots \ldots \ldots$

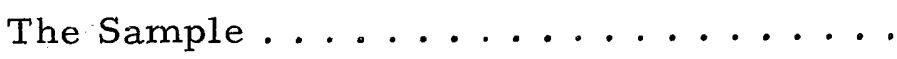

Plaintiff and Defendant .......... 66

The Grounds for Divorce, the Bill of

Particulars and the Changed

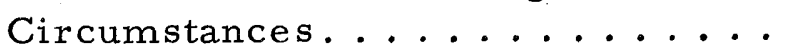

Children ................. 83

Custody Changes .............. 88

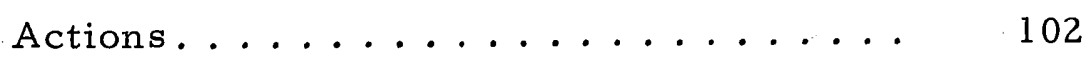

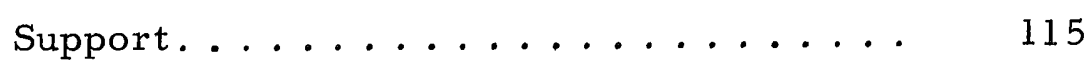

Visitation ..................... 123

Property, Alimony, Court Costs, Attorneys' Fees, Restraint from

Harassment and Move from the

Home................ 125

The Family Services Department .....

V IMPLICATIONS FOR FURTHER STUDY,

LIMITATIONS AND CONCLUSIONS . . . .

Limitations and Conclusions of This

Research Project..........

Implications for Further Study .......

A SELECTED BIBLIOGRAPHY .............

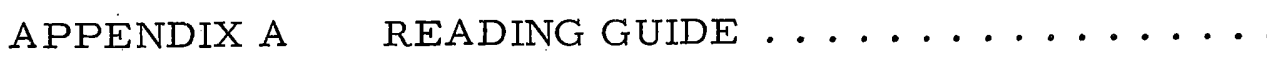

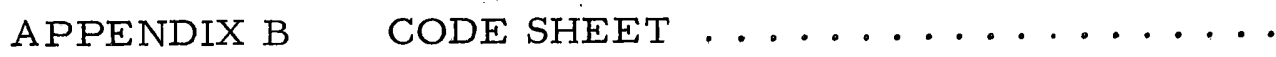




\section{LIST OF TABLES}

TABLE

PAGE

I Place of Marriage ............... 67

II Frequency Distribution of Family Size. . . . . . 84

III Frequency Distribution: Family Size of All

Couples Divorcing in Oregon in $1965 \ldots \ldots 84$

IV Chi Square: Comparison of Sample Family Size

with That of the Family Size of All

Divorced Couples in Oregon in $1965 \ldots \ldots$

V Frequency Distribution: Children's Age at Time

of Filing Divorce Complaint.........

VI Frequency Distribution: Age of Youngest Child

at Time of Filing Divorce Complaint. . . . .

VII Chi Square: Relationship Between Age of

Children at Time of Filing and Number of

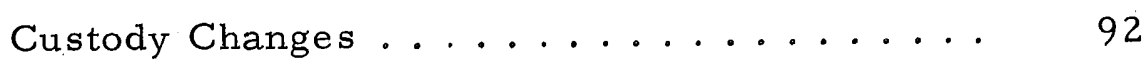

VIII Frequency Distribution: Age of Children at

First Custody Change and Parent to Whom

Custody was Granted.............. 93 
IX Frequency Distribution: Age of Children at

Second Custody: Change and Parent to Whom

Custody was Granted .............. 94

X Chi Square: Relationship Between Length of

Marriage to Filing of Divorce Complaint

and Number of Custody Changes ........ 96

XI Distribution of Custody Through the Legal

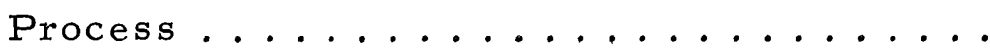

XII Distribution of Custody to Husbands Divided by

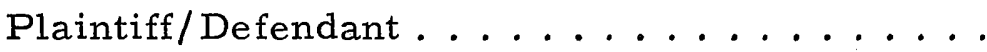

XIII Chi Square: Relationship Between Sex of Plaintiff

and Number of Custody Changes ........ 100

XIV Chi Square: Relationship Between Family Size

and Custody Changes............... 101

XV Chi Square: Relationship Between Family: Size

and Number of Court Actions ......... 105

XVI Chi Square: Relationship Between Length of

Marriage to Filing of Divorce Complaint

and Number of Actions............ 106

XVII Chi Square: Relationship Between the Number

of Court Actions and Custody Changes ..... 107 
XVIII Frequency Distribution: Length of Marriage to

Filing of Divorce Complaint ........

XIX Frequency Distribution: Length of Legal Process

XX Frequency Distribution: Difference Between

Time Spent in Court and that Spent in

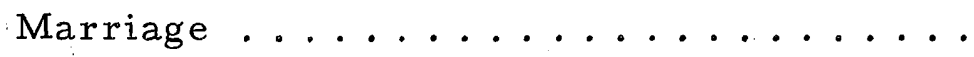

XXI Frequency Distribution: Ratio of Length of Time

in Legal Process to Length of Marriage... .

XXII Chi Square: Relationship Between Sex of Plaintiff and Whether or Not the Marriage Lasted Longer than the Legal Process........

XXII Chi Square: Relationship Between Family Size and Whether or Not the Marriage Lasted Longer than the Legal Process........

XXIV Chi Square: Relationship Between Custody

Changes and Whether or Not the Marriage

Lasted Longer than the Legal Process .....

XXV Chi Square: Relationship Between the Number of Actions and Whether or Not the Marriage Lasted Longer than the Legal

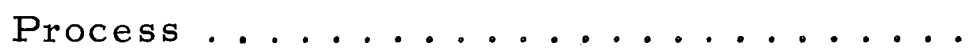


XXVI Frequency: Distributions: Amount of Support Per

Child Per Month at Complaint and Divorce

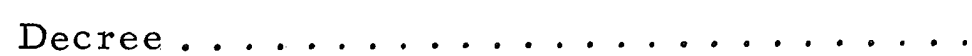

XXVII Frequency'Distributions: Total Support Per

Family 'Per Month at Complaint and Divorce

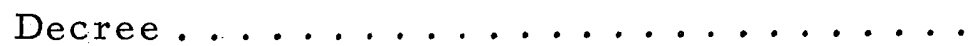

XXVIII Chi Square: Relationship Between Total Support

Per Family at Time of Complaint and

Number of Court Actions ...........

XXIX Chi Square: Relationship Between Total Support

Per Family at Time of Complaint and

Number of Custody Changes .........

XXX Description of Visitation Through the Legal

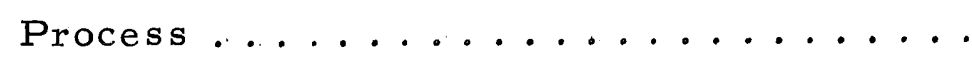

XXXI Frequency Distribution of Specifications of

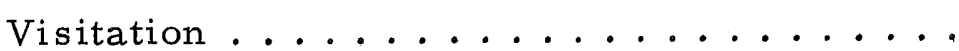

XXXII Chi Square: Relationship Between Division of

Property and the Sex of the Parties.....

XXXIII Chi Square: Relationship Between Number of

Court Actions and Whether or Not Family

Services Department was Seen ....... 


\section{LIST OF FIGURES}

FIGURE

PAGE

1 Length of Marriage to Filing of Divorce

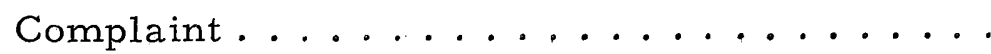

2 Time Lapse Between Filing of Complaint and

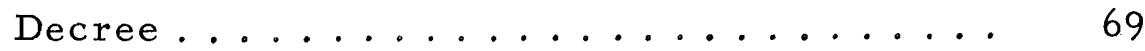

3 Length of Marriage to Divorce Decree........ 70

4 Time Lapse from Filing of Divorce Complaint

to Last Court Action............. 70

5 Time Lapse Between Divorce Decree and Last

Court Action ..................... 71

6 Year from Date of Marriage to Last Court Action.. 71

7 Particulars at Time of Complaint. Division by

Sex of Reporting. Party ........... 77

8 Sub-categories of Particular E, Physical Abuse . . 78

9 Sub-categories of Particular F, Verbal Abuse.... 78

10 Sub-categories of Particular M, Other...... 78

11 Particulars at Time of Cross Complaint.

Division by Sex of Reporting Party. . . . . 79

12 Sub-categories of Particular F, Verbal Abuse.... 81

13 Sub-categories of Particular M, Other....... 81 
14 Location of Custody Changes Within the Legal

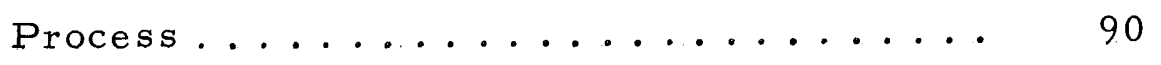

15 The Legal Process and the Frequency of Each

Court Action ................... 103

16 Places of Intervention in the Legal Process by

the Family Services Department........ 130 
CHAPTER I

\section{INTRODUCTION}

\section{GENERAL STATEMENT OF THE PROBLEM}

The three Circuit Court Judges in and for the State of Oregon, County of Multnomah and sitting in the Department of Domestic Relations have all expressed their concern over the fate of children involved in the divorce process. The Honorable Jean L. Lewis, in particular, has expressed concern about the children who are emotionally torn by the continuing parental battle following the granting of the divorce decree. This continuance of the fight is frequently expressed in subsequent pleas to the court for a change of the custody order initially granted. Although the legal procedure for handling this action is clear, the "why" of the process is complex, frequently obscure and causes considerable anguish to the concerned jurist who must bring order out of an involved emotional dispute by using the mechanics of a legalistic decision. It is in an attempt to bring some beginning understanding to a complicated subject that this research is addressed. 


\section{A BROAD GENERALIZATION ABOUT DIVORCE}

Family dissolution has been a source of societal concern and legislation as far back as history is recorded. There are three means by which families can be split: (1) divorce, (2) separation, and (3) death. All three are traumatic events sometimes occurring suddenly and sometimes requiring the lapse of much time before the actual event happens. All three entail a loss. All three require extensive readjustment: physical, financial and emotional. It is in the finer detail of feeling that divorce and separation differ markedly from death. In this paper we shall deal with one small segment of the phenomenon of divorce.

Divorce affects not only the individuals within a group but the group as a whole and therefore is a legitimate matter of concern to a society. All civilizations and societies have the family, in one form or another, as a base; the smallest unit of the whole. The whole is radically affected by the events which transpire in the base unit. As a consequence laws are established to govern and control that which may adversely affect the total organism. All societies have some legal provision for keeping families together. There are laws governing both marriage and divorce. Protection is provided both to the individual and the group by the laws of the group establishing the circumstances under which both marriage and divorce may occur. 
Since the need of the total group is to keep the sub-group intact, the laws allowing for the establishment of the marital contract are far more lenient than those providing for its dissolution.

Divorce is not only seen as a threat to the total group but, more obviously, is seen as a catastrophic event to the individuals involved. This base family unit must be composed of at least two individuals but can be composed of a much larger number. The important decisions for this family unit are usually made by two core people, the marital partners. Their behavior, attitudes and decisions have far-reaching effects. What either one or both marital partners decree shall happen to the family unit is not necessarily what the other family members want but since this is not a democratic institution the wishes of the marital pair, either jointly or singly, tend to govern the unit activity. Especially in divorce the wishes of one partner can rule the family unit since it often takes only one dissatisfied member to dissolve the marriage. Thus, in the eventuality of divorce, the core partners or parents are sometimes in agreement and sometimes not. Whether or not they are in agreement the remaining family members, the children, are frequently caught in the conflict area. Since the children, is sue of the core members, are part of each parent, their loyalties can be expected to be divided. They will not want to suffer loss, loss being an integral part of family dissolution. Neither will they want to give up their 
identity: with the departing parent, although the remaining parent may subtly require this. (See reference to Dominian, Chapter II, page 33.) Since these children cannot physically be divided in half they must live with one or the other of the family core members, perhaps eventually to become a part of an altered family unit with at least one different core member. Sometimes this process can occur without appreciable difficulty; all the bits and pieces of emotion gradually and smoothly fitting into place. U Usually the process of dissolution and resettlement is traumatic to a greater or lesser degree. The courts, in the process of enforcing the societal laws, play a major part in this human drama at least once and sometimes repeatedly. This research project is a descriptive study of families who appear before this court more than once.

\section{THE HISTORY OF DIVORCE}

Isabel Drummond (1931) says that the first divorce was accomplished by administering poison. Institutionalism of both marriage and divorce did not arise until the acquisition of property. The wife then became the husband's property to do with as he saw fit, including divorcing her. As civilization developed the wife acquired some rights, usually through her dowry and some equality.

Bardis (1964) makes an excellent comparison of early patterns of divorce. In the ancient Hebrew family the double standard was 
reflected in divorce policies. It was neither a civil nor religious concern but a ceremonial matter. It was considered the right of the husband to simply hand his wife a bill of divorcement. In the seventh century B. C. the Deuteronomic Code attempted to protect the wife by instituting some restrictions making divorce less hasty. The Misnah, a collection of oral laws which became the basis for the Talmud, added further restrictions. Children in divorce remained in the woman's custody until they were weaned. After that time it was optional with her to retain custody but the father could claim custody of the boys after they: were six.

Bardis (1964) says that not much is known of ancient Greek divorce laws. In the few writings reference is mainly to Athens. Divorce was generally a private matter except that the state interfered to some extent in the case of adultery. In the event of divorce the wife's dowry was returned to her family. The wife was also allowed to divorce her husband with his consent; otherwise she had to supply evidence of his cruelty. In Greek divorces witnesses were required and the husband was required to pay alimony.

Bardis (1964) notes that in ancient Rome there was no divorce. Some authors believe that as late as $23 \mathrm{~B}$. C. the first divorce was granted although earlier men perhaps did divorce their wives. Divorce was considered a private matter. Judicial procedure was unnecessary unless there was disagreement over the property or 
children. In later centuries divorce became exceedingly common and was considered socially acceptable.

In the Christian family, according to Bardis (1964), emphasis was usually placed on the indissolubility of marriage although some early Christian fathers accepted limited grounds as reasons for divorce. This lack of agreement is indicated by the debate of Christian leaders over the matter for 1,100 years before completing the ecclesiastical code dealing with the matter. Drummond (1931) goes on to explain that the influence of the early Christian church made marriage a sacrament. To marry was at first a confession of weakness and therefore divorce was a question of greater weakness. Marriage was not valid except under church sanction and therefore became a holy prison. Men's adulteries were excused; women were subjugated to their "lord" until the nineteenth century.

Drummond (1931) felt that lack of unity of interpretation and confused thinking characterized actual practice and contrary to Christian dogma concerning the indissolubility of marriage, marriages were in fact dissolved. Nearly all divorces were obtained by men. Public prejudice against women, her economic dependence and restrictions of the law made divorce for her extremely difficult. She was expected to suffer as part of God's will and as expiation for the sin of being a woman.

Drummond (1931) finds that the influence of the church on 
divorce legislation begins in the fourth century when church dogma was incorporated into secular law and expanded by the prevailing church authorities of the times. Consent to a divorce by the other party was regarded as collusion and could prevent the granting of a remedy, except where the parties were wealthy or powerful, in which case consent was encouraged. This doctrine has been clung to uncompromisingly in form, if not in practice, and is in effect today throughout the United States.

She notes that the age of canon law came to an end with the Reformation. However, secular law tended to adopt the same principles which had been held by canon law and "crime" was still considered to be the legal base for divorce. The position of women was not much changed by the Reformation either. Woman and her belongings continued to be the husband's possessions.

Drummond (1931) points to the French Revolution as probably producing more change in divorce laws than any other single movement. The principles of Roman law were re-established in which men and women were proclaimed to have both rights and duties in marriage, which was again proclaimed to be a civil contract. Divorce by mutual consent did not become established but the dogma of the indissolubility of marriage was gone.

Despite changes, Drummond (1931) reveals that canon law was allowed to remain in effect in ecclesiastical courts. Henry VIII 
appointed a commission to revise it but his death prevented the recommended liberalizations from being made and Catholic canon law continued to hold sway in a Protestant country. It is English common law, founded on canonistic doctrine, on which most United States legislation concerning marriage and divorce is based.

Drummond (1931) explains that marriage in America has always been a civil contract since colonists had no established church or ecclesiastical courts. But many of the anachronistic principles of canon law were a potent force in defining grounds and establishing restrictions and inequities. One of the essential elements of a contract has been the right to dissolve it for cause and some countries recognize divorce by mutal consent. In the United States there is hypocritical knowledge of prohibition in law, if not in fact. She writes,

The powers exercised by judges in America parallels to a great extent that of the emperors, popes and ecclesiastics, for the discretion allowed them in divorce matters within a more or less formal, if restricted, framework of grounds, is almost unlimited. With their inherited and acquired prejudices of one kind and another common to the human race in general and with the growing disregard, particularly on the part of women, of institutionalism, it is easy to understand how hide-and-seek methods are used to gain desired ends.

Grounds for divorce and motives which cause the suit are seldom the same but the inheritance of dogmatic beliefs prevents bringing the two together. 
Madden (1931) points out that the view of canon law regarding the indissolubility of marriage was applied by the ecclesiastical court in England. This latter court which had jurisdiction over marriages, did grant an incomplete divorce, a judicial separation, called a mensa et thoro, upon strict proof of gross misconduct by either party. This meant no collusion between the parties and only authorized separation without dissolving the marital bond and with no provision for remarriage. Total divorces in England were not known prior to 1857. Annulments, a vinculo, were granted which rendered the marriage void from the beginning. The condition that no marital offense was considered sufficient cause for divorce proved unsatisfactory. As early as the sixteenth century some efforts were made to provide for divorce. A few divorces were granted by Act of Parliament, which meant only the wealthy could obtain relief. In 1857 the Court of Divorce and Matrimonial Causes was established, thus removing jurisdiction from the ecclesiastical courts.

Madden (1931) notes that in the United States there were no ecclesiastical courts. American courts of equity did not have divorce jurisdiction until it was conferred by legislative statutes. Judicial divorce was established in this country much earlier than in England; in Pennsylvania as early as 1785. Since marital status was considered to be a matter of public interest, the legislature could prescribe grounds for divorce. Divorce action was not considered a 
private controversy between two individuals. The state is interested as an adverse party so far as to oppose the granting of divorce except within the prescribed legislative rules. Since the state favored continuity of marriage relations, there is no common law of divorce in the United States and divorces may be granted only as provided by statute.

\section{BASIS FOR DETERMINATION OF CUSTODY}

Historically, the mother has had few rights where the children were concerned. This has been in the process of gradual change over the years so that at the present parents either have equal rights or the mother would appear to have superior rights to the children.

By the common law of England, Madden (1931) states, the father had an almost absolute right to the custody of his legitimate children. In the law courts it was practically impossible to make a showing of unfitness against the father. Cases of the most extreme sort appear in English history in which fathers, morally unfit to have custody of their children, have yet prevailed in the courts. The reason for this extreme position was a practical one; the support of the child had to be provided by someone and unless a child had property of his own there was reluctance to remove him from his father. The inferior position of married women with reference to their income and earnings had its effect upon the practicability of the 
Chancellor's removing the child from his father.

Madden (1931) reveals that in 1839 in England, the power of the Chancellor to determine custody was conferred by statute as to infants under age seven and in 1886 was changed to include infants of any age.

In the United States the strict view of the father's rights as taken by the English courts was never adopted, according to Madden (1931). The welfare of the child has always been the controlling circumstance. Very young children were frequently placed with the mother, if she was fit, unless awarding the child to her would tend to encourage her to remain away from her husband. When the child reached the age where it no longer peculiarly needed the mother's care, the father as head of the family and entitled to the child's services and under a duty to support it, was entitled to custody unless he was unfit or unless the child's welfare would be harmed by: being with its father. In some states statutes were enacted declaring rights of the father and mother equal. The court would seem to have a free hand in selecting the custodian. However, the father's right to select a home and his duty to support tended to give him preference over the mother.

Drummond (1931) notes that children, during their minority, are wards of the state. This supreme guardianship grows out of the tripartite marriage relation between man-woman-state. Natural 
parents are considered trustees but this position depends upon the successful discharge of their responsibility. Dereliction of duty calls for assertion of the state's authority. This is why the courts, under their general chancery powers, have jurisdiction in divorce over the offspring of the marriage and their property whether there is statutory authorization or not. All states now have enacted legislation regarding custody and support from divorced parents.

Drummond (1931) finds the majority of courts holding that, where the children are outside the jurisdiction of the state at the time this jurisdiction was taken, the court has no power to award custody in the decree. Once jurisdiction has been acquired, however, the court retains this throughout the minority of the children and it may be invoked at any time. In many states statutes are sufficiently broad to permit the court to make a temporary determination of custody pending final action. The general practice is to make an award of custody in the final decree.

Madden (1931) says that the court in exercising its discretion in awarding custody looks to the best interest of the child. Historically, the mother is frequently given custody of very young and sickly children and there is some tendency to give girls to the mother and boys to the father. The winning party in the divorce suit may or may not gain custody. The award may be made to the guilty party: in light of the children's best interests. Where children have reached 
the age of discretion (a term generally undefined in the law and the literature) and the parents are of equal fitness the court frequently concedes to the child's.wishes. If one parent is fit and the other unfit, custody will be awarded to the former.

Drummond (1931) specifies that visitation is usually allowed to the parent not receiving custody. This privilege may be withdrawn by the court but a finding of fault or guilt relative to the divorce is not, of itself, sufficient reason to deny visitation.

She notes that as a rule statutes also provide for the support and maintenance of minor children although if relief is not prayed for in the divorce petition the decree is usually silent on the question. The tendency is to stress relevant facts bearing on the welfare of the child as well as on the financial abilities of the parent and to recognize a continuing liability on the part of the father to support his children.

She, explains that decrees are subject to modification where changed conditions require a revision of the existing order. Madden (1931) explains that the award of the children to one parent or the other does not permanently settle the right of custody. A change of circumstances may authorize the court to order a change of custody. For example, if a mother following an award of custody to her, becomes unfit the custody may be granted to the father if he is fit. Where a parent to whom custody was awarded, even though it may 
have been because of the unfitness of the other, afterward dies, the other may obtain custody by showing that he has become fit or that it is in the child's interest. Drummond (1931) indicates that some courts take the view that upon the death of one parent the other parent is automatically entitled to custody.

\section{THE LEGAL BASIS FOR DIVORCE AND CUSTODY IN OREGON}

The appropriate statutes are set by the legislature. Application of them is made by a duly elected official, a judge, in a court of equity. An appeal from the trial judge's decision may be taken to the Supreme Court of the State of Oregon. The hearing in the Supreme Court is de novo on the record made, i. e., the court can rule on the facts a second time.

The first divorce law in Oregon was enacted in 1862. There have been a number of revisions since. The present law was enacted by the 47th Legislative Assembly in 1953, with revisions in 1955 , 1959, 1961, 1963 and 1965. The legal basis on which divorce may be granted is established under Oregon Revised Statute (hereinafter referred to as ORS) 107.030 "Grounds for Divorce." The dissolution of the marriage contract may, be declared at the suit or claim of the injured party for any of the following causes:

1. Impotency existing at the time of the marriage and continuing to the commencement of the suit. 
2. Adultery.

3. Conviction of a felony.

4. Habitual gross drunkenness contracted since marriage and continuing for one year prior to the commencement of the suit.

5. Willful desertion for the period of one year.

6. Cruel and inhuman treatment or personal indignities rendering life burdensome.

7. Permanent mental illness where the defendant has been adjudged mentally ill by a court of competent jurisdiction.

In practice cruel and inhuman treatment is the most commonly stated basis and in this study was almost the only basis for filing which was used by the parties in our sample.

The aforementioned revision in 1961 provides that the father shall have equal opportunity with the mother to gain custody of the children. The court's strong language regarding gross depravity of the mother as an influential factor in determining custody occurred prior to this 1961 amendment providing for equal opportunity between the parents. There are three pertinent sections of the Oregon law which deal with award of custody and modification of the decree.

ORS 107. 090 vests power in the courts to grant custody pendente lite (pending litigation). 
1. After the commencement of a suit for dissolution of the marriage contract or to have a marriage declared void and before a decree therein, the court may, in its discretion, upon proper showing of the necessity therefor, provide by order as follows:

a.

b. For the care, custody and maintenance of the minor children of the marriage during the pendency of the suit.

ORS 107. 100 provides for the award of custody as part of the

divorce action.

Whenever a marriage is declared void or dissolved, the court has power further to decree:

a. For the future care and custody of the minor children of the marriage as it may deem just and proper. In determining custody the court shall consider the best interests of the child and the past conduct and demonstrated moral standards of each of the parties. No preference in custody shall be given to the mother over the father for the sole reason that she is the mother.

ORS 107. 130 grants statutory authority for the modification of the decree by subsequent judicial action.

1. The court, or judge thereof, has the power at any time after a decree is given, upon the motion of either party, to:

a. Set aside, alter or modify so much of the decree as may provide for the appointment of trustees, for the support and custody of minor children, for the nurture or education thereof, or both, or for the maintenance of either party to the suit.

On the basis of these statutory provisions a judge makes a decision which in substantial measure determines the future direction 
of the individual families. The phrase, "best interest of the children" is vague and ill defined. The statutes do not make specific mention of the basis which warrants a change in the custodial parent. The basic factor which must always be met is "a change in circumstances." The Oregon Supreme Court has affirmed and reaffirmed this requirement through their interpretations. In Bogh vs. Lumbattis (1955), considered a basic case on which many other decisions and interpretations rest, the Court said,

An application for modification must show there has been a change in the conditions and circumstances since the last order respecting the child's custody and that such change is adverse to the child's welfare. The petitioner must further demonstrate that the change of custody proposed would be to the child's benefit.

The Court also said in Bogh vs. Lumbattis (1955), "The best interests of the minor are the governing criterion. What are the best interests have to be determined from the facts of each case."

Supreme Court decisions constitute a body of accumulated interpretations by which the jurist is governed and guided in his or her task. There are inconsistencies in the se rulings which make actual application a difficult and often peremptory matter. The inexact and undefined nature of the subject matter allows for considerable latitude on the part of the trial judge but also for much uncertainty as to whether he or she will be upheld or overruled by the superior court. Robert Furlong (1962) in his article for the Willamette Law 
Journal provides a review of Supreme Court decisions as they relate to provisions for custody of children. He cites several cases which make up this body of accumulated interpretations by which trial judges are governed in both their original and subsequent rulings.

\section{OREGON SUPREME COURT RULINGS}

A brief overview of Supreme Court Decisions made during the past twenty years points up the dilemma with which the trial judge is faced.

In Gallagher vs. Gallagher (1949), the Court finds that,

. . general rules frequently do not decide specific cases. Moreover, all rules of the kind just mentioned must yield to one of which we have already taken notice; that is, that the welfare of the child is of supreme importance.

In Goldson vs. Goldson (1949),

The moral unfitness of the mother sufficient to deprive her of custody must be such as to have direct bearing upon the welfare of her child. It is not for every, act of indiscretion or immorality that she will be denied custody. The test is whether her conduct is so depraved, immoral or wicked that to permit her child to remain in her custody would be injurious to its best interests.

In Gibson vs. Gibson (1952),

In endeavoring to do what is best for the child, it is clearly our duty to take into consideration the suitability of each parent for the grave responsibility which it seeks. Suitability includes, as its most important element, character.

Pick vs. Pick (1952) held that a parent was entitled to custody as against a grandparent and said,." . . paramount consideration is 
the welfare and best interests of this baby girl. We should not, nor will we, permit her to be a pawn in the battle between her parents. " Hendrickson vs. Hendrickson (1961) says that not only must there be an improvement in circumstances of the moving party but a worsening of the situation of the other parent.

It is not enough to show that the petitioning parent is better able to now care for the child than when the custodial order was made. [The petitioning mother] . . has failed to show any changed conditions, material or otherwise, that has occurred.. . . in the father's ability or inclination to care for the child in the best manner or that the welfare of the child has suffered by reason thereof.

In Shrout vs. Shrout (1960) the rule regarding moral unfitness of a mother as stated in Goldson vs. Goldson (1949) was overruled and the Court then went on to say:

We affirm the rule that not every act of indiscretion or immorality should deprive a mother of the custody of her children. In all cases motherhood is a factor to be given great weight in deciding questions of child custody. We only want to make it clear that any moral transgressions of the mother must be considered, together with other relevant factors, in determining what is best for the children. We think that arbitrary rules that exclude immorality as a relevant factor unless it is "gross," and "depraved, "or "wicked" or "unless it has a direct bearing," serve only to hamper the trial courts in weighing all the evidence and in arriving at a decision which will promote the welfare of the child.

In a number of cases the Court holds that the trial judge who hears the evidence and observes the parties has an advantage over the Supreme Court jurists who only review the record, and are reluctant to change the trial judge's ruling. Bennehoff vs. Bennehoff 
(1956), Shrout.vs. Shrout (1960) and Kroll vs. Kroll (1965) all cite this principle.

In James vs. James (1966) the children were awarded to the plaintiff father in the original decree. He placed them with the defendant's mother for care; the defendant was living in the same home. Less than six months later the mother filed for modification of the decree on the basis of her reformed behavior; she was no longer associated with the man with whom she had been having an affair prior to the divorce. The motion was denied and the decision upheld, apparently due to the short length of time of reformation.

In Cox vs. Cox (1967) the court held that "A motion for a change in custody is not available to vindicate wounded pride nor to punish the real or imagined social blunders of a former mate."

In Kightlinger vs. Kightlinger (1968) it was ruled that in a situation in which both parents have demonstrated good care of children, the best interests of the children are best served if custody is awarded to a parent who can support them. The Court held:

Allowing for all the subtleties of testimony that slip away from a reviewing court, consistent threads of evidence establish these facts:

1. The mother, married at 16 after two years of high school, is now 22, and is devoted to the children and gives them good care.

2. The father, a career enlisted man in the Coast Guard, is 27; while he had temporary custody during preliminary 
proceedings he showed affection for the boys and gave them good care. . .

The trial court disposed of the custody question on the apparent assumption that children of tender years are ordinarily better off with their mother than with their father. Prior to the amendment of ORS 107.100 in 1961 this as sumption had support in many decisions of this court. . . In each case the decision had been rationalized as one that was best for the children. Frequently since 1961 decisions have favored the mothers. We have no follow-up procedure to indicate whether the se decisions have accurately predicted the future. In each case the trial court has attempted to place custody where the least harm.would befall the children. Juvenile Court cases and change-of-circumstances cases appealed to this court are not a sample from which trustworthy generalizations can be drawn. The trial courts are still confronted with a decisional problem that defies standardized solution. In most cases we affirm out of deference to the superior intuitive position of the judge who sees the witnesses.

We believe that in this case the trial court erred in taking two boys away from a father who was giving them good care and in placing them with the mother where, even with the maximum financial help to be expected of the father, the children are likely to become public wards. We do not mean to imply in this discussion that economic considerations are dispositive in custody cases, but on the other hand, they are not to be ignored.

In Tingen vs. Tingen (1968) the Court, for the first time, laid down some specifics to consider in determining. "best interests of the children, " not strictly: where change is being considered but where any award of custody is made.

In determining the best interests of a child in a custody dispute the court ought to consider all the relevant factors. These, as we see them, would generally include:

1. the conduct of the parties;

2. the moral, emotional and physical fitness of the parties; 
3. the comparative physical environments;

4. the emotional ties of the child to other family members;

5. the interest of the parties in, and attitude toward, the child;

6. the age, sex, and health of the child;

7. the desirability of continuing an existing relationship and environment; and

8. the preference of the child.

Best interest in custody matters should not be determined by isolating one of the se variable factors and relying on it to the exclusion of other factors. Rather, best interest should be determined upon these, and other, relevant factors by: a weighing and balancing process, and not by treating any one of them as a fixed rule or standard.

\section{THE ADVERSARY PROCESS}

Divorce and custody matters are conducted as adversary proceedings, i. e., the husband and wife are opponents and are appearing in a Court of Equity for adjudication of their respective rights and responsibilities. They are asking that the court make fair and equal distribution of accumulated property, of which their offspring are a part. The statutes clearly state that there is to be no collusion, no secret agreement, no conspiracy. If the letter of the law were followed in each instance the court would be faced with the monumental task of arriving at decisions affecting every personal family matter, even where the parties are better able to manage than is the court. 
The divorce process in fact becomes a matter where most of the proceedings are handled "by default" and only a few cases are heard as a contest between opposing parties. In a divorce decree granted by default, the defendant files no answer and the parties have often arrived at a mutually agreeable method of dividing their property, usually with the aid of an attorney. Sometimes they have signed a property settlement agreement which is incorporated into the decree and the provisions thereby become binding upon the parties and are subject to future modification by the court. Only one party is present for the court hearing, or if the other is present he (she) declines to put on testimony. The matter is handled within a few minutes with a minimum of the family problem publicly aired and with a minimum aggravation of already sensitive feelings and injured pride. This method of obtaining a divorce is, despite the law against collusion, encouraged by both the legal and the social work professions because of its obvious advantages.

Where the parties cannot come to some agreement, a court hearing must be held to settle the dispute. This is commonly referred to as a "contested" divorce or "contest." Frequently it is not the divorce itself which is being disputed but possession of one or more of the joint belongings, the most frequent being the children. In this type of hearing both parties are present in court, each represented by counsel; the issues are debated; evidence is presented and 
witnesses are examined. Emotions between the parties usually_run high. Following such a hearing it may be difficult for the parties to deal effectively: with each other over future matters pertaining to the children.

\section{SPECIFIC STATEMENT OF THE PROBLEM}

It is in this emotionally charged atmosphere that a jurist must make a cool and impartial decision "in the best interest of the children. ". There is no clear-cut guide for the court to follow in making these determinations of custody. "Best interest of the children" is at best a vague, ill-defined term subject to the individual jurist's interpretation. About each family situation little is known about the dynamics behind these requested changes, which adds to the vagueness of the already confusing picture facing the jurist. These cases tend to be time-consuming matters, requiring an inordinate amount of court time, perhaps because of their very vagueness.

In the preparation of this review a discussion was held with the Honorable Jean! L. Lewis, Circuit Court Judge, Department 12, who provided information and legal direction and made her library accessible for the gathering of data. Judge Lewis pointed out a major area of uncertainty; if a parent is found to be unfit at the time a modification is requested, yet was exhibiting the same behavior as 
at the time of the divorce, does this or does it not constitute a change of circurnstances? Does a motion based on continuing harmful behavior rather than a change in behavior warrant a change in custody? As one becomes involved in this change process as a researcher, and no doubt as a jurist also, some specific questions arise:

1. Why do some but not all divorcing couples return to the court at a later time in a state of dissatisfaction over the custody arrangements which were originally made?

2. What changes have occurred in the lives of the parties to make change either requested, desirable, or both?

3. What do significant others (grandparents, new spouse, etc.) have to do with this stated desire for a change?

4. How frequently is this merely a continuation of the fight which was begun during marriage, was continued in divorce and is now focused on the only mutual interest area left-the children?

5. What common characteristics might this group have which would make their return to the battle zone predictable?

6. What factors should be taken into consideration in the original action to prevent this kind of later disruption?

7. Are the factors stated in the affidavit accompanying the motion to modify the real reasons or are they designed to conform to requirements of the law? 
8. How often are changes manipulated by the children?

9. What part do finances play in requested changes? (Is the father tired of paying support; is the mother wanting to use the children as a meal ticket?)

10. How often is the is sue actually visitation rather than custody?

11. Should custody be a matter which is determined originally and thereafter remains constant or should custody be a flexible arrangement taking into account the developmental needs of a child? For example, the difference in a boy's need for his father at age 8 and at age 15 .

\section{INTENT OF THE STUDY}

In this research our attention is being directed to this group of people who appear before the court asking for reconsideration of the original ruling as it pertains to custody of the children. Some of these cases will originally have been set and heard as a default matter; others will have been contested from the time of the first filing, perhaps also 'being heard as a contested matter or perhaps only on a prima facie basis (superficial and undisputed evidence is offered). Our attempt is to find any existing common denominators in this group. Are there shared characteristics which make possible early identification of a case that will later return for a rehearing? 
Suggestions will be offered for further study based on the description of these cases which returned for additional litigation during the year 1965. 


\section{CHAPTER II}

\section{REVIEW OF THE LITERATURE}

Little has been written on divorce and the custody of children. The few references found tend to deal with divorce and custody from a statistical or legalistic viewpoint. Judges and attorneys have written of the problems they face in the courts in interpreting and applying the law. People who have been injured or hurt by divorce have written of their experiences. But the body of literature devoted to the psychological impact of the divorce and custody process is limited as reflected in the following survey of the literature.

\section{EFFECT OF DIVORCE ON.CHILDREN}

There is general agreement in most of the literature that divorce has harmful effects on children. However, in our survey:we found that results of the research which has been done in this area are far from conclusive. Most of the sources agree that it is the emotional estrangement, the hostility: and bickering between parents that is the chief causative factor in disturbance in children and not the actual termination of the marriage.

Sociologist Ivan Nye (1968) found in his study that children of 
divorce often manifest fewer signs of disturbed behavior than children from homes where parents remain together in spite of a deteriorating relationship marked by constant quarreling.

Failure to perceive the good adjustment both of children and spouses in many broken homes may stem from a concentration upon the tensions and adjustments which occur at the time of the break. After a period of adjustment, a new equilibrium is established, complicated perhaps by the necessity for each family member to play new and less clearly defined roles, but largely free of the unbearable conflicts of the previous unhappy marriage.

Robert Furlong (1962) points out that one of the greatest injuries divorce does to children is the feeling of rejection it causes. The damage divorce has on children in our culture may be greater than in societies where the extended family lives in close proximity, Furlong feels, and the children of divorce remain with the mother's or father's family, thus experiencing no drastic change in their way of life.

Furlong (1962) makes the point that the bereavement of the child whose home is broken by death. "does not approach the strong, personal sense of guilt which often troubles the children of divorced parents because their mother and father have violated the mores of society."

Furlong (1962) expresses the opinion that the adversary framework used in the courts works well to determine the factual fault between strangers but he feels it is totally unsatisfactory in handling 
the problems of divorce. He states:

The very essence of the adversary proceedings through which a divorce is granted tends to implement the animosity and bitterness of the couple and to increase the probability that they will bear numerous scars as a result of the debate, acrimony, public name-calling and fault-finding, which are inherent in the proceedings by which their divorce is granted.

William Goode (1956) asks the question, "Are the damaging effects of the divorce on the child greater than those of continued home conflict?"'

Goode (1956) points to a study made by Sheldon and Eleanor Glueck attempting to assess the relationship between juvenile delinquency and (a) divorced, (b) widowed, and (c) separated homes, from which he draws the conclusion that ". . the best facts justify our repeated insistence that the relationship between divorce and other behavioral problems of children are not at all clear."

The Gluecks (1950) of the Harvard Law School published what has become a classic study in the analysis of crime causation. Their study compared 500 persistently delinquent boys with 500 nondelinquent boys matched for age, general intelligence, national origin and residence in underprivileged neighborhoods. In assessing the wealth of data they accumulated they could establish no direct causative link between delinquency and broken homes. They did note, however, a higher incidence of divorce $(21.1 \%)$ in delinquent homes than in the homes of the non-delinquent (11\%). 
Morton Hunt (1967) also refers to the study done by the Gluecks in making his as sumption that there is less correlation between delinquency and divorce than there is between delinquency and socioeconomic deprivation.

Quoting again from the Nye (1968) study which involved 780 adolescents in grades 9 through 12 , he found,

As a group, adolescents in broken homes show less psychosomatic illness, less delinquent behavior and better adjustment to parents than do children in unhappy unbroken homes. They: do not differ significantly, with respect to adjustment in school, church or delinquent companions.

\section{CHILD CUSTODY FOLLOWING DIVORCE}

Despite the fact that a pop artist has seen fit to musically record the lament of a non-custodial father ${ }^{l}$, little is to be found in the

1O. C. Smith's recording of Daddy's Little Man, Columbia Record, 1969.

My, my just look at daddy's little man.

Stand there, let me take a look at you.

$\mathrm{My}$, you must have grown about a foot or two since last weekend.

Let's run in and wash your face and hands.

I want to take a little walk and have a little talk,

With daddy's little man.

My, my just look at daddy's little man.

No, I don't want a bit of your mud pie, looks appetizing

But think I'm gonna pass it by this time.

Got a dime right here in my hand.

Want to buy some ice cream and walk down by the stream

With daddy's little man. 
literature concerning the problems germane to the granting or obtaining of custody: and those ensuing after custody has been determined.

Kal and Frumess (1961), attorneys, writing from the legal

paint of view note:

One of the most important problems and that most difficult of resolution when a divorce is sought, and one which produces the most extreme bitterness, is that of custody of the minor children of the marriage. In a majority of divorce actions the defending party; will not contest the divorce itself, feeling, perhaps, that if the marriage has already reached the point of rupture it would be futile to endeavor to keep it together artificially. However, where children are involved and both parties love and want to keep the companionship of those children, a bitter contest will in many cases develop. In this respect, the courts are always extremely scrupulous to keep the interests of the child, the innocent victim of the dissolution paramount.

Kal and Frumess' observation of the interests of the child

You be careful with that ice cream cone,

Or momma's gonna tan your hide.

Speaking of momma, is she all right?

Does she go out a lot at night?

(No, I don't think bullfrogs lie)

Does momma still see $\mathrm{Mr}$. Jones?

You know the man who took you for a ride.

Does she ever look at you and cry?

(Yes, I see the butterfly.)

No, it's just something in my eye.

Remember that muscle you used to tell me about all the time?

Let me see it. Sure thing, look at daddy's little man.

Well I guess you'd better kiss me bye bye now

Time just seems to fly somehow when you're having fun.

I gotta run, I'll call you when I can.

Maybe Sunday I can go to the show with daddy's little man.

Daddy's little man. 
being paramount tends to agree with the manner in which the award of custody has evolved historically.

Ploscowe (1955) feels that divorce has a tremendous impact on the lives of children and that effort should be made by the parents to cushion the shock through proper custody and visitation arrangements.

Dominian (1968) finds,

- . marital breakdown involves more than two adults. The children of such marriages, who did not ask to become either witnesses or participants in some of the bitterest manifestations of human intolerance, antagonism and hatred, pay a very. heavy price. They are deprived, through no fault of their own, of their right to feel secure and loved by the authors of their life, and are frequently manipulated or pushed to take sides with one party. The much desired and needed positive image of both parents is distorted beyond recognition by the real or imaginary grievances of one of them, which the child cannot understand or evaluate. Their loyalty is torn beyond endurance when, in committing themselves to either parent, they have to identify themselves with one point of view at the expense of the other, only to discover many years later the dubiousness of their position and at times the complete falsity of the attitude which they: were trapped into adopting.

Bernard J. Coughlin, S. J. (1968), Dean, School of Social Service, St. Louis University, recently published an article discussing the rights of children in divorce. He quotes from a United States Supreme Court Decision in which Justice Hugo Black opined:

Unfortunately, experience has shown that the question of custody, so vital to a child's happiness and well-being, frequently cannot be left to the discretion of the parents. This is particularly true where . . . the estrangement of husband and wife beclouds parental judgment with emotion and prejudice. 
Despert (1962), a child psychiatrist who has seen many chil-

dren in treatment coping with the meaning of divorce, points out that in recent years the nuclear family tends to be smaller and more isolated than in years past. She feels that this has a strong effect on children's emotional needs when there is a divorce and ensuing custody, battle:

Instead of many adults from whom to draw their support and in whom to invest their love, they are now likely to have only two.. . if indeed they are lucky enough to have both. Fewer children in the family itself . . must develop within family a compensating intensity in.... . relationships.

Glasser and Navarre (1967) also stress the fact that in our present society the increasing isolation of the nuclear family focuses the emotional needs on this small group and intensifies the relationships within it. When divorce occurs, the intensity of the relationship between the child and the custodial parent is increased.

The loss of one parent removes a large portion of the structural balance and intensifies the influence of the remaining parent on the children, while possibly limiting the ability of this parent to withstand demands made upon her by the children. There is also a tendency for any family member to transfer to one or more of the remaining family members the demands formerly filled by the absent person. There would seem to be a danger in the one-parent family that:

1. The demands of the sole parent for the fulfillment of individual and emotional needs normally met within the marital relationship may prove intolerable and damaging to the children, who are unable to give emotional support or to absorb negative feelings from this source, or 
2. The combined needs of the children may be intolerable to the emotionally unsupported solitary parent. Since the emotional requirements of children are very likely to take the form of demands for physical attention or personal service, the remaining parent may be subject to physical as well as emotional exhaustion from this source.

From a legal standpoint, Robert W. Hansen (1966), Circuit

Court Judge, Milwaukee County Family Court Division, feels a child should be thought of as a third party beneficiary in the marriage contract and the state should provide someone to represent his interests at the time of divorce. He quotes a Bill of Rights of Children adopted by a group of judges in Milwaukee, Wisconsin which contains several points relating to custody: the right of the child to day-byday love, care, discipline, protection by the custodial parent, the right to know the non-custodial parent, etc.

Hansen and Goldberg (1967) in an article on the family court make a plea for clarification of the role of the social worker in custody matters. He feels that too often in the past the social worker has operated primarily as an investigator and that the social worker has a great deal more than this to offer.

As a child welfare expert, he brings to the court a keener assessment of the child's needs and the alternatives in custody placement than would otherwise be available. In addition, by giving his recommendations at the hearing, he provides a focal point for testimony and discussion around which the custody of a child may be determined. This tends to expedite matters, so that a more prompt determination of custody may be arrived at. In his relationship with the parents, he adds to their understanding of the child's needs, and he is in a position to give them emotional support and guidance. 


\section{REASONS FOR DIVORCE}

Truxal and Merrill (1953) note that it is difficult to assess the real reasons for divorce from the legal files. They state:

There is no way of knowing how many divorces are granted on fictitious and how many on bona fide grounds. The nature of divorce proceedings renders such knowledge impossible to obtain. Any conclusions based on the number and percentages of divorces granted on the various legal grounds, therefore, should be made with caution. The behavior measured by such data is of a special legal character, which often bears only an indirect relationship to life. The "real" reasons for the disorganization of the family by divorce are the tensions and conflicts existing between its members. . . and often bear only a remote relationship to the legal grounds on which the divorce is granted.

Meyer Elkin (1962), Supervising Conciliation Counselor, Conciliation Court of the Superior Court of the County of Los Angeles, decries the adversary principle and pleads for a socio-psychological approach to divorce. He declares that,

Present-day:divorce courts, hampered by archaic and unrealistic laws, tend to aggravate an already disturbed situation instead of providing a protective and healing atmosphere for troubled families coming within their jurisdiction. In effect, a divorce decree is a family death certificate declaring that the marriage is deceased. Usually the real reasons for a divorce are not made known in the statement of alleged legal reasons; rather they are to be found in the character defects and personal inadequacies of one or both partners.

In an article appearing in the Portland Oregonian (1969) Michigan Judge Stewart A. Newblatt and three other Genesee County Circuit Judges responded to the question, "What are the real reasons for divorce?" asked by: Friend of the Court Robert W. Standal, with 
the following list:

1. The excitement of a new love interest.

2. The monotony of looking after a family that grew too fast or was started when the parents were very young.

3. Money, when it's spent faster than it's earned.

4. Estrangements that sometimes come when a wife goes to work, meets new people and finds new interests.

5. The problems arising when husband and wife have different social or educational backgrounds.

6. Prosperity, which leads some men to feel there will be no strain in taking new mates while making support payments for the children of their first marriages.

Judge Newblatt is further quoted as saying; "The real reasons (for divorce) never come out in a courtroom. The courts are really bad places to find out."

\section{STATISTICS OF DIVORCE}

The statistics of divorce indicate a problem of ever-increasing proportions. Nationally, the divorce rate per 1,000 population has risen from 2. 3 in 1963 to 2.7 in 1967. The 1967 total of 534,000 divorces granted represented an increase of $8 \%$ over 1966 (Statistical Abstract of the United States, 1968).

The Bureau of VitalStatistics (Portland, Oregon) recorded for the State of Oregon that the total number of divorces granted rose from 6,219 in 1965 to 8,258 in 1968 , an increase of $32.8 \%$. The 
total number of children affected by the divorces totaled $7,671^{1}$ in

1965 and $9,863^{2}$ in 1968 , representing an increase of $28.5 \%$.

In Multnomah County, the site of this study, the population increased according to the Bureau of Vital Statistics estimates by only 700 persons between 1965 and $1968(555,000$ to 555,700$)$, an increase of $0.1 \%$. Yet the number of divorces increased by 572 from 1,957 in 1965 to 2,529 in 1968 , representing an increase of $29.2 \%$.

\section{DETERMINATION OF CUSTODIAL PARENT}

\section{Guidelines Used by Courts in Determining}

Best Interests of Child

As pointed out in the introductory chapter "best interests" is a vague and ill-defined term though Oregon Courts have received some guidance through the Oregon Supreme Court Decision, Tingen vs. Tingen (1968).

In the literature several authors discuss the meaning of this term. All of the references cite the welfare of the child as the deciding factor in the determination of the custodial parent. But the welfare of the child is not always a simple matter to determine.

${ }^{1}$ does not include 458 divorces where there was no reponse to the question, "How many children affected by this divorce?"

2 does not include 584 divorces where there was no response to the question, "How many children affected by this divorce?" 
Mayer (1967) says,

The crucial determinant in custody dispute is the welfare of the child. What will be best for the child? What will best contribute to his development? What will give him the opportunity for the "pursuit of happiness"? These are the primary questions before the court.

He lists five criteria considered:

1. Relative interest of each parent in child.

2. Their ability to take care of child/children.

3. How much time they must spend away from child at work or elsewhere.

4. Physical health.

5. Mental condition.

Mayer (1967) also finds the child's wishes are relevant, particularly if the child has attained some degree of maturity.

Ploscowe (1955) cites eleven factors which the court may weigh in determining the child's best interest:

1. relative fitness of each parent

2. responsibility of that parent for the dissolution of the marriage and the divorce

3. type of care each parent offers

4. environment in the proposed home

5. relative economic and social advantages to the child from being: with one parent or the other

6. age, sex, health of the child

7. presence or absence of relatives to assist in caring for the child 
8. relative ability of the parent to take care of the child financially

9. affection of the child for the parent and of the parent for the child.

10. preference of the child

11. presence or absence of facilities for spiritual or religious instruction

But even with these guidelines, Ploscowe (1955) feels, there are too many unknowns and uncertainties, and judges have wide discretion. The final result in contested cases of custody, therefore, ". . may depend as much on the personality of the judge as the facts of the case."

Despert (1962) sums up the feeling frequently expressed in the literature that if the best interests of the child were paramount to all the participants in a divorce action, the problem of custody would never come before the court. The parents would not need the court to resolve their differences. The parents, together and with the help of counseling agencies, clinics, or private consultations with a psychiatrist would find the best solution--that is, best for the child. As previously noted, best interests of children are often difficult to determine but Ploscowe (1955) found that there were certain guides to which courts generally adhered but from which they may depart. He enumerates eight general guidelines:

1. Mothers are generally preferred in custody disputes particularly where very young children are involved. 
Charles Metz (1968), a layman obviously bitter from his experience with the courts, has found this to be true and it forms much of the basis for his book designed to help men obtain their rights in "courts designed for women."

In an article from the Seattle Times (1969), Dr. E. Lynn Waldrip, : a psychologist and an unsuccessful contender for the custody of his five-year-old daughter, believes the courts to be prejudiced against men in custody and too hasty in making custody awards to mothers. Waldrip is quoted as saying:

There iis ample evidence in my own clinical experience, the experience of my colleagues and hundreds of testimonies from citizens as to the errors being made by the present handling of custody, but to my,knowledge there has been no research done on this.

In the same article from the Seattle Times (1969); Mrs. Alice Y. Thomas, Acting Administrator of the King County Family, Court, feels that while she and her staff do not begin their studies with a fixed idea of which parent should have custody, they try to ascertain which parent potentially can give the most to the child. This assessment is not only in material terms but provision for the emotional well being of the child is considered. She states, ". . . we think of the future--what the circumstances likely:will be in the next ten years." Mrs. Thomas said in most instances the family court does determine that the mother shall have custody.

Kal and Frumess (1961) state that mothers are given 
preference in custody cases involving small children or older girls.

Ploscowe (1955) notes that historically there was a decided preference for the father in custody disputes as pointed out in the introductory section on "History of Divorce." However, he goes on to say that presently either by statute or court decision this preference for the father has been largely eliminated.

Both parents are deemed to be the natural guardians of their children. Both parents are legally entitled to the custody of the child. Both parents are on a plane of equality in any custody dispute concerning the child.

Despert.(1962) agrees that courts favor the mother when the child is young but that beyond a certain age which she places at seven to nine years, a boy needs his father.

2. An award of custody is usually made to the successful party in a divorce action.

Kal and Frumess (1961) agree. Mayer (1967) states that the "fault" criterion is extremely dangerous and should play little role in the determination of custody. Metz (1968) cites the fact that most often the wife will initiate the divorce proceedings and then invariably obtains custody of the children. He encourages men to initiate divorce proceedings and feels they thereby enhance their chances of obtaining custody because of the courts' predisposition to award custody to the successful party. in the divorce action.

3. The preference of a child for a particular parent is not 
conclusive in a custody award.

4. Parents have a superior right to children over grandparents or other relatives.

Mayer (1967) says that there is no binding rule that a child must go to the parents, this in accord with the doctrine of giving top priority to the welfare of the child.

5. Courts do not like divided custody arrangements where the child spends half of the time with mother and half of the time with father, nor do they look with favor on splitting up children.

Mayer (1967) finds that split custody has failed to provide a satisfactory solution to custodial disputes. He states:

It appears that it is necessary, both psychologically and otherwise for the child to have "one home" rather than two. Of course, this should not affect frequent visitation by the other parent, which should be granted in all but the rarest instances.

6. Courts are reluctant to permit children to be taken out of their area of legal jurisdiction.

7. A court may deem a parent unfit to bring up a child and deny a parent the right of custody because of his unpopular political beliefs or unconventional religious views.

Despert (1962) agrees, stating that,

- . a parent whose way of life deviates from convention is not fit to rear a child (convention being of course defined by the custom of the community plus the moral code in which the judge himself was reared). 
8. The courts usually insist upon a right of visitation for the parent deprived of custody.

\section{MODIFICATION OF DECREE; CHANGE OF CUSTODY}

As established in the Bogh vs. Lumbattis Oregon Supreme Court Decision (1955) a change of circumstances is essential to obtain a modification of the divorce decree in regard to custody. A review of the literature confirms the necessity of defining "change."

$\mathrm{Kal}$ and Frumess (1961) note that while most states require a substantial change of circumstances of the parties to warrant modification, some states say that a slight change is sufficient. Usually, only those facts occurring after the date of the divorce decree may be heard in a modification hearing. However, the court is not strictly limited as in other types of cases and can hear any evidence which will result in benefit to the child.

Regarding post-decree modifications of custody, Despert (1962) comments that,

- . the impression is inescapable that parents who reopen a custody agreement in court are generally fighting the same battle with each other all over again, with the helpless child as the pawn.

Is it possible for custody arrangements at the time of the divorce decree to remain satisfactory over a long period of time?

Despert (1962) thinks not. She states, "In recognition either of 
the court's inability to solve the tangled human equation, or of the unpredictability of human beings, the custody granted by the court is almost never permanent."

Thomas L. Lodge (1962) points to some of the same factors involved in changing custody from one parent to the other as were discussed in Chapter I. He stresses the fact that "circumstances" which justify: a modification of decree are not governed by fixed standards; each case must be given individual consideration. $\mathrm{He}$ lists the following factors which may influence the court's decision:

1. Unfitness of the custodial parent.

While it is not necessary to prove unfitness of the custodial parent, the party seeking a change of custody must demonstrate a definite deterioration in the conditions which were present at the time of the original custody: award.

2. Improvement of the non-custodial parent's position.

Although changes which show the petitioning parent's improved ability to care for the child are not sufficient in themselves to constitute a change in circumstances, they may influence the court as a part of the complete picture.

3. Care given children by the custodial parent.

Health and school progress of the child, how he relates to peers, and other considerations are made by the court in forming an overall picture and coming to a decision in regard to the best 
interests of the child.

4. Conduct and condition of the parties.

Behavior on the part of the custodial parent which indicates unstable or consistently promiscuous behavior may constitute basis for modification.

5. Home to which the child would go after a change in custody. Parent seeking custody must demonstrate that the home to which the child will go is a stable one in which the child can grow and develop.

6. Obstruction of visitation rights.

Usually this in itself is not sufficient reason to warrant removing the child from his custodial parent, although the court may modify visitation procedure.

7. Preference given mother.

The Oregon Courts usually give custody to the mother when children are "of tender years." What the father considers moral unfitness must be shown to be of sufficient magnitude to actually be injurious to the child!s welfare, if a change of custody is to take place. The court's attitude towards the mother, says Lodge, places the father in an unfavorable position in the legal proceedings and this is true despite the 1961 amendment (ORS 107.100) providing for equal consideration of both parents. Lodge (1962) feels that this change will not cause the court to discontinue to give preference to the 
mother but that courts

- . will phrase their justification for the decision in general terms of the welfare of the child, rather than upon the theory that children of tender years should be awarded to the mother for the "sole reason that she is the mother."

8. Preference of the children.

If the child has reached the "age of discretion" his preference may be considered. The court gives little consideration to the choice of a younger child since it is felt that he may not be able to express his true feelings. 
CHAPTER. III

METHOD

\section{FORMULATING THE STUDY}

It was obvious from the outset that our subject was one for a long term program of study. The important questions pertaining to divorce action cannot be answered without a series of studies, of which the early ones would be exploratory. A number of criteria for this beginning study: were specified. The most important ones require that the study:

1. Relate to some major concepts of the adversary proceedings in order to focus the study: within some larger framework and provide a basis for developing a series of studies in the particular area of "after divorce."

2. Involve some kind of formulations that are reasonably explicit so that the time required for initial conceptualization would be minimized.

3. Focus upon an area about which there is a lack of adequate information and in which the subject matter of the study would not encounter already deeply formed convictions about the process. 
4. Require a minimum of assumptions about the study and obtain data which would bring to the fore or support what we know actually does occur during and after divorce.

5. Be of use to the court in its further handling of the se situations.

It is our belief that the study meets these criteria and fulfills group goals by leading the way in describing and perhaps improving the legal program of the court to better meet people's needs. Group discussion brought out different aspects of the adversary process that needed study, such as points at which theory is weak or lacking, crucial gaps in: information, etc.

Early: suggestions included an interview with divorced partners and with the judges of the Circuit Court in order to help fill in crucial gaps in information and to gain a better understanding of the legal process. Group consensus was that interviews with divorced couples would necessitate dealing with three specific problems: (a) they would demand more time than we would be able to devote to them, (b) there would be difficulty in locating people since they may have remarried or left the city, and (c) it might be difficult to obtain the real reasons people return to court to modify the divorce decree. 


\section{SOURCES OF INFORMATION}

The thesis group believed that information obtained in interviews with the three Circuit Court judges would be of value in this study. Such information could cover a broad area and again group consensus considered the limited time which likely would not permit sufficient follow through. Future studies should include knowledge contributed by the court since it is the judge who makes a decision at the time of the divorce and again later when requests for modification of decrees are made.

One productive source of information for any study is the knowledge of court social workers who often make family studies which assist the court in reaching decisions in contested cases. Both our research advisor and one of the group members are employed by this court and have given valuable information found in the study. Much of the ground work was laid by them and gave a basis from which we began the study. Also, two other members of the group had first year field placements in the social agency attached to this court and gained not only experience but many, insights into the workings of the Court of Domestic Relations and some of the problems with which the court is faced. 


\section{AIMS OF THE STUDY}

We hoped to determine whether families share common characteristics which would allow for identification of potential problem families at the time of the original divorce decree; factors that bring parents into conflict with each other over the children; the sociolegal circumstances under which the court awards a change of custody; and the effects of the court's ruling on the two parents.

The method of collection was that of systematic case analysis. It was early agreed that case records would constitute the source of information about the study:area. Limitations are necessarily imposed on any research design by the choice of source material. The decision to use case records was prompted by the greater economy of time with this method.

By studying only the legal files our attention was directed almost solely on the adversary proceedings. One limitation of this method is that our sample is based upon cases where custody was disputed; it does not include cases where custody is agreed upon by the divorced parents. Other limitations discovered during the study were:

1. Legal files are incomplete.

2. Winning attorneys, who are responsible for filing legal documents, do not always comply. 
3. Not all docketed cases are heard.

4. Some motions are denied.

The schedule with code sheet was completed in its first form in May. A pretest was made and the schedule revised to (a) determine the variables, the known errors and/or omissions in the files; (b) provide opportunity for group members to become more familiar with the population to be studied and with the court environment; (c) give some experience in techniques, etc. to be used in research, and (d) show what kinds of information could be most useful to the study. After the third and final draft the group made a trial test to determine the time involvement for our sample.

In selecting our sample we chose those cases specifically labeled "custody" by the docket clerk. We took them from both the judge's weekly calendar and from the clerk's motion docket." All motions set for a hearing. which specifically pertain to the issue of custody during 1965 are included. The final sample includes 92 cases.

\section{THE COURT OF DOMESTIC RELATIONS} IN MUITNOMAH COUNTY

In the Circuit Court of the State of Oregon for the County of Multnomah, three departments out of the total sixteen departments have been designated to constitute the Court of Domestic Relations. 
In this composite court, consisting of three judges and their staffs, are heard, with rare exceptions, all matters relating to divorce, custody, visitation, child support, alimony and adoption.

As previously described, Oregon law provides for continuing jurisdiction within the Circuit Court over custody of the children of divorced parents once jurisdiction has been established. This means that if future changes create dissatisfaction with a past order made by this court, a remedy may be sought by returning to that same court for redress. Either the same or a different judge may hear and rule on the problem presented. This ruling is always subject to review by the Supreme Court if an appeal is taken.

A problem is presented to the court in the form of a motion to modify an existing order; i. e., one of the two parties makes a legal move requesting a change. This is done with the aid of an attorney. There is a set procedure by: which an attorney schedules his client's grievance for a hearing through the Domestic Relations docket clerk. Due to time variances a particular case may be set several different times before it is actually heard by a judge.

Our sample was taken from the group of motions scheduled for hearing during the year 1965. Court activity is recorded by the docket clerk and kept in separate folders by month. Motions set are entered on one of two different lists, the weekly court calendar for each judge or the clerk's motion docket, according to the amount 
of court time requested.

\section{COLLECTION OF DATA}

In collecting data: we elected to follow the order by which divorce action involving custody proceeds through the court. All cases do not necessarily go through each step. There are three distinct points at which the court can appropriately consider custody:

1. After the initial filing of action but before a divorce is granted; termed pendente lite proceedings.

2. At the time the divorce is granted; in the establishing of the divorce decree.

3. Any time following the granting of the decree and during the minority of the children; based on a motion by either parent to modify the decree.

Each step in divorce and/or custody proceedings is accompanied by the filing of an appropriate set of papers. This legal "filing" is the instrument which sets the court machinery in motion and also makes minimal information available to the jurist hearing the matter. (The rest of the information upon which the jurist bases his decision is presented verbally.). Each of these sets of papers contains specified information, such as the complaint listing the names and ages of the children. As the result of group discussion we agreed on the items of information which we would record from 
each of these sets of papers. To record this information, we drew up a guide or reading schedule (see Appendix A) by which we could collect the same information in the same way from each individual case.

After developing the reading schedule a pretest was done in which each member of the group read at least one case. We then met as a group, discussed the problems encountered, clarified misunderstandings and areas of uncertainty and made minor alterations in the schedule before proceeding with work on the remaining cases. The reading was done on an:individual basis with no group action again until this segment of the study had been completed.

\section{EXPLANATION OF THE READING SCHEDULE}

\section{The Complaint--Item I}

A case is begun with the filing of a Complaint in Divorce or Complaint in Equity. Either term may be used. This complaint contains the case number, date of filing, the plaintiff's and defendant's names and sometimes the ages. At this point the party hereafter to be called "plaintiff" is determined. It may be either husband or wife, whichever has filed this original complaint. The other party is hereafter entitled "defendant" throughout the case.

The complaint also contains the date and place of the marriage, 
from which data we computed the length of the marriage. The children born to the marriage and their ages are listed as are the legal grounds on which the divorce is being sought (refer to Chapter I, pp. 14-15). These general "grounds" are supplemented by the recital of particular offenses relative to the individual case. In the collection of data we listed the particulars on the reading schedule by code number (see Appendix B).

The complaint further contains the plaintiff's allegations to the court relative to the fitness of each party to be awarded custody of the children and usually contains a specific: request as to which parent shall receive this award, or a request that the custody be divided and how.

Some mention about visitation is usually made in the original complaint. If not, we checked "NR" (not recorded); if the request was for reasonable visitation, we checked " $R "$ "; we checked " $D$ " if the request was to limit visitation to one day at a time; "O" was checked when a suggestion for visitation involved two or more successive days necessitating the children remaining away from home overnight. We included a category for any special arrangements suggested.

The complaint usually contains a specific request for child support and sometimes for alimony. We recorded this by amount per child per month. Alimony was recorded according to the 
individual request: in dollars per month, a lump sum, legal fees.

A subjective judgment about property. was made according to whatever information was provided in the complaint. If no mention was made of property, "NR"' (not recorded) was checked; "NL" was checked when there was none or when it was very limited; "M" (moderate): was checked when the amount of property fell in a middle range, such as when the parties owned or were purchasing a house, car and furniture; "C" (considerable) was checked for any. amount above that already mentioned, such as a house, car, furniture and boat. A further subjective judgment was made about the plaintiff's request to the court for division of this property; i. e., whether plaintiff was asking for all, whether it was requested that defendant receive all or at what point on the scale between these two extremes the request for property division seemed to the reader to fall.

\section{The Answer--Item II}

The Answer to the complaint, if filed, is done so by the defendant and may be done so separately or in conjunction with a crosscomplaint. An answer only admits or denies certain allegations made in the complaint and asks for nothing. Therefore, we recorded only the date an answer was filed.

\section{The Cross-Complaint--Item III}

The Cross-complaint is the legal vehicle by which the 
defendant states his case and makes his plea for that which he believes should be awarded to him. Additional information available includes the date the cross-complaint was filed and the grounds, both general and particular, on which the defendant is requesting the award of the divorce. The defendant's request regarding custody, visitation, support, alimony and division of the property was collected in the same manner as was done for the plaintiff. The defendant's plea may be the same as or different than the plaintiff's plea in any or all of these categories.

Show Cause Motion for Action

Pendente Lite--Item IV

Due to the legally required time lapse between the date of filing and first possible date for a court appearance on the divorce matter itself, some situations require the settling of is sues by court order during this interim. (The law requires an interim of 90 days between the date of filing and the date the decree can be granted. Due to a change in this particular part of the law in 1965 , this time lapse was only 60 days until September, 1965; thereafter, 90 days.) This is the first opportunity the court has to make an award of custody and if done, will be on a temporary basis. Either party may file action demanding that the other party appear in court and show cause why the court should not make an order relating to a specifically stated issue, such as support during this interim. We recorded 
which party filed this motion and the date; the information about custody, visitation, support and alimony, as was stated in this motion was recorded in the same manner as had previously been done. In addition we included any requests made for one party to be restrained from harrassing the other, any request made for one party to remove himself from the home, any request made for attorney's fees as they would pertain to this isolated piece of court action only.

Answer to Show Cause Motion--Item V

If an Answer to a show cause motion pendente lite was filed, we recorded the date of filing only since an answer does not ask for anything, but rather simply denies or makes a statement in defense of the filing party's behavior.

\section{Order Pendente Lite--Item VI}

There are two means by which a pendente lite order can be entered: (a) one or both parties would be required to appear before the court for a determination of the issues, or (b) the parties could reach an independent agreement and stipulate to the entry of an order based on their agreement without the necessity of a court appearance. Any order at this point would pertain to the show cause motion which had been filed and would not affect the original complaint even though the items ruled on by the court might be the same.

In collecting information we recorded the date this pendente 
lite order was filed; to whom the award of temporary custody was made--plaintiff, defendant or whether and how an award of split custody may have been made; the order regarding visitation (not recorded, reasonable, daytime, overnight, special); the amount of temporary support ordered; any alimony ordered; any order restraining the parties from harrassing each other; any order to move from the home; any order regarding attorney's fees. If this order was signed as per stipulated agreement of the parties we noted "STIP" and the date in the margin. At this point a case might be referred to the Family Consultant's Office, a social agency adjunct to the court, for the purposes of a social study relating to an award of custody in the best interests of the children. If such a study was ordered at this point, we so noted it at the end of the schedule.

\section{Motion to Modify the Pendente} Lite Order--Item VII

The potential for a change in circumstances is present both before and after the granting of a divorce decree. Therefore a motion may be made to modify any temporary order. When this happened we noted it in this section and recorded the date such a motion was filed and by whom; what the changed custody, visitation or support plea was; and the particulars about the reason necessitating the change. 
Order Modifying Pendente Lite

Order--Item VIII

Such an order could again require an appearance by one or both parties or could be based on the stipulated agreement between the parties. We recorded the date and the order as it related to custody, visitation or support. In the margin we noted if this was done by stipulation and the date.

\section{The Divorce Decree--Item IX}

The Decree is the order which dissolves the marriage and divides the property. It is the second major point at which the court can consider the matter of custody. The action taken is based on information provided in the complaint, answer and cross-complaint and takes into consideration any pendente lite action which has transpired. If the divorce is being heard as a default matter, testimony is officially recorded by a court reporter, transcribed and becomes a part of the legal file. If the action is contested, the litigation is duly recorded but not transcribed and therefore does not become a part of the legal file. We recorded the date of this decree and the time lapse, calculated in months, between the filing of the complaint and the granting of the decree. We recorded the custody disposition made (plaintiff, defendant or split and how); the visitation ordered (not recorded, reasonable, daytime, overnight, special); support in amount per month per child; any alimony granted. 
If attorney's fees were not asked for we circled n. a, f. on the reading schedule. We noted how much had originally been requested and by whom and then noted how much had been awarded and to whom. A subjective judgment was again made about the amount of property possessed by the parties with a further subjective judgment made about where on the continuum between "Plaintiff all

Defendant all" the actual court award of property fell.

\section{Motion to Modify Divorce Decree--Item X}

This is the third place where the court can consider the matter of custody. For the court to consider any change in the decree, a change of circumstances must be shown by the party requesting the modification. (See Chapter I, pp. 16-17.) In the affadavit accompanying the show cause motion certain facts must be spelled out providing a basis on which the court directs the opposing party to appear and show cause why the decree should not be modified. We recorded the date of filing of the motion, by: whom and the time lapse in months between the granting of the decree and this move for a change. We noted what change was requested--custody, visitation, support or alimony--and what the changed circumstances were which necessitated a review of the decree.

\section{Order Modifying Divorce Decree--Item XI}

We noted the date of this order and the time lapse in months 
between the date the motion was filed and the date of the amended order; we noted what the change was.

Family Consultant Activity--Item XII

Marriage counseling services are available through the court. In the event divorce action had already been filed at the time these conciliation services began a Minute Order advising that counseling was in process was entered in the divorce file. In collection of data we recorded the known cases on which conciliation services were given by date the service began.

Any Family. Consultant activity in a case was always known and was so noted on the reading schedule by date. There were other points than at the time of a pendente lite order when Family Consultant activity could be ordered. Special proceedings to instigate this service were not necessarily, required, but the date such service was instituted was always noted on the cover of the legal file.

Other

This section covered any legal activity not specifically covered by the above eleven sections. If there was an answer to the motion to modify the decree, it was so noted in this section since space had not previously been provided.

We found a number of cases in which more than one action to modify the decree was brought. Since no space had been provided on 
the reading schedule to record more than one motion, any additional motions were noted in this section with the same information collected as was collected in the original motion to modify.

During the summer months of 1969 the group met individually to complete the schedules. After completion the group again met as a whole to review the schedules to be certain all pertinent items were answered. Some information had been omitted and although these schedules were included in the sample, it is noted there were no modifications made.

\section{SUMMARY}

The principal aim of this study was to find common characteristics, if any, in the group of people who returned to the court for resolution of a continuing problem following dissolution of the marriage. We have no knowledge of related studies previously undertaken and elected to describe these families. The cause of continuing dissatisfaction in this group is generally unknown. We chose to review the legal files of divorce action in an endeavor to determine whether common denominators did in fact exist. 


\section{CHAPTER IV}

\section{FINDINGS}

\section{THE SAMPLE}

In selecting our sample we chose those cases specifically labeled "custody" by the docket clerk. We took them from both the judges' weekly calendar and from the clerk's motion docket. All motions set for a hearing, which specifically pertained to the issue of custody during 1965, were included.

The original sample selected totaled 197 cases. Through the application of the reading schedule to these cases, a number of inappropriate cases became apparent. The research director then individually reviewed each case for its relevancy to the study, prior to making it available for reading. Eighty-four such cases were so identified and deleted from the sample, leaving a reduced sample of 113 cases. Case inspection revealed that the se 84 cases were scheduled for the purpose of obtaining an interim order pending actual divorce litigation and were not motions to modify an already existing order.

In March 1965 an administrative decision was made to change the terminology on the clerk's motion docket. Instead of using the 
term "pendente lite" to describe those cases in which an interim order was requested, the more specific terms of "temporary custody" or "temporary support" were used for easier identification of the problem by the judge at the time of the hearing. During January and February 1965, some cases were termed "pendente lite" and were not included in our sample. From March through December 1965, after the change in terminology, these same kinds of cases were inadvertently included in our sample because of the key word "custody." This change made during 1965 was unknown to us when the original sample was selected.

Of the remaining 21 cases, 14 were read and included in the sample at that time, before it was discovered that they had been inappropriately identified. Two additional cases were mistakenly identified and were erroneously included in our sample of 92 cases, before their lack of relevancy: was noted. Four cases were unavailable for reading (one at the Supreme Court, one at the Juvenile Court, and two missing) and are not included in the sample. One additional case was misidentified, which was a case of legal separation, rather than divorce. The final sample selected for study was 92 cases.

\section{PLAINTIFF AND DEFENDANT}

In our sample of 92 cases, the divorce was initiated by the 
husband, as plaintiff, in 34 cases, or $37 \%$ of the sample. The wife initiated, as plaintiff, in 58 cases, or $63 \%$ of the sample. In only 28 of the case records were the ages of both the plaintiff and the defendant recorded. At the time of marriage the male parties ranged in age from 17 to 44.5 years, with a mean age of 23.2 years and a median age of 21.2 years. In twelve cases the male parties were under age 21. The female parties ranged in age from 15 to 43 years with a mean age of 20.1 years and a median age of 18 years. In ten cases the female parties were under the age of 18. At the time of the divorce, the male parties ranged in age from 19 to 48 years with a mean age of 31.1 years and a median age of 29 years. The female parties ranged in age from 17 to 44 years with a mean age of 28.1 years and a median age of 25 years.

Table I records the places of marriage and the distribution of the cases according to the place of marriage.

TABLE I

PLACE OF MARRIAGE

\begin{tabular}{|c|c|c|c|c|c|}
\hline \multicolumn{2}{|c|}{ Oregon } & \multicolumn{2}{|c|}{ Washington } & \multirow[t]{2}{*}{ Other } & \multirow[t]{2}{*}{ Total } \\
\hline Portland & Other & $\begin{array}{c}\text { Vancouver, } \\
\text { Stevenson }\end{array}$ & Other & & \\
\hline 27 & 5 & 35 & 6 & 16 & $89 *$ \\
\hline
\end{tabular}

*Three cases listed no place of marriage. 
The number of marriages in the Vancouver-Stevenson, Washington area exceeds that of Portland. An explanation for this is that prior to 1965 it was possible to marry in these Washington cities without the usual three-day waiting period and the requirement of a blood test, which was mandatory in the State of Oregon.

Figures 1 through 6 provide a graphic representation of the lengths from the date of marriage to the various legal actions and the time lapses involved from one court action to another.

Figure 1 shows that in the sample studied nearly one-third of the marriages ended within the first five years. This would seem to correlate with the national trend, although the United States Bureau of the Census (1969) does not record this. Dominian (1968) states that although statistics differ, ". . . they are all in agreement that divorce has a high incidence in the early years of marriage, which appears to be the critical phase."

Speculation as to reasons for this are as follows:

This is the period of initial adjustment stress. It is the time when the young marital partners seek to fuse identities, in the Erikson (1950) sense, and frequently find that they are not sufficiently mature for this kind of intimacy and responsibility. They may lack, in Erikson's words,

. . the capacity to commit themselves to concrete affiliations and partnerships and to develop the ethical 


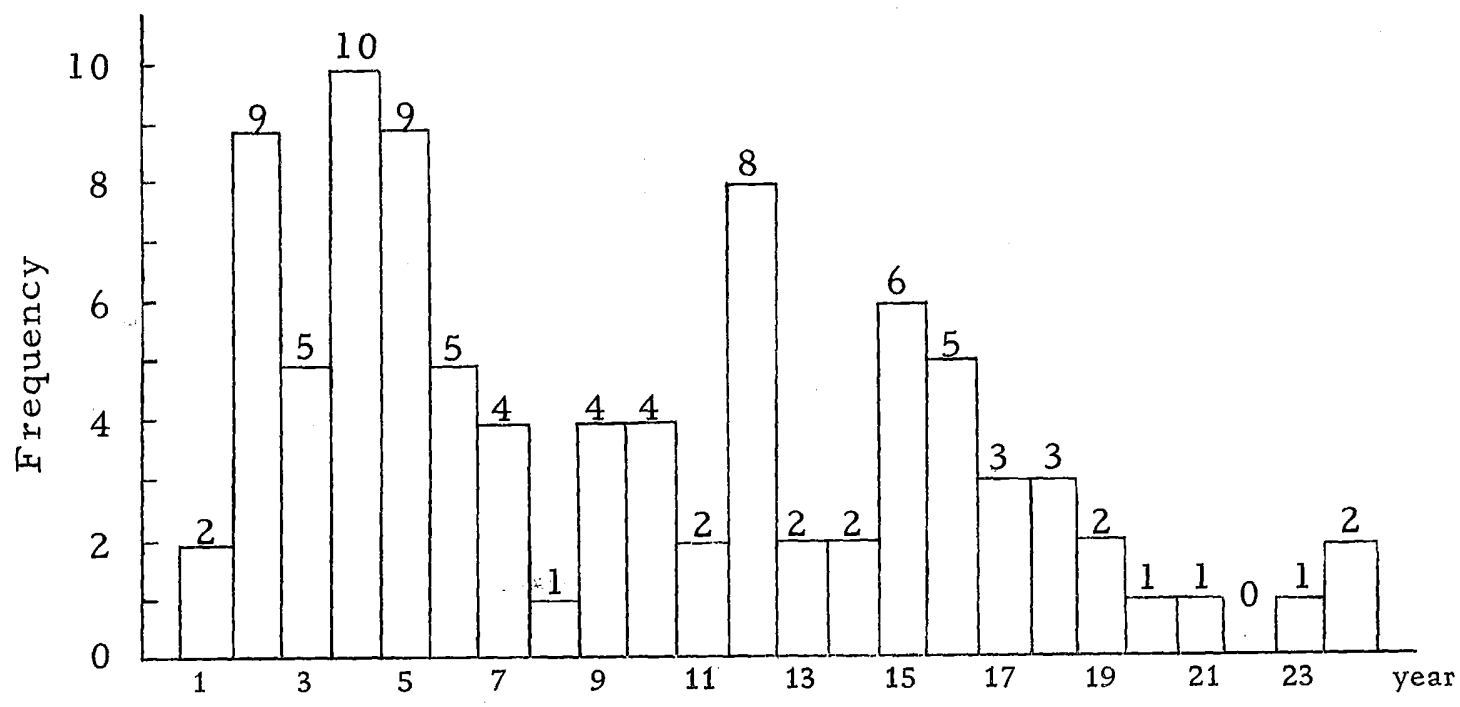

Range: 3 months to 24.2 years

$\mathrm{N}$ : 91 (no original date of marriage in one case

Mean: 9.0 years

Median: 8.1 years

Figure 1. Length of marriage to filing of divorce complaint

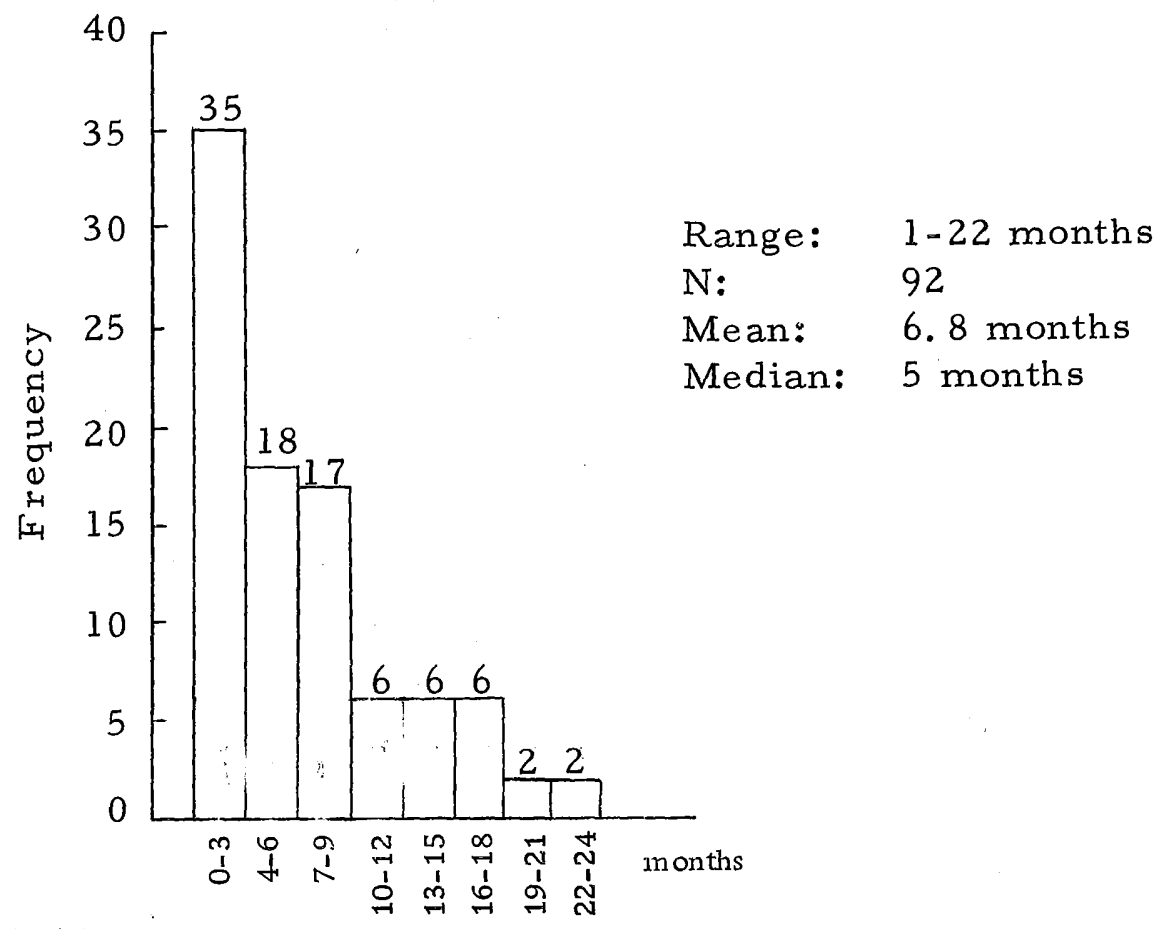

Figure 2. Time lapse between filing of complaint and decree. 


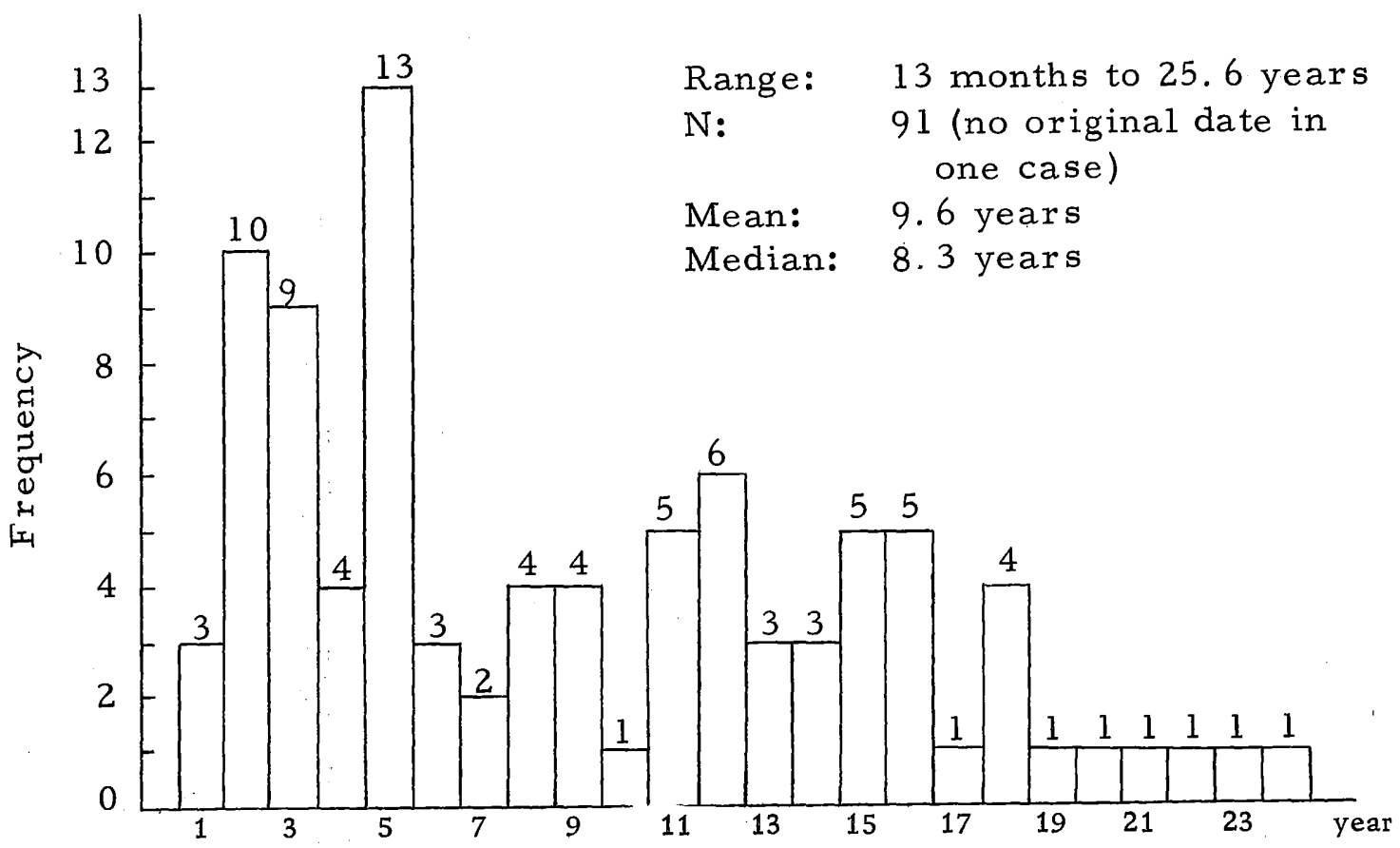

Figure 3. Length of marriage to divorce decree.

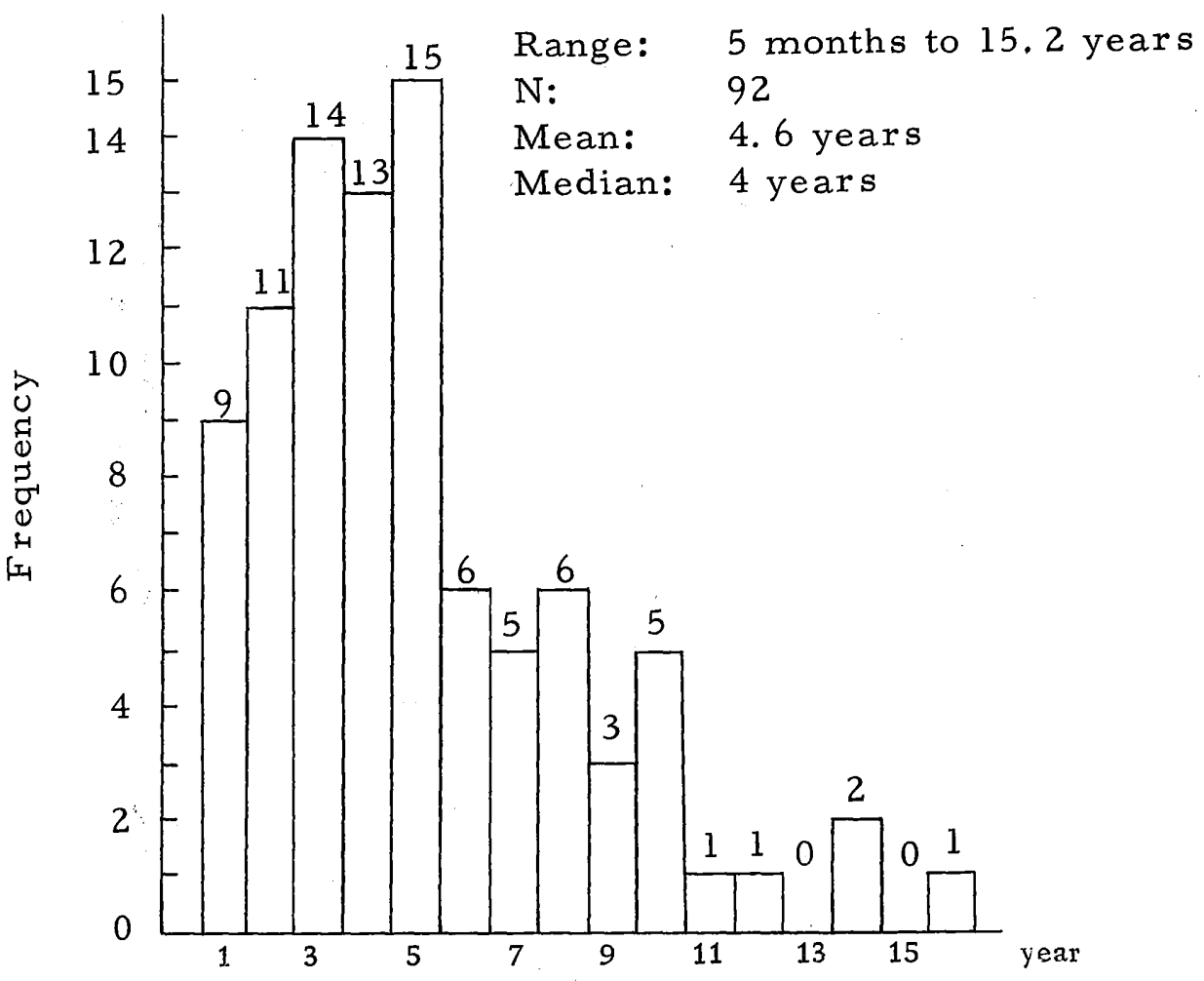

Figure 4. Time lapse from filing of divorce complaint to last court action. 


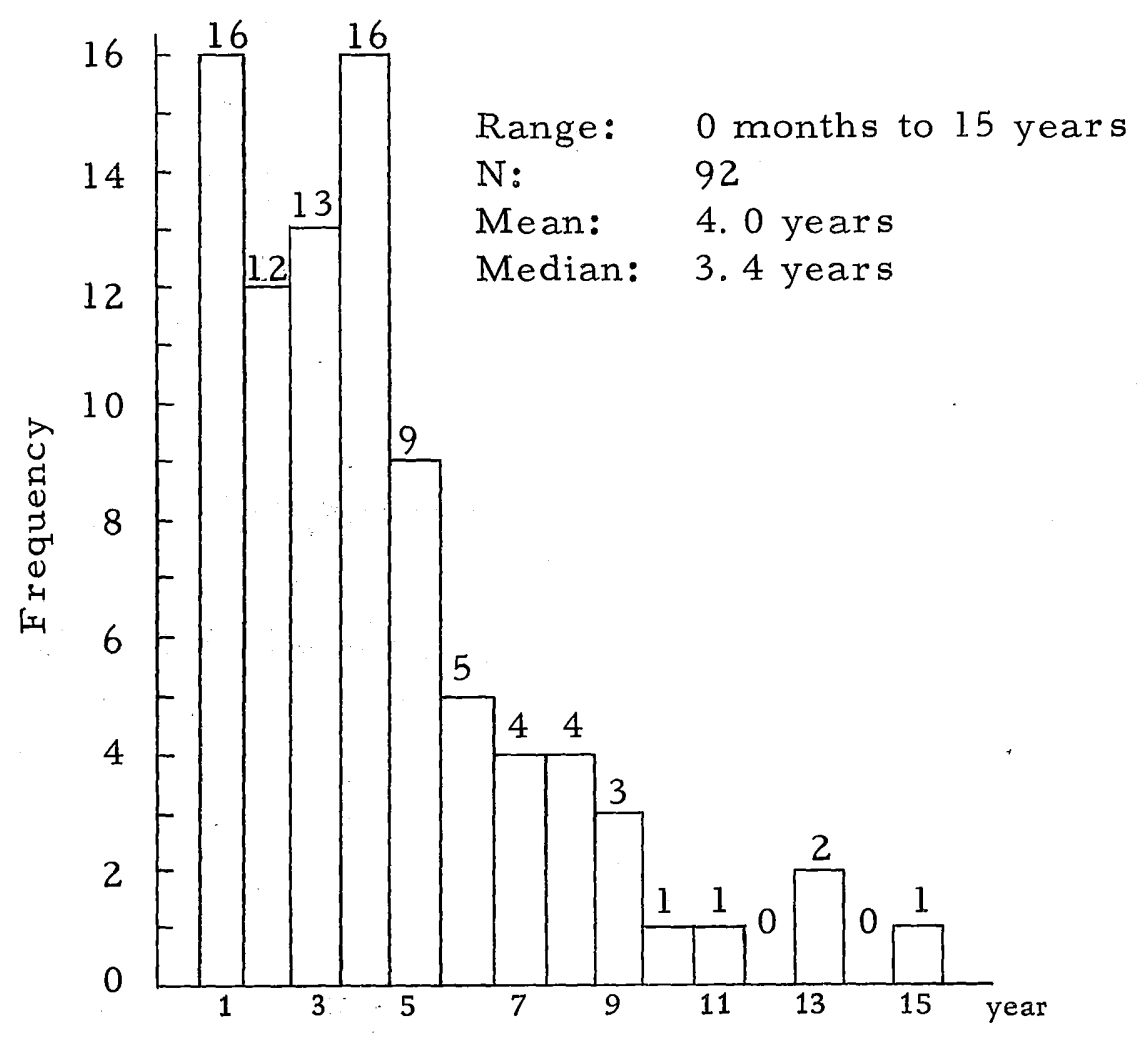

Figure 5. Time lapse between divorce decree and last court action.
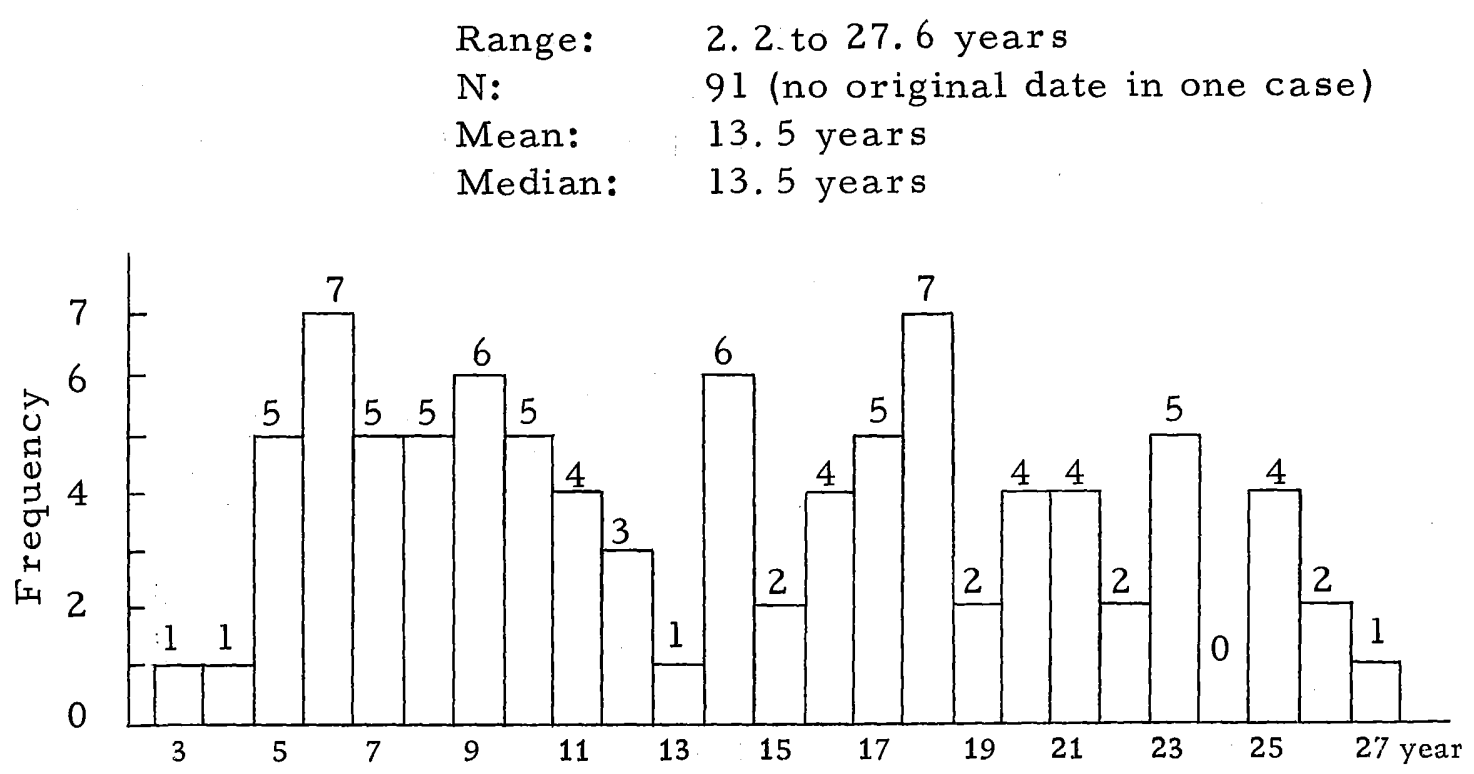

Figure 6. Year from date of marriage to last court action. 
strength to abide by such commitments . . . which call for significant sacrifices and compromises.

This is the time when children are born, financial pressures are frequently heavy, and if one or both partners lack the capacity for mature growth and problem-solving, the marriage may be terminated by divorce.

Figure 2 indicated that in 70 out of the 92 cases studied, divorce was completed within nine months after the initial filing. Speculation concerning this is that:

1. After a couple has filed for divorce the decision to follow through is generally made.

2. Divorce is a speedier process than public opinion usually considers it. Even though this is a sample of the more difficult cases, which would presumably take longer to process, in $77 \%$ the decree was granted within nine months of the filing date. Only 22 of these cases were carried beyond the nine-month period.

As noted in Figure 3, the length of marriage from the date of marriage to the divorce decree ranged from 13 months to 25.6 years with a mean length of 9.55 years and a median of 8.3 years. It is interesting to observe how the median of our sample compares to the median duration of marriage in the State of Oregon in 1965 of 5. 9 years, or 2. 4 years less than our sample (Bureau of Vital 
Statistics).

Figure 4 shows that in $67 \%$ of the cases studied the time lapse from the filing of the Divorce Complaint to last court action was five years or less. In $27 \%$ the time lapse was between five and ten years, and $6 \%$ of the cases studied continued the courtroom conflict for longer than ten years.

This does not mean that the latter cases were necessarily in constant court conflict during the entire period. For many people the court is seen as a resource for help in problem-solving; they tend to return to the court only when they cannot cope with problems alone.

The fact that $6 \%$ of the se cases continued courtroom conflict for periods longer than ten years may. be explained in the following ways:

1. The family may have continued in conflict throughout the entire ten-year period.

2. The family who sees the court as a problem-solving resource may be returning for help after a period of years during which there was no court action.

3. The parents may be responding to a child's manipulation, or to the changing needs of the child, in seeking a change of custody after a ten-year period.

Our feeling is that since human conditions are not static, a 
court decision which was carefully thought out and workable at an earlier period in the life of the child and parents is not necessarily the best decision for all time.

In Figures 4 and 5, the time lapse can be thought of as a typical cross section. The last court action is that court action recorded at the time of our study and the individual cases can and probably: will be returning for court action at some future date.

The one family that returned to court, after 15 years had elapsed following the divorce, was involved in considerable dispute over large sums of money and "change of custody" was only incidental.

Figure 5 points out the fact that a marriage relationship does not end with divorce, contrary to public opinion that when the divorce decree becomes final the marriage ties are automatically dissolved. It is shown here that in the sample studied the relationship continued long after the divorce. It is also shown that people returning to court have had wide ranges in length of time of relationship when both marriage and divorce are considered.

Another way of looking at the continuation of the relationship after the divorce is in terms of what Blanck and Blanck (1969) refer to as "the psychological process of terminating object relations." These authors feel that ".. the matter of severing ties to the partner is of far greater importance than is usually considered," 
and that a gradual tapering off of emotional attachment (largely on an unconscious level) is necessary before the divorced partners are able to reinvest psychic energy in the development of new interests and interpersonal relationships.

\section{THE GROUNDS FOR DIVORCE, THE BILL OF PARTICULARS, AND THE CHANGED CIRCUMSTANCES}

There must be legal grounds on which the divorce is being sought. As mentioned in Chapter III, the se general "grounds" are supplemented by the recital of particular offenses relative to the individual case. The Grounds for Divorce in the original complaint listed "cruel and inhuman treatment" in 89 cases, "desertion" in 2 cases, and "incarceration in a state penal institution" in 1 case.

Although the legal grounds on which 89 divorces were based came under the heading "cruel and inhuman treatment," there is a long list of particulars under this heading.

The fact that the law requlires that one party: be "innocent" and the other "guilty," makes for a stilted and stereotyped repetition of legal terms of abuse throughout the court records studied. The legal wording in the original complaint which is served to the defendant in a divorce case probably propels more people into court than any other single thing.

The Bill of Particulars in the original complaint was divided 
into 13 major categories of particulars in our reading guide. The various lettered particulars were reported 260 times with a range of 0 to 6 particulars per case, with a mean of 2.8 per case and a median of 3 per case. Figure 7 reveals the frequency of use for each category and the sex of the reporting party.

Large groupings of cases were found around the particulars of $E$ (physical abuse), $F$ (verbal abuse), and $M$ (other). It appeared that these particulars could be further specified for greater clarity and it was decided that Physical Abuse, Verbal Abuse and Other would be divided into sub-categories. Figures 8,9 , and 10 show the frequency: with which each of these sub-categories was used.

Most charges of physical and verbal abuse were made by the wives against their husbands. "Late hours" was charged against the husbands by the wives in 13 instances, while the husbands made the same charge in only 2 instances.

There were 32 Cross Complaints with the Grounds for Divorce listed as "cruel and inhuman treatment" in 30 cases, "desertion" in 1 case, and the "marriage not legal" in 1 case.

Of the 32 Cross Complaints, 27 reported a Bill of Particulars with the various particulars listed 94 times with a mean of 3.5 particulars per case and a median of 3 per case. Figure 11 shows the particulars listed in the Cross Complaint with the sex of the reporting party. 


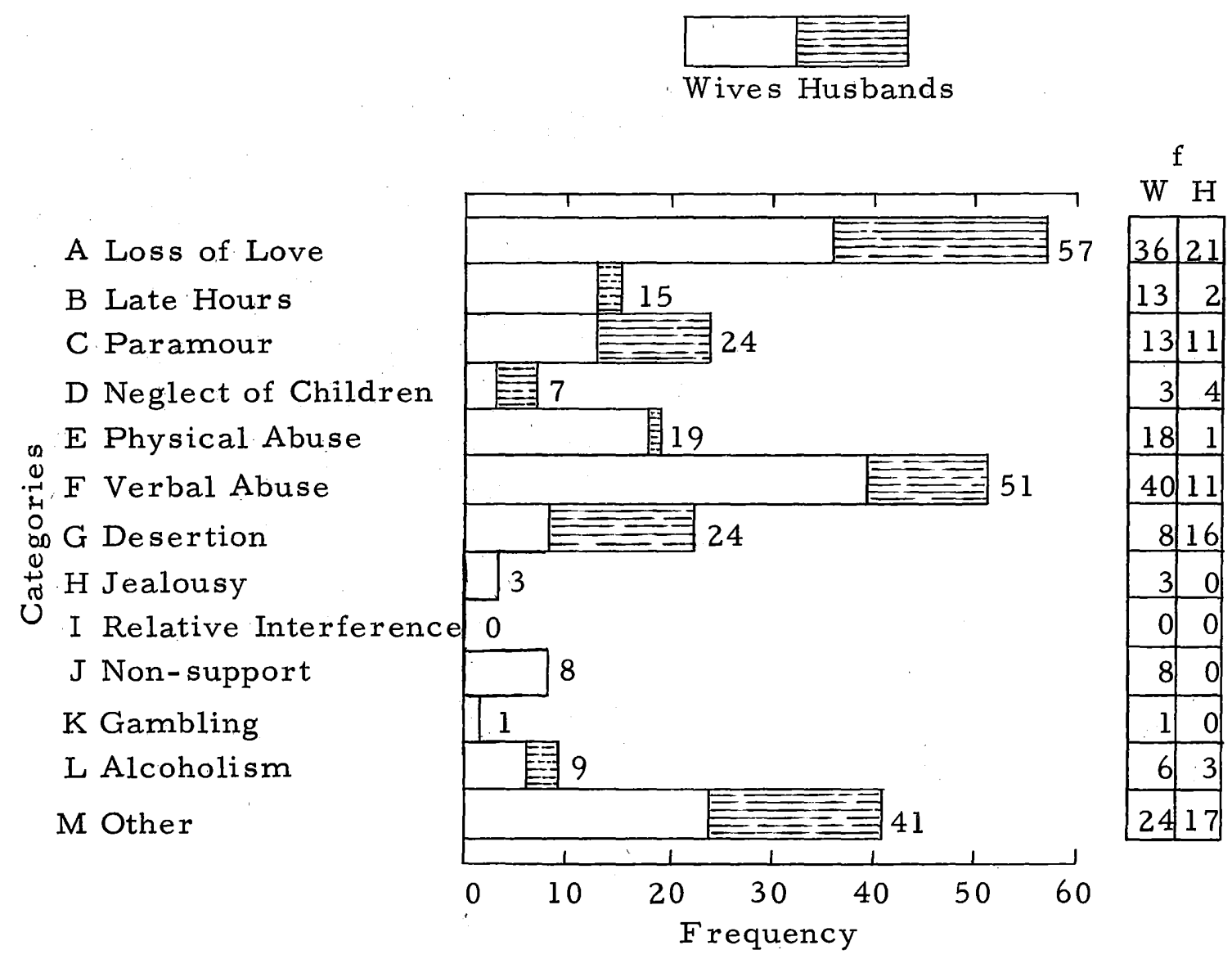

Figure 7. Particulars at time of complaint. Division by sex of reporting party. 
A s sault

Minor Physical Abuse

Attempts to Kill

Unspecified

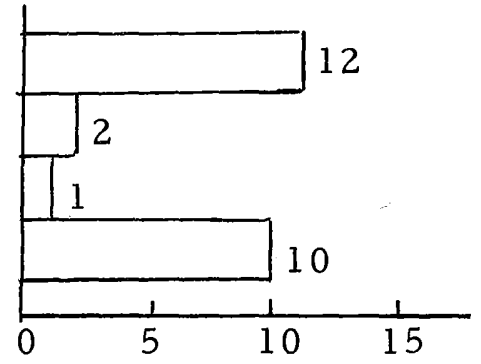

Figure 8. Sub-categories of particular $\dot{E}$, physical abuse.

Argumentative

False Accusations

Vile and Profane Language

Berating Remarks

Threats

Personal Indignities

Unspecified

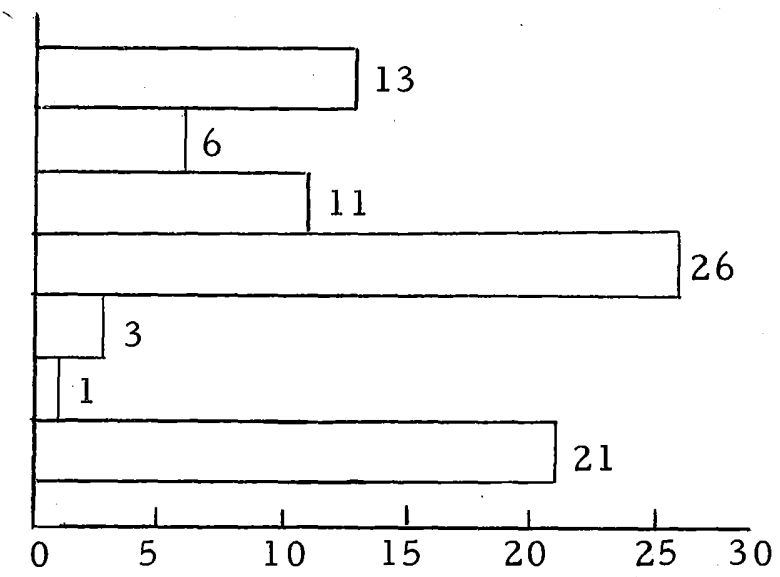

Figure 9. Sub-categories of particular F, verbal abuse.

Neglect of Marital Obligations

No Common Interests

Inconsiderate

Mental and Emotional Abuse

Financial Problems

Child's Emotional Needs Neglected

Drug Abuse

One Party being: Told to Leave the Home

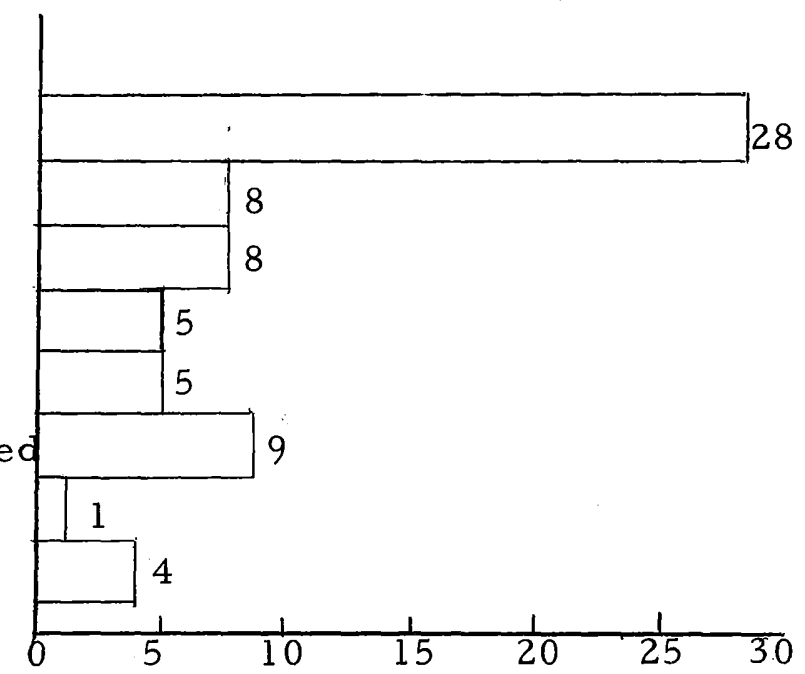

Figure 10. Sub-categories of particular M, other. 

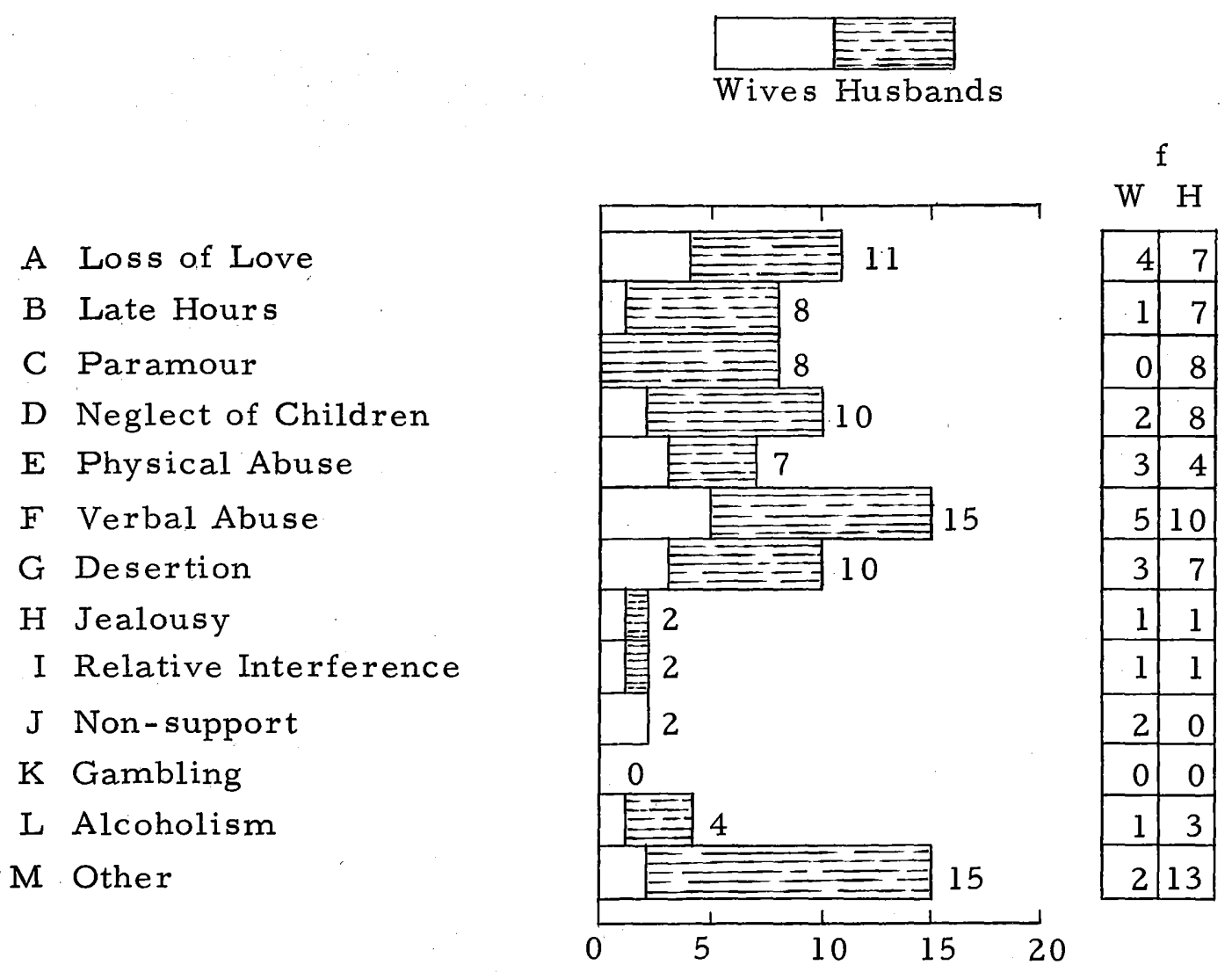

Figure 11. Particulars at time of cross complaint. Division by sex of reporting party. 
The charges in the Complaint and Cross Complaint by the plaintiffs and defendants do not appear to have much variation. It was observed that in the Cross Complaint no wives made the charge of "paramour" against their husbands, whereas 13 plaintiff-wives listed this in the complaint.

In our investigation of the Cross Complaint we again found large groupings of cases around the particulars of "Verbal Abuse" (F), and "Other" (M). "Physical Abuse" (E) was reported on three occasions as an assault, and in one case the form of physical abuse was not specified. The particulars of "Verbal Abuse" (F) and "Other" (M) were again divided into sub-categories as shown in Figures 12 and 13.

We found that when the divorced husband filed a Motion for Modification of the Divorce Decree, there were 15 charges of "immoral behavior" or "man in the home," 28 charges of "neglect and/or abuse of the children," 6 cases of the voluntary surrender of the children by the divorced wife, 6 cases where no reason was given, 1 case where a child requested a change of custody to her father, and 1 case in which the father stated he could provide a better home for the children than their mother was providing.

When the divorced wife filed the Motion to Modify the Divorce Decree, there were 7 charges of "neglect and/or abuse of the children, " 2 voluntary surrenders of custody by the father, 2 cases with 
Argumentative

False Accusations

Vile and Profane Language

Berating Remarks

Unspecified

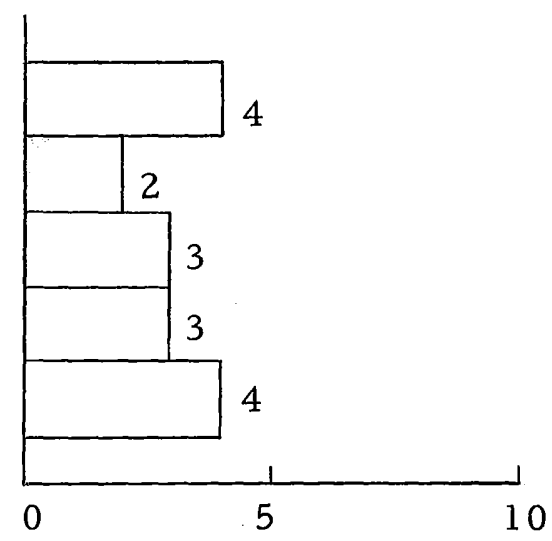

Figure 12. Sub-categories of particular F, verbal abuse.

Neglect of Marital Obligations

No Common Interests

Inconsiderate

Mental and Emotional Abuse

Financial Problems

Child's Emotional Needs Neglected

Drug Abuse

One Party being. Told to Leave the Home

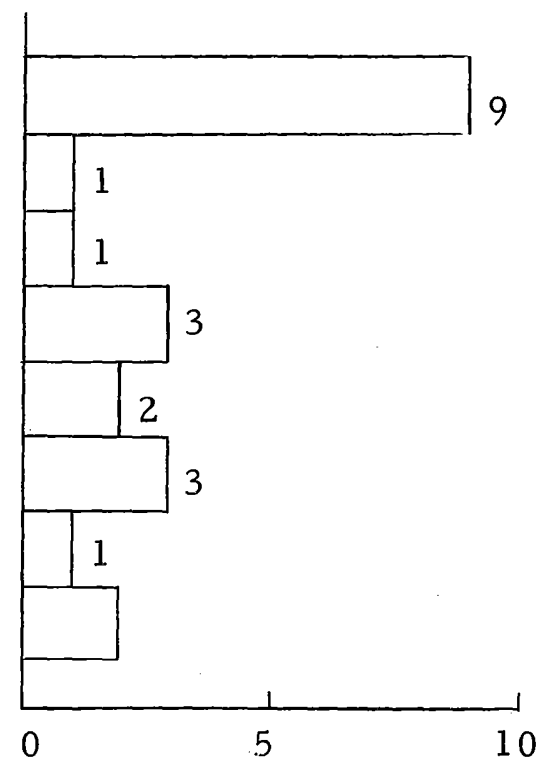

Figure 13. Sub-categories of particular $M$, other. 
no reason given, and 1 case of a mother who requested custody because her ex-husband would not comply: with the Divorce Decree in allowing her to visit the children.

Due to the inconsistencies in data gathering and court records, and since our study of subsequent motions did not add any new categories that were not found in the first Motion to Modify the Divorce Decree, we did not go beyond the first motion.

The particular stated most frequently: by husbands (second most frequently by wives) is "loss of love." This implies a feeling that love had existed at one time within the marriage, but had been 1ost. This may also imply a feeling on the part of the spouse that love is something to be sought outside the marriage or within a subsequent marriage, as an object, rather than as an outgrowth of a relationship based on mutual consideration and respect.

The idea of the "role oriented vs. the goal oriented" outlook as presented by Glasser (1970), seems applicable in relating to the various reasons for divorce given in the complaints studied. According to this premise, our current society is more concerned with role identity, with personal fulfillment and the need to feel loved and worthwhile, than it is concerned with survival or the attainment of goals. Thus, in marriage, people are seeking personal satisfaction more than they were in the days when marriage was based on practical aspects of survival, when spouses worked together toward 
common goals, with little leisure left to consider whether or not the marriage was fulfilling in a personal sense. In today's marriages, partners expect to identify ideologically as well as biologically.

\section{CHILDREN}

A descriptive analysis of the children of the parties involved in custody changes seems appropriate before actually considering custody changes. The 92 families in our sample had a total of 207 children with a range of zero to seven children per family. The children unborn at the time of filing for the divorce were counted as "0" for statistical purposes. This figure does not indicate the exact number of children, since 18-year-olds are not usually mentioned in the Divorce Decree. There was one instance where an 18-year-old was reported and in this case the person:was not listed in the frequency distribution for family size. It should also be noted that at times stepchildren are not recorded in the case record because they are not part of the "legal" family. There is, therefore, no way of accurately reporting exact totals of children per family. Table II, the frequency distribution of family size, does indicate that of the sample available the mean was 2.2 children per family, and a median of 2 children per family. 
TABLE II

FREQUENCY DISTRIBUTION OF FAMILY SIZE

\begin{tabular}{|c|c|c|c|c|c|c|c|c|}
\hline & & & Far & ily $\mathrm{Siz}$ & & & & \\
\hline & $0-1$ & 2 & 3 & 4 & 5 & 6 & 7 & Total \\
\hline Frequency & 31 & 28 & 19 & 10 & 3 & 0 & 1 & 92 \\
\hline Percentage & 33.7 & 30.4 & 20.6 & 10.9 & 3.3 & 0 & 1.1 & \\
\hline & $\begin{array}{l}\text { Ran } \\
\mathrm{N}: \\
\mathrm{Mea} \\
\mathrm{Mec}\end{array}$ & 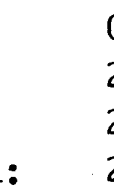 & $\begin{array}{l}\text { (unbor } \\
7 \\
2 \text { child }\end{array}$ & $\begin{array}{l}\text { to } 7 \\
\mathrm{en} / \mathrm{fa}\end{array}$ & & & & \\
\hline
\end{tabular}

The mean family size for all couples divorced in the State of Oregon in 1965 having one or more children was also 2.2 (Bureau of Vital Statistics).

TABLE III

FREQUENCY DISTRIBUTION: FAMILY SIZE OF ALL COUPLESDIVORCING IN OREGON IN 1965 (FAMILIES WITH NO CHILDREN EXCLUDED)

\begin{tabular}{cccccccccr}
\hline & \multicolumn{7}{c}{ Family Size } & & \\
& 1 & 2 & 3 & 4 & 5 & 6 & $7+$ & Total \\
\hline Frequency & 1264 & 1094 & 633 & 321 & 113 & 42 & 29 & 3496 \\
Percentage & 36.2 & 31.3 & 18.1 & 9.2 & 3.2 & 1.2 & .8 & \\
\hline
\end{tabular}

$\begin{array}{ll}\text { Mean: } & 2.2 \\ \text { Median: } & 2\end{array}$


We, therefore, developed a hypothesis that our sample was no different than the couples having one child or more, who were divorced in Oregon in 1965 in direct relationship to the size of the families of the two groups. A comparison of the two groups was made by means of Chi Square. The Chi Square of the sample was 2. 05. Chi Square at the .05 level with 6 degrees of freedom is 12.59. Therefore, the difference was not statistically significant and the hypothesis of there being no difference between the groups was accepted. The results of the Chi Square comparison are shown in Table IV.

\section{TABLE IV}

CHI SQUARE: COMPARISON OF SAMPLE FAMILY SIZE WITH THAT OF THE FAMILY SIZE OF ALL DIVORCED COUPLES IN OREGON IN 1965

\begin{tabular}{lrrrrrrrrr}
\hline & & \multicolumn{7}{c}{ Family Size } & An \\
& $0-1$ & 2 & 3 & 4 & 5 & 6 & 7 & Total \\
\hline \multirow{2}{*}{ Sample } & 31 & 28 & 19 & 10 & 3 & 0 & 1 & 92 \\
Oregon & 1264 & 1094 & 633 & 321 & 113 & 42 & 29 & 3496 \\
Total & 1295 & 1122 & 652 & 331 & 116 & 42 & 30 & 3588 \\
\hline & $x^{2}$ sample $=2.05$ & $\chi^{2} .05,6 \mathrm{df}=12.59$ & &
\end{tabular}

While our study encompassed only 92 families involving cus tody proceedings during the year 1965, the total number of divorcing 
families for the entire state of Oregon for the same year was 3, 496. The figure increases dramatically when the total number of members of extended families touched by divorce are added to this:

$$
\begin{array}{lc}
\text { Number of families touched by divorce: } & 3,495^{1} \\
\text { Number of children touched by divorce: } & 7,671^{1} \\
\text { Total members of nuclear family: } & 14,661 \\
\text { Nuclear family + grandparents: } & 28,641 \\
\text { Nuclear family + grandparents + stepparents: } & 35,629
\end{array}
$$

The point made here is that since divorce influences so many lives in our society in so direct a way, society must develop a more enlightened approach toward divorce and its concomitant problems. Of the total population of children in the sample, 101 were males, or $48.8 \%$, and 106 were females, or $51.2 \%$ of the total. The ages of the children ranged from unborn to age 17. Ages of five children were not recorded in the case records and one 18-year-old was not listed in our statistical computations, leaving an $N$ (total) of 201 children. Table V shows the distribution of the children's ages at the time of filing.

Since there was often more than one child per family, and the range of ages was great, the value of a mean was considered questionable and, therefore, was not computed.

${ }^{1}$ Figures taken from the Bureau of Vital Statistics (Portland, Oregon); other figures are projected. 
TABLE V

FREQUENCY DISTRIBUTION OF CHILDREN'S AGE AT TIME OF FILING DIVORCE COMPLAINT

\begin{tabular}{cc||cc}
\hline Age & $f$ & Age & $f$ \\
\hline 0 & 3 & & \\
1 & 26 & 9 & 12 \\
2 & 17 & 10 & 9 \\
3 & 14 & 11 & 10 \\
4 & 17 & 12 & 8 \\
5 & 12 & 13 & 8 \\
6 & 15 & 14 & 10 \\
7 & 15 & 15 & 2 \\
8 & 16 & 16 & 4 \\
Total & 17 & & 3 \\
\hline
\end{tabular}

Range: $\quad 0$ (less than 6 months) to 17 (one 18-yearold not included)

N: $\quad 201$

Mean: Not computed

The age of the youngest child at the time of filing ranged from unborn to 14 years with two children unborn at the time of filing.

The mean age of the youngest child in each divorcing family. was 4.2 years with a median of 3 years. Table VI shows the frequency distribution of the youngest child at the time of filing.

Table VI suggests various lengths of time in which families can remain engaged in adversary proceedings. Out of the sample studied, two families can stay engaged in adversary process for 21 years; twenty-seven families for 20 years; forty families (with children age 
TABLE VI

FREQUENCY DISTRIBUTION: AGE OF YOUNGEST CHILD

AT TIME OF FILING DIVORCE COMPLAINT

\begin{tabular}{cc|cc}
\hline Age & $\mathrm{f}$ & Age & $\mathrm{f}$ \\
\hline 0 & 2 & & \\
1 & 27 & 9 & 3 \\
2 & 11 & 10 & 2 \\
3 & 8 & 11 & 2 \\
4 & 8 & 12 & 1 \\
5 & 6 & 13 & 0 \\
6 & 9 & 14 & 2 \\
7 & 6 & 15 & 0 \\
8 & 2 & 16 & 0 \\
\end{tabular}

$\begin{array}{ll}\text { Range: } & 0 \text { (unborn) to } 14 \\ \mathrm{~N}: & 89(2 \text { cases without ages; one child } 18) \\ \text { Mean: } & 4.2 \text { years } \\ \text { Median: } & 3 \text { years }\end{array}$

two and below) for 19 years. The latter group constitutes a total of 43. $5 \%$ of the population studied.

\section{CUSTODY CHANGES}

Custody is here defined as legal custody and not necessarily physical custody. For example, in a few cases we found situations where a child was living with one parent while the other parent had legal custody, as defined by the court.

We found that there were 43 cases in which there was no change of custody, 24 cases of one change, 21 cases of two changes, 
3 cases of three changes, and 1 case of four changes of custody.

Figure 14 shows the location of the custody changes within the legal process and the frequency of each individual legal action within the process.

It is shown here that out of 41 court actions prior to the divorce decree, only 6 resulted in change of custody. This seems to imply that the court does not readily make change in custody before granting the divorce. The figure also shows that nearly half (43\%) of first Orders Modifying the Divorce Decree resulted in custody change. After the influx of first motions to modify, there is a sharp drop in subsequent requests for modification.

This action shown by the court concurs with our feeling that the period just before and during the granting of the divorce decree is a time of great stress and emotional unheaval for the people involved; therefore, a cooling-off period allows for calmer and more rational attitudes on the part of both parents. The parents would be likely to be more amenable to planning for "the best interests of the child" after the strong feelings involved during the divorce have subsided. This figure shows that only a negligible number of families come back into court after the third modification order. There are several possible explanations for this:

1. The people involved may have become more stabilized in their life patterns by this time. They may have developed 
Order Pendente Lite

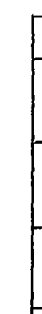

Modification of Pendente Lite

Divorce Decree

First Modification Order

Second Modification Order

Third Modification Order

Fourth Modification Order

Fifth Modification Order

Sixth Modification Order

Seventh Modification Order

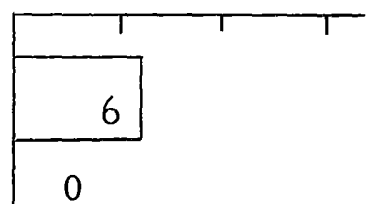

Total number of individual court actions

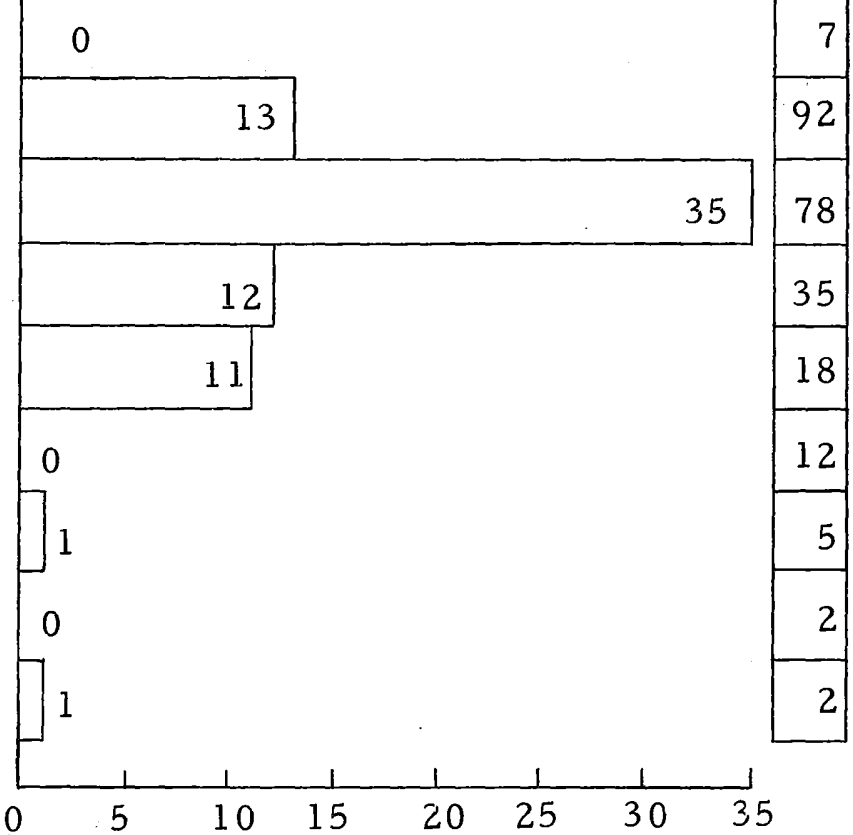

Figure 14. Location of custody changes within the legal process. 
new interests and relationships with other people.

2. They may desire more court litigation but be unable to afford attorney fees.

3. They may find it difficult to find an attorney who will handle their case.

4. The children involved in custody dispute may have attained their majority.

5. The ex-spouses may be separated by great geographical distances and be less inclined to engage in continued litigation.

We were interested in looking at the possibility of a direct relationship between the number of custody changes and the ages of the children at the time of filing. We had developed a hypothesis that children in their teen years were more liable to change custody than those of a younger age. We investigated the hypothesis by means of Chi Square. The computed Chi Square of our sample was 30.89. Chi Square at the .05 level with 20 degrees of freedom is 31.41 , indicating no significance. Our hypothesis was disproved and we found the age of the child to be insignificant in relation to custody changes. The results of the Chi Square computation are shown in Table VII.

There were 103 children that did not actually change custody, although custody. was at question in the legal suit. Sixty-eight 
TABLE VII

CHI SQUARE: RELATIONSHIP BETWEEN AGE OF CHILDREN AT 'TIME OF FILING AND NUMBER OF CUSTODY CHANGES

\begin{tabular}{lcccccc}
\hline $\begin{array}{l}\text { Age at } \\
\text { Filing }\end{array}$ & \multicolumn{5}{c}{ Number of Custody Changes } & Total \\
\cline { 2 - 6 } $0-2$ & 0 & 1 & 2 & 3 & 4 & 46 \\
$3-5$ & 25 & 15 & 3 & 0 & 0 & 43 \\
$6-8$ & 28 & 9 & 6 & 3 & 0 & 46 \\
$9-11$ & 15 & 8 & 7 & 1 & 0 & 31 \\
$12-14$ & 6 & 16 & 3 & 1 & 0 & 26 \\
$15-18$ & 7 & 2 & 0 & 0 & 0 & 9 \\
Total & 103 & 68 & 24 & 5 & 1 & 201 \\
\hline
\end{tabular}

$$
x^{2} \text { sample }=30.89 \quad x^{2} .05,20 \mathrm{df}=31.41
$$

children were involved in one change; 24 were involved in two changes; 5 were changed on three occasions; and 1 child was involved in four custody changes.

Tables VIII and IX show the sex and age of those children who had one and two custody changes and the parent who received custody. It should be noted that the children are listed strictly by the number of custody changes and they are listed at each instance in which there was a change in custody. Therefore, some children are 
TABLE VIII

FREQUENCY DISTRIBUTION: AGE OF CHILDREN AT

FIRST CUSTODY CHANGE AND PARENT TO

WHOM CUSTODY WAS GRANTED

\begin{tabular}{|c|c|c|c|c|c|c|c|c|}
\hline \multirow[b]{2}{*}{ Parent } & \multirow[b]{2}{*}{ Child } & \multicolumn{6}{|c|}{ Age of Child } & \multirow[b]{2}{*}{ Tota } \\
\hline & & $0-3$ & $4-6$ & $7-9$ & $10-12$ & $13-15$ & $\begin{array}{l}16 \text { and } \\
\text { above }\end{array}$ & \\
\hline \multirow{2}{*}{ Father } & f-Male & 5 & 5 & 6 & 7 & 13 & 5 & 41 \\
\hline & f-Female & 0 & 7 & 4 & 7 & 3 & 7 & 28 \\
\hline \multirow{2}{*}{ Mother } & f - Male & 4 & 1 & 2 & 2 & 0 & 1 & 10 \\
\hline & f - Female & 2 & 2 & 0 & 3 & 2 & 2 & 11 \\
\hline
\end{tabular}

Male to father: Mean 10.7 years; Median 11 years.

Female to father: Mean 11.3 years; Median 11 years.

Male to mother: Mean 6.9 years; Median 6.5 years.

Female to mother: Mean 9.7 years; Median 11 years.

counted more than once. It is interesting to note that in the first change in custody, there was a distinct mode of 13 boys in the $13-$ to 15-year-old interval, who changed from the custody of the mother to the father.

The figures shown in Table VIII suggest the fact that society as embodied in the Circuit Court Judges feel that mothers should have custody of infant girls, and that teen-age boys frequently belong with their fathers. This is in line with our knowledge of theory regarding the developmental needs of children and is largely supported by the literature reviewed in this study. The judges in the 
TABLE IX

FREQUENCY DISTRIBUTION: AGE OF CHILDREN AT

SECOND CUSTODY CHANGE AND PARENT TO

WHOM CUSTODY WAS GRANTED

\begin{tabular}{|c|c|c|c|c|c|c|c|c|}
\hline \multirow[b]{2}{*}{ Parent } & \multirow[b]{2}{*}{ Child } & \multicolumn{6}{|c|}{ Age of Child } & \multirow[b]{2}{*}{ Total } \\
\hline & & $0-3$ & $4-6$ & $7-9$ & $10-12$ & $13-15$ & $\begin{array}{l}16 \text { and } \\
\text { above }\end{array}$ & \\
\hline \multirow{2}{*}{ Father } & f-Male & 0 & 2 & 2 & 1 & 0 & 1 & 6 \\
\hline & $f-$ Female & 0 & 0 & 2 & 3 & 2 & 0 & 7 \\
\hline \multirow{2}{*}{ Mother } & f-Male & 0 & 2 & 0 & 1 & 4 & 1 & 8 \\
\hline & $\mathrm{f}-$ Female & 0 & 0 & 4 & 2 & 3 & 1 & 10 \\
\hline & \multicolumn{2}{|c|}{$\begin{array}{l}\text { Male to father: } \\
\text { Female to father: }\end{array}$} & \multicolumn{6}{|c|}{$\begin{array}{l}\text { Mean } 9.1 \text { years; Median } 8.5 \text { years. } \\
\text { Mean } 11.4 \text { years; Median } 12 \text { years. }\end{array}$} \\
\hline & \multicolumn{2}{|c|}{$\begin{array}{l}\text { Male to mother: } \\
\text { Female to mother: }\end{array}$} & $\begin{array}{l}\mathrm{Me} \\
\mathrm{Me}\end{array}$ & $\begin{array}{l}11.5 \\
11.7\end{array}$ & $\begin{array}{l}\text { rears; } 1 \\
\text { rears; } 1\end{array}$ & $\begin{array}{l}\text { Median } \\
\text { Median }\end{array}$ & $\begin{array}{l}13 \text { years } \\
12 \text { years }\end{array}$ & \\
\hline
\end{tabular}

Multnomah County Court of Domestic Relations also serve as Juvenile Court Judges where they see a great many cases involving delinquent boys whose mothers are unable to cope with the developmental needs of their adolescent sons; thus, the judges are made constantly aware of this problem, especially, as it occurs where the mother is the sole parent.

Table IX shows that at the time of the second change in custody, the number of changes by sex of parent and by sex of child are more in balance than they were in Table VIII. This may be due to the fact that the most heated part of the dispute has subsided; change in 
circumstances required by law to effect change in custody no longer must be as grossly significant as formerly and the focus is more likely to be on the real needs of the child. By the time of the second custody change, both parties have been through the court and their situations have been documented; they are by this time well acquainted with the court process.

The third change in custody involved six children. One girl, age 12, went from the custody of the mother to the father. Custody of the five remaining children went to the mother from the fathers and these children included two boys, ages 12 and 19, and three girls, ages 10,12 and 17. A fourth change in custody involved a girl, age 12, who returned to the custody of her mother. It is interesting that this child changed custody from the mother to the father, back to the mother, returned to her father, and finally returned to her mother. Thus, there were four changes of custody resulting in the child returning to her starting point in the custody of the mother. We suspected that there was a relationship between the length of marriage and the number of changes in custody. Simple observation of our data seemed to indicate that the shorter the marriage, the more difficulty in settling the matter of custody. We, therefore, developed the hypothesis that there was an inverse relationship between the length of marriage (time lapse from date of marriage to date of filing) and the number of custody changes. Comparison was 
made by means of Chi Square. The computed Chi Square of our sample was 9.62. Chi Square at the 05 level with 12 degrees of freedom is 21.03 , indicating no significance to the relationship. Our hypothesis was disproved and therefore the length of marriage is not a significant variable in relationship to the number of custody changes. Table $\mathrm{X}$ presents these results.

TABLE X

CHI SQUARE: RELATIONSHIP BETWEEN LENGTH OF MARRIAGE TO FILING OF DIVORCE COMPLAINT AND NUMBER OF CUSTODY CHANGES

\begin{tabular}{cccccccc}
\hline $\begin{array}{c}\text { Length of } \\
\text { Marriage } \\
\text { (months) }\end{array}$ & 0 & 1 & 2 & 3 & 4 & Total \\
\cline { 2 - 7 } $0-43$ & $Q_{1}$ & 12 & 7 & 3 & 0 & 1 & 23 \\
$44-97$ & $Q_{2}$ & 10 & 7 & 4 & 2 & 0 & 23 \\
$98-171$ & $Q_{3}$ & 10 & 6 & 7 & 0 & 0 & 23 \\
$172-290$ & $Q_{4}$ & 10 & 4 & 7 & 1 & 0 & 22 \\
Total & 42 & 24 & 21 & 3 & 1 & 91 \\
\hline
\end{tabular}

$$
x^{2} \text { sample }=9.62 \quad x^{2} .05,12 \mathrm{df}=21.03
$$

Note: One case with no original date of marriage.

It should be noted in Table $X$ that there are 23 cases in each of the first three quartiles and 22 cases in the fourth quartile, for a total of 91 cases. One case from our original sample of 92 cases 
had to be eliminated in our computations involving the length of marriage (from the date of marriage) because the date of the marriage was missing from this case record.

At the time of filing the assumption was made, unless otherwise noted, that the party requesting custody had the physical custody of the children. Table XI shows the distribution of custody throughout the legal process.

TABLE XI

DISTRIBUTION OF CUSTODY THROUGH THE LEGAL PROCESS

\begin{tabular}{lccccc}
\hline & Filing & $\begin{array}{c}\text { Pendente } \\
\text { Lite }\end{array}$ & Divorce & $\begin{array}{c}\text { First } \\
\text { Order }\end{array}$ & $\begin{array}{r}\text { Final } \\
\text { Order }\end{array}$ \\
\hline Wife & 69 & 70 & 72 & 53 & 53 \\
Husband & 18 & 16 & 14 & 31 & 30 \\
Split & 3 & 2 & 4 & 8 & 8 \\
Court & 1 & 1 & 1 & 0 & 1 \\
Other & 1 & 3 & 1 & 0 & 0 \\
\hline
\end{tabular}

Table XI partially substantiates findings in the literature, i. e., mothers generally obtain custody of children at the time of the divorce. However, these figures also show the number of fathers getting custody at the time of the first order modifying the decree more than doubled over those who had it at the time of the divorce.

There is more split custody shown here ( 8 out of the total 92 in the final order) than the review of literature led us to expect. This 
may: be explained by the fact that children choose sides to some extent when the nuclear family is divided. This is another instance where the court must individualize and make specific plans to fit each family. situation.

Another factor to be considered is that as children reach adolescence they tend to identify more strongly: with the parent of the same sex. In a family where there are children of each sex there is more likely to be split custody, if the court adheres to this natural identification process.

In examining the sex of the plaintiff in relationship to custody, we found that of the 34 plaintiff husbands, 15 did not request custody at the time of filing, although after the filing this same group was involved in requesting custody. We also found one case of a plaintiffwife who indicated at the time of filing that it was her wish that her husband be granted custody. A further breakdown of the distribution of custody to the husbands through the legal process is available in Table XII.

The number of husbands who had custody more than doubled from the time of the Divorce Decree to the first Order Modifying the Divorce Decree.

It can be seen here that $26.5 \%$ of the plaintiff husbands have custody at the time of the divorce decree, while $8.6 \%$ of the defendant husbands have custody. This would indicate that Metz's (1968) 
TABLE XII

DISTRIBUTION OF CUSTODY TO HUSBANDS

DIVIDED BY PLAINTIFF/DEFENDANT

\begin{tabular}{lcccc}
\hline & Custody & Divorce & $\begin{array}{c}\text { First } \\
\text { Order }\end{array}$ & $\begin{array}{c}\text { Final } \\
\text { Order }\end{array}$ \\
\hline Plaintiff & All & 9 & 14 & 14 \\
Husband & Split & 2 & 3 & 3 \\
Defendant & All & 5 & 17 & 16 \\
Husband & Split & 2 & 5 & 5 \\
\hline
\end{tabular}

assertion that courts tend to award custody to the plaintiff is essentially correct. The trend still holds true at the time of the final order:

41. $2 \%$ plaintiff husbands had custody.

$27.6 \%$ defendant husbands had custody.

We believe there is an original distortion which skews the figures and tends to support Metz's position when in fact this position may not be accurate. There is societal sanction given for women to file for and obtain the divorce. Instances where the husband is the plaintiff may well be those situations where the wife does not want the children or where her conduct has been such that the husband's legal position is stronger. Therefore, even though statistics tend to support Metz's position we suspect his statement concerning husbands as plaintiffs is not completely defensible. 
In considering the above observations we felt that there seemed to be a relationship between the sex of the plaintiff and the number of custody changes. We drew the hypothesis that plaintiff-husbands stood a better chance of ultimately obtaining custody than did the plaintiff-wives. Chi Square was computed in order to examine this hypothesis. The computed Chi Square of our sample was 2.07. Chi Square at the .05 level with 4 degrees of freedom is 9.49 , indicating no significant difference between the plaintiff-husbands and plaintiffwives. Thus, the sex of the plaintiff is not significant in relation to who receives custody, or the number of custody changes. (Table XIII)

TABLE XIII

CHI SQUARE: RELATIONSHIP BETWEEN SEX OF PLAINTIFF AND NUMBER OF CUSTODY CHANGES

\begin{tabular}{lllllll}
\hline & \multicolumn{5}{c}{ Custody Changes } & \\
\cline { 2 - 6 } & 0 & 1 & 2 & 3 & 4 & Total \\
\hline $\begin{array}{l}\text { Husbands } \\
\text { Wives }\end{array}$ & 14 & 10 & 8 & 2 & 0 & 34 \\
Total & 29 & 14 & 13 & 1 & 1 & 58 \\
& 43 & 24 & 21 & 3 & 1 & 92 \\
\hline & $x^{2}$ sample $=2.07$ & $\chi^{2} \cdot 05,4 \mathrm{df}=9.49$ &
\end{tabular}

Despite the fact that custody for husbands more than doubled from the time of the Divorce Decree to the first Order Modifying 
the Divorce Decree, the proportion of custody changes was not significantly different for plaintiff-husband or plaintiff-wives.

A final hypothesis was developed and tested, which considered the size of families in relationship to the number of custody changes. Our hypothesis was that the greater the number of children in a family, the more the number of custody changes. Chi Square was again used in testing the relationship. The computed Chi Square of our sample was 13.19. Chi Square at the .05 level with 16 degrees of freedom is 26.30 , indicating no significant differences between the size of families and the number of custody changes. Thus, there is no significance in our sample to indicate that larger families have more custody changes. Table XIV shows the results of the Chi Square computation.

TABLE XIV

CHI SQUARE: RELATIONSHIP BETWEEN FAMILY SIZE AND CUSTODY CHANGES

\begin{tabular}{crrrrrr}
\hline \multirow{2}{*}{$\begin{array}{c}\text { Custody } \\
\text { Changes }\end{array}$} & $0-1$ & 2 & 3 & 4 & $5-7$ & Total \\
\cline { 2 - 7 } & $0-1$ & 12 & 11 & 6 & 1 & 43 \\
0 & 13 & 10 & 3 & 1 & 1 & 24 \\
1 & 9 & 6 & 3 & 3 & 2 & 21 \\
2 & 7 & 0 & 2 & 0 & 0 & 3 \\
3 & 1 & 0 & 0 & 0 & 0 & 1 \\
4 & 1 & 28 & 19 & 10 & 4 & 92 \\
Total & 31 & & & & & \\
\hline
\end{tabular}

$x^{2}$ sample $=13.19 \quad \chi^{2} .05,16 \mathrm{df}=26.30$ 
In reviewing this table, suggested reasons why our hypothesis that the greater the number of children in a family, the more the number of custody changes, was proved incorrect, are as follows: In large families affected by divorce, frequently there is not enough money for continued court litigation. Also, in the larger families, it would be more difficult to shift children from one household to another from the standpoint of space, as well as the additional stress involved in moving several children from one home to another.

\section{ACTIONS}

For our purposes each Roman numeraled section heading in the reading guide and all subsequent motions and orders for modification of the Divorce Decree, after the first Order, are defined as "court actions."

Because of the legal requirement that a complaint be filed for divorce, our sample of 92 cases contained a complaint in each case. This is also true regarding the Divorce Decree. However, there is not the same degree of consistency: in the filing of other legal documents within the record. In some instances of court action we expected a hearing and/or motion prior to the court action, but there is in these instances no record in the legal file of a motion or hearing. Figure 15 shows the legal process and the frequency of each 
Complaint

Answer

Cross Complaint

Show Cause for PL*

Answer to Motion PL

Order PL

Motion to Modify PL

Order Modifying PL

Divorce Decree

First Motion to Modify

First Order to Modify

Second Motion

Second Order

Third Motion

Third Order

Fourth Motion

Fourth Order

Fifth Motion

Fifth Order

Sixth Motion

Sixth Order

Seventh Motion

Seventh Order

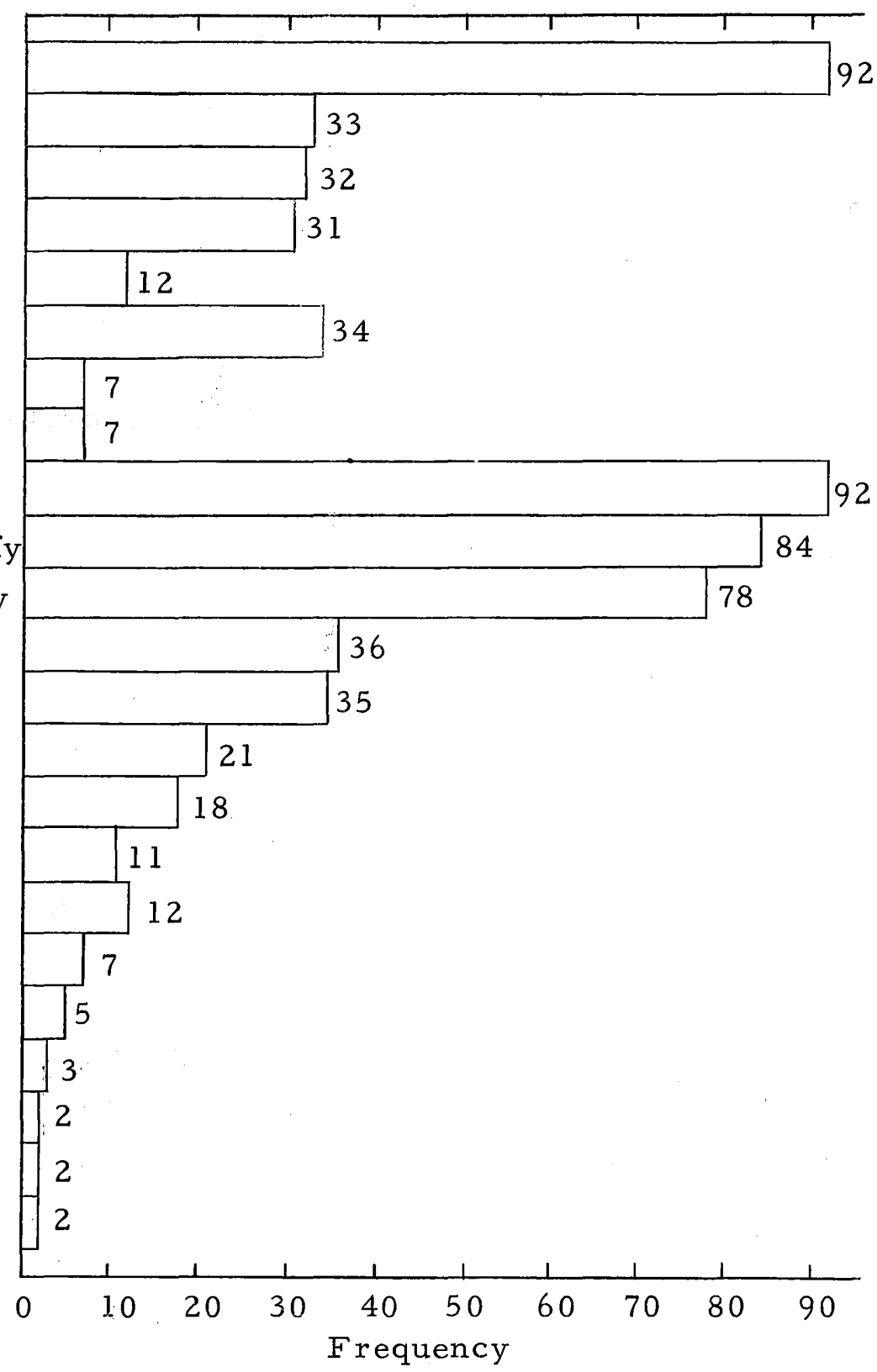

$* \mathrm{PL}=$ Pendente Lite

Figure 15. The legal process and the frequency of each court action. 
court action.

The number of legal actions involved in the individual cases of our sample ranged from 3 to 19 with a mean of 7.1 actions and a median of 6 actions per case.

Although the difference is not great, Figure 15 shows that there is a trend after the divorce decree for more motions than orders. This may indicate that some people may have learned ways to resolve their problems over time without the intervention of the court; although the motions are filed by attorneys, some parents may have learned to negotiate or to bring about changes in such a way that they do not have to return to court.

In our study of the legal process a number of hypotheses were developed in regard to a relationship of the number of court actions with such variables as family size, length of marriage, custody changes, and the number of court actions before the issuance of the Divorce Decree with the number of court actions after the Divorce Decree was issued.

Our first hypothesis was that the larger the family, the more the number of court actions. The development of this hypothesis was somewhat a result of our consideration of family size and the number of custody changes, since both hypotheses were developed at the same time. A comparison was made by means of Chi Square between one- and two-child families and those with three children or 
more to determine whether there was a relationship between family size and the number of court actions. The computed Chi Square of our sample was 2.20. Chi Square at the .05.level with 7 degrees of freedom is 14.07 , indicating no significant difference between the two groups. Thus, the family size is not a significant factor in the number of court actions. Table XV shows these results.

TABLE XV

CHI SQUARE: RELATIONSHIP BETWEEN FAMILY SIZE AND THE NUMBER OF COURT ACTIONS

\begin{tabular}{lccccccccc}
\hline $\begin{array}{l}\text { Family } \\
\text { Size }\end{array}$ & $3-4$ & $5-6$ & $7-8$ & $9-10$ & $11-12$ & $13-14$ & $17-18$ & $19-20$ & Total \\
\hline & 15 & 16 & 11 & 9 & 4 & 2 & 1 & 1 & 59 \\
$3-2$ & 9 & 11 & 4 & 4 & 2 & 2 & 1 & 0 & 33 \\
Total & 24 & 27 & 15 & 13 & 6 & 4 & 2 & 1 & 92 \\
\hline
\end{tabular}

Note: There were no cases in the 15-16 action interval.

$$
\chi^{2} \text { sample }=2.20 \quad \chi^{2} .05,7 \mathrm{df}=14.07
$$

The second hypothesis, tested, simply stated, was that the longer the couple was married, the better the chances of fewer appearances before the court and thus, the fewer the number of court actions. We considered the length of marriage from the date of the marriage to the filing for the divorce and related this time lapse to the number of court actions. Chi Square was again computed. The 
computed Chi Square of our sample was 14.14. Chi Square at the .05 level with 12 degrees of freedom is 21.03. Again, no significance was found in the relationship. Therefore, the length of marriage has.little effect on the number of court actions. Table XVI shows the resilts of the Chi Square computation.

TABLE XVI

CHI SQUARE: RELATIONSHIP BETWEEN LENGTH OF MARRIAGE TO FILING OF DIVORCE COMPLAINT AND NUMBER OF ACTIONS

\begin{tabular}{rlcccccc}
$\begin{array}{c}\text { Length of } \\
\text { Marriage } \\
\text { (months) }\end{array}$ & \multicolumn{7}{c}{ Actions } \\
\cline { 2 - 6 } $0-43$ & $Q_{1}$ & 5 & 5 & 5 & 6 & 2 & 23 \\
$44-97$ & $Q_{2}$ & 9 & 5 & 4 & 1 & 4 & 23 \\
$98-171$ & $Q_{3}$ & 3 & 10 & 4 & 4 & 2 & 23 \\
$172-290$ & $Q_{4}$ & 7 & 6 & 2 & 2 & 5 & 22 \\
Total & 24 & 26 & 15 & 13 & 13 & 91 \\
\hline
\end{tabular}

Note: One case not used because of no original marriage date.

$$
x^{2} \text { sample }=14.14 \quad x^{2} .05,12 \mathrm{df}=21.03
$$

The last hypothesis tested the relationship between the number of court actions and the number of custody changes. Our hypothesis was that the more the court actions, the more the custody changes. The computed Chi Square of our sample was 19.31. Chi Square at 
the .05 , level with 16 degrees of freedom is 26.30 , which disproved our hypothesis (Table XVII).

TABLE XVII

CHI SQUARE: RELATIONSHIP BETWEEN THE NUMBER OF COURT ACTIONS AND CUSTODY CHANGES

\begin{tabular}{crrcccc}
\hline $\begin{array}{c}\text { Custody } \\
\text { Changes }\end{array}$ & $3-4$ & $5-6$ & $7-8$ & $9-10$ & $11-19$ & Total \\
\cline { 2 - 6 } & 11 & 13 & 6 & 6 & 7 & 43 \\
0 & 10 & 7 & 4 & 1 & 2 & 24 \\
1 & 3 & 6 & 5 & 4 & 3 & 21 \\
2 & 0 & 1 & 0 & 1 & 1 & 3 \\
3 & 0 & 0 & 0 & 1 & 0 & 1 \\
4 & 24 & 27 & 15 & 13 & 13 & 92 \\
\hline
\end{tabular}

$$
x^{2} \text { sample }=19.31, x^{2} .05,16 \mathrm{df}=26.30
$$

Here again it is clearly seen that the court seeks to remain objective and to decide each case on its individual merits. The table shows that there is no correlation between the number of court actions and the number of actual custody changes. The court is not influenced by the increase in number of actions but makes it decisions in a calm and rational manner based on the continued best interests of the child.

It became apparent in our study of the legal process that a number of the marital parties in our sample spent more time 
involved in the legal proceedings than they had in actual months married. It was decided to look at this group and investigate any relationships between this group and other aspects of our study.

This group consisted of 29 cases, Tables XVIII through XXI provide a graphic representation of the time elapsed from the date of marriage to the various legal actions and the time elapsed from one court action to another.

TABLE XVIII

FREQUENCY DISTRIBUTION: LENGTH OF MARRIAGE TO FILING OF DIVORCE COMPLAINT

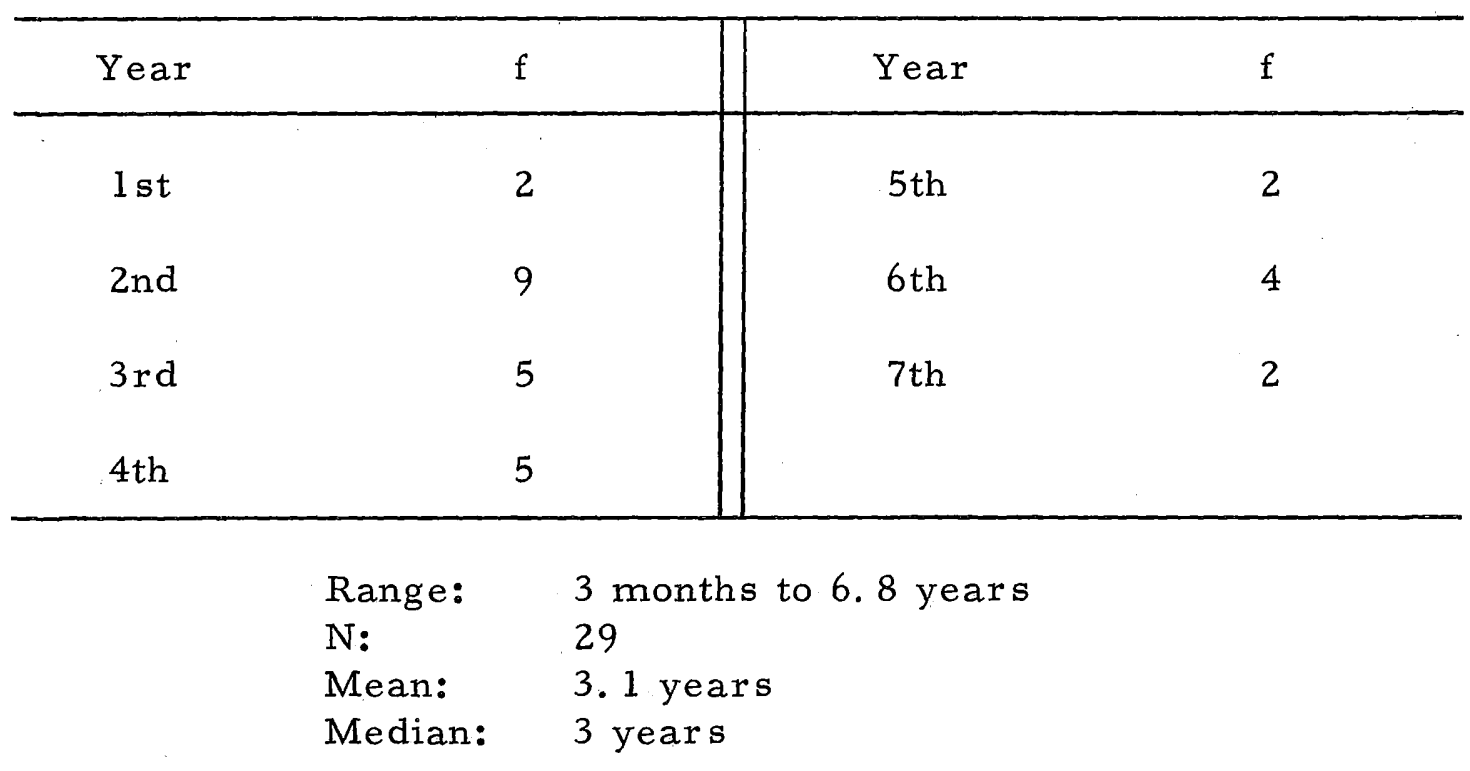


TABLE XIX

FREQUENCY DISTRIBUTION: LENGTH OF LEGAL PROCESS

\begin{tabular}{ll|ll}
\hline Year & $\mathrm{f}$ & Year & $\mathrm{f}$ \\
\hline 1st & 0 & 9 th & 2 \\
2nd & 1 & 10 th & 5 \\
3rd & 4 & 11 th & 1 \\
4th & 3 & 12 th & 0 \\
5th & 5 & 13 th & 0 \\
6th & 1 & 14 th & 2 \\
7th & 2 & 15 th & 0 \\
8th & 2 & 16 th & 1 \\
\hline
\end{tabular}

Range: $\quad 2$ years to 15.2 years

N: $\quad 29$

Mean: $\quad 6.3$ years

Median: $\quad 6.2$ years

TABLE XX

FREQUENCY DISTRIBUTION: DIFFERENCE BETWEEN

TIME SPENT IN COURT AND THAT SPENT IN

MARRIAGE (INTERVALS BY MONTHS)

\begin{tabular}{rl||cc}
\hline Months & $f$ & Months & $f$ \\
\hline $0-12$ & 7 & $61-72$ & 1 \\
$13-24$ & 4 & $73-84$ & 2 \\
$25-36$ & 5 & $85-96$ & 2 \\
$37-48$ & 2 & $97-108$ & 1 \\
$49-60$ & 3 & $109-120$ & 2 \\
\hline
\end{tabular}

Range: $\quad 2$ months to 9.5 years

N: $\quad 29$

Mean: $\quad 3.6$ years

Median: 2.5 years 
TABLE XXI

\section{FREQUENCY DISTRIBUTION: RATIO OF LENGTH \\ OF TIME IN LEGAL PROCESS TO \\ LENGTH OF MARRIAGE}

\begin{tabular}{cc|cc}
\hline Ratio & $\mathrm{f}$ & Ratio & $\mathrm{f}$ \\
\hline $1.0-1.9$ & 13 & $6.0-6.9$ & 0 \\
$2.0-2.9$ & 10 & $7.0-7.9$ & 0 \\
$3.0-3.9$ & 2 & $8.0-8.9$ & 2 \\
$4.0-4.9$ & 0 & $9.0-9.9$ & 0 \\
$5.0-5.9$ & 1 & $10.0-10.9$ & 1 \\
\hline
\end{tabular}

$\begin{array}{ll}\text { Range: } & 1.1 \text { to } 10.1 \text { times more } \\ \text { N: } & 29 \\ \text { Mean: } & 2.8 \text { times } \\ \text { Median: } & 2.0 \text { times }\end{array}$

A possible explanation here is that if a couple has not stayed together long enough to develop successful patterns for dealing with disagreements that arise within the marriage, they may be unable to cope with the problems that remain after the marriage is terminated. Dominian (1968) refers to couples whose marriages break down during this early period as people who lack the qualities necessary to establish a minimum physical and emotional relationship.

It should be noted that in the one case in which the couple spent 10. 1 times the length in the court proceedings than they did in marriage, they were married for 10 months prior to filing and spent 13. 6 years from filing to the last court action.

In our study of this group of 29 cases, we developed a 
hypothesis that when the husband filed for divorce the time spent in the legal process was greater than the actual time married. Observation of our raw data seemed to indicate this to be the case. Chi Square was computed to test our hypothesis. The computed Chi Square of our sample was 2.35. Chi Square at the . 05 level with 1 degree of freedom is 3.84, which disproved our hypothesis. Chi Square showed that there was no significant relationship between the husband, as plaintiff, and the time spent in the legal process (Table XXII).

TABLE XXII

CHI SQUARE: RELATIONSHIP BETWEEN SEX OF PLAINTIFF AND WHETHER OR NOT THE MARRIAGE LASTED LONGER THAN THE LEGAL PROCESS

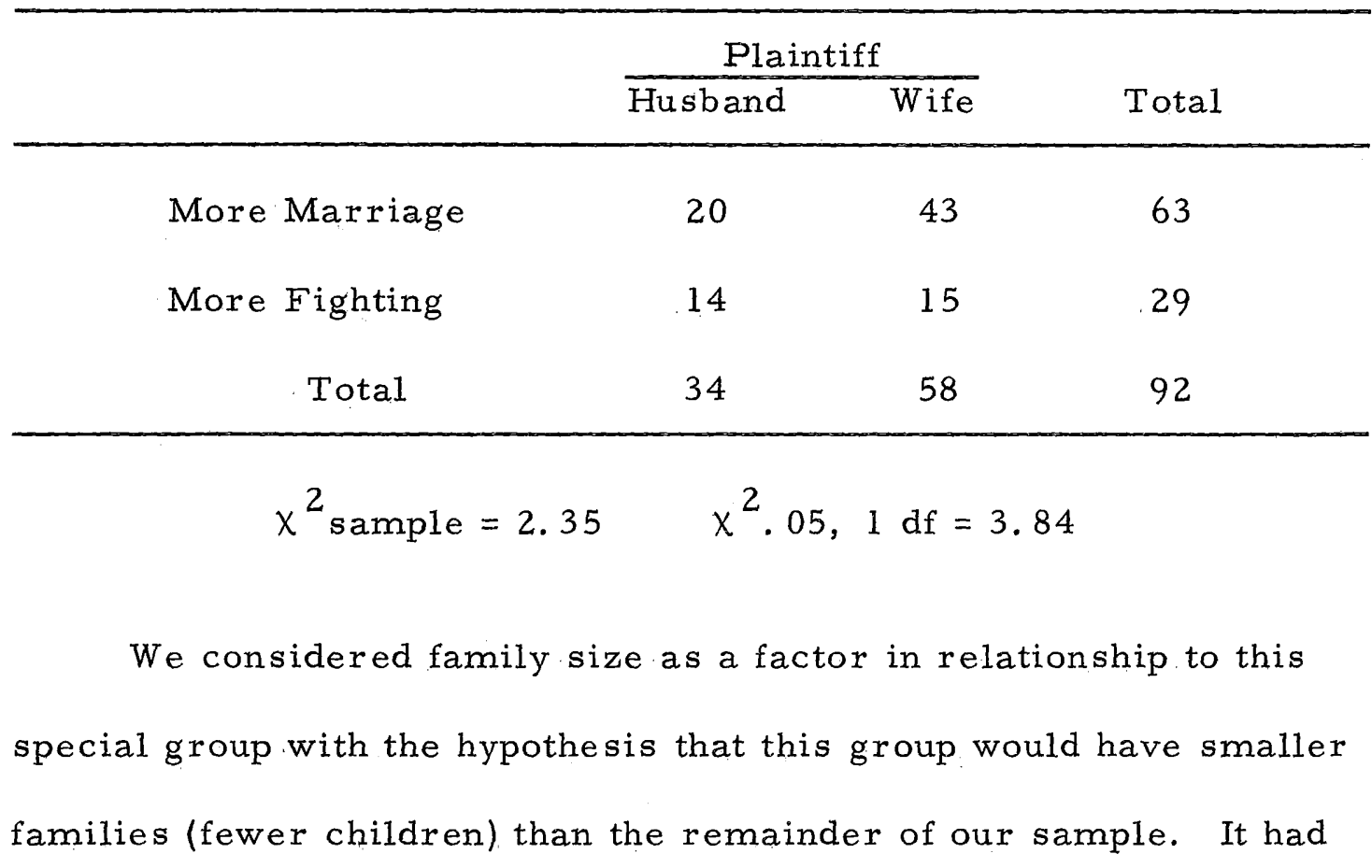


been observed that the mean length of marriage for this group was less than the mean length for our total sample. It seemed logical to conclude that with a shorter length of marriage, the family size would be smaller. We tested our hypothesis by means of Chi Square. The computed Chi Square of our sample was 20.27. Chi Square at the . 05 level with 4 degrees of freedom is 9.49 , indicating that our findings.were significant and our hypothesis was therefore accepted. Table XXIII shows the results of the computation of Chi Square.

TABLE XXIII

CHI SQUARE: RELATIONSHIP BETWEEN FAMILY SIZE AND WHETHER OR NOT THE MARRIAGE LASTED LONGER THAN THE LEGAL PROCESS

\begin{tabular}{|c|c|c|c|c|c|c|}
\hline & \multicolumn{5}{|c|}{ Number of Children } & \multirow[b]{2}{*}{ Total } \\
\hline & $0-1$ & 2 & 3 & 4 & $5-7$ & \\
\hline More Marriage & 12 & 22 & 16 & 9 & 4 & 63 \\
\hline More Fighting & 19 & 6 & 3 & 1 & 0 & 29 \\
\hline Total & 31 & 28 & 19 & 10 & 4 & 92 \\
\hline
\end{tabular}

The above analysis was, perhaps, our most significant finding. Smaller-sized families were very much in evidence in this group. The major difference between this group and the remainder of our sample was in the one-child families. In the cases in which the 
lengths of marriage were longer than the time spent in the legal process, there were 12 one-child families, where the expected number was 21.2. In the cases in which the length of time spent in the legal process was greater than the length of marriage there were 19 onechild families, where the expected number was 9.8. Other areas of significance were found in the group experiencing greater lengths in time spent in the legal process than in marriage. These were found in families of more than three children in which the observed frequency: was four children and the expected frequency was 10. 5 .

We concluded our study of those cases in which the time spent in legal process was longer than the length of marriage by the development of two hypotheses which compared this group to the remainder of our sample in relationship to the number of custody changes and the number of court actions.

In considering the aspect of custody changes, our hypothesis was that the group of 29 cases would have more custody changes than the remainder of our sample. The computed Chi Square of our sample was 8.62. Chi Square at the .05 level with 4 degrees of freedom is 9.49. Chi Square did not support our hypothesis and consequently there was no significant difference between this group and the remainder of our sample in relationship to the number of custody changes (Table XXIV). 
TABLE XXIV

CHI SQUARE: RELATIONSHIP BETWEEN CUSTODY CHANGES

AND WHETHER OR NOT THE MARRIAGE LASTED

LONGER THAN THE LEGAL PROCESS

\begin{tabular}{|c|c|c|c|c|c|c|}
\hline & \multicolumn{5}{|c|}{ Custody Changes } & \multirow[b]{2}{*}{ Total } \\
\hline & $\overline{0}$ & 1 & 2 & 3 & $\overline{4}$ & \\
\hline More Marriage & 33 & 13 & 16 & 1 & 0 & 63 \\
\hline More Fighting & 10 & 11 & 5 & 2 & 1 & 29 \\
\hline Total & 43 & 24 & 21 & 3 & 1 & 92 \\
\hline
\end{tabular}

The final hypothesis in our investigation of this group was that the group of 29 cases would have a greater number of actions than the remainder of our sample. We tested our hypothesis by means of Chi Square. The computed Chi Square for our sample was 2. 24. Chi Square at the .05 level with 4 degrees of freedom is 9.49. The test revealed that there was no significant difference between this group and the remainder of our sample in relationship to the number of court actions. Table XXV shows the results of the Chi Square computation.

It may be speculated that many of these couples whose postmarital conflicts continued over longer periods of time than their marriages entered marriage with the implicit as sumption that divorce is a solution to marital problems. 
TABLE XXV

CHI SQUARE: RELATIONSHIP BETWEEN THE NUMBER OF ACTIONS AND WHETHER OR NOT THE MARRIAGE LASTED LONGER THAN

THE LEGAL PROCESS

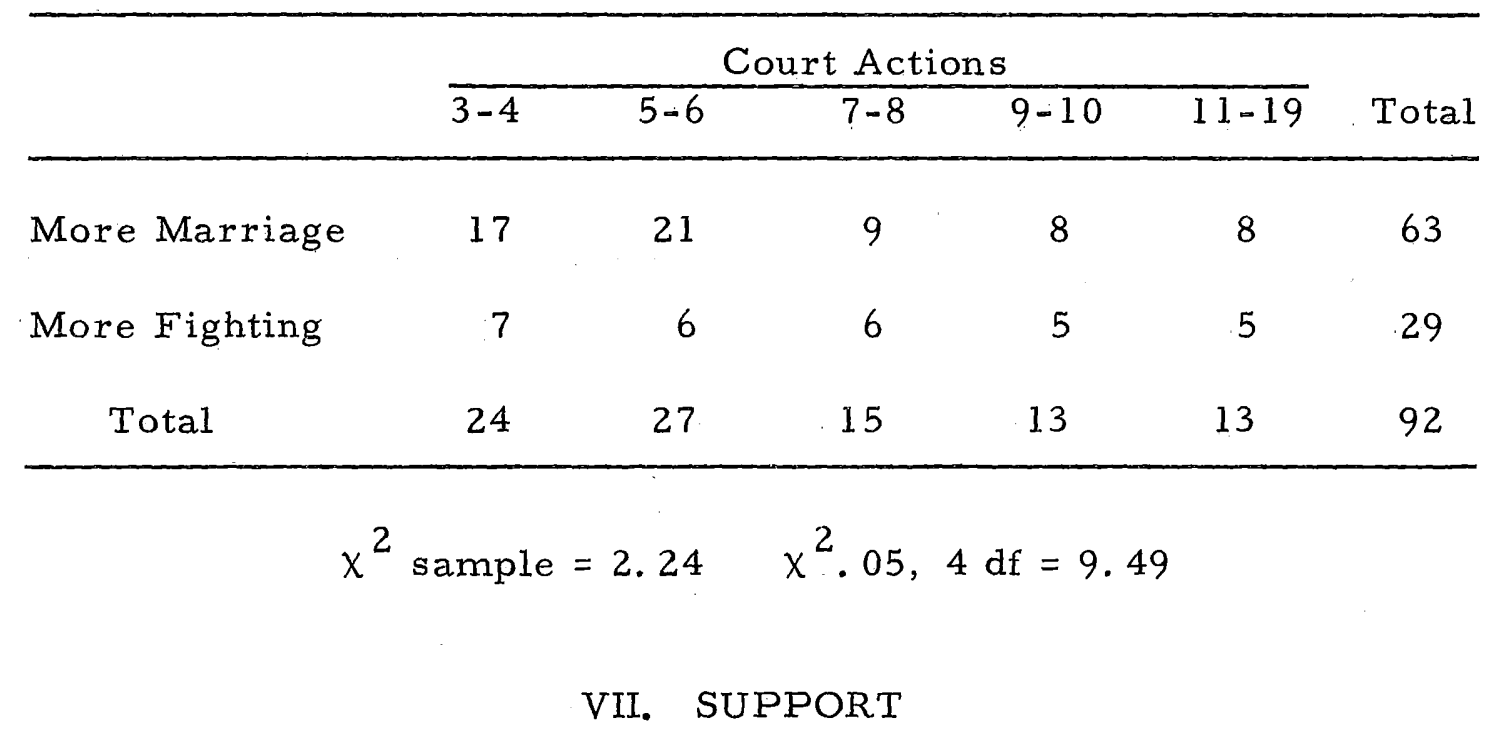

A large amount of data was collected on the subject of support. We attempted to analyze the data in such a fashion that it could easily be presented in graph form for ease of reading. We soon discovered that there were so many "exceptions to the rule" and many aspects that influenced this area of study that the only method of presentation that was realistic was in a narrative style. A specific breakdown of support requests and grants at the time of the filing and the divorce will be explained by tables following the presentation below.

At the time of filing there were 61 cases in which a request was made for a specific amount of support. 
In the Cross Complaint there were 9 cases where support was requested by the mother, along. with a request for custody of the children.

In the Show Cause Motion for Pendente Lite there were 23 requests by the wife concerning support: 7 requests for an increase in support, 2 requests for a decrease, and 14 requests that the father begin to pay support.

In the Order Pendente Lite the following were granted: 7 increases, 11 decreases, and 5 orders from the court to the fathers to begin paying support.

At the time of the Motion to Modify the Order Pendente Lite, one father requested a decrease in the amount he was paying, two mothers requested additional support, and one wife requested that her husband be forced to pay.

The Order Modifying the Order Pendente Lite granted one increase, one decrease, and ordered one husband to pay.

At the time of the Divorce Decree there were 72 cases in which support was specified, 18 cases in which support was not specified, and 2 cases in which both parents were ordered to pay support to maternal grandparents, who had legal custody.

At the first Motion to Modify the Divorce Decree there were 23 cases in which fathers wanted decreased support or support eliminated because they: were requesting a custody change, 2 cases 
in which fathers wanted support lowered because one child had reached the age of maturity, and 1 father who claimed he was unable to meet his support obligation. There was 1 request by a mother that her ex-husband be forced to meet his support obligation, 6 requests for a support increase and 4 requests from mothers that they be given custody and support. There were 29 cases in which the father asked for custody with no mention of support, but it is assumed that support would be lowered or terminated if his request was granted. There were 9 implied requests for support or an increase in support in which the mother requested custody without any mention of support.

In the Order Modifying the Divorce Decree there were 15 cases in which payments were suspended, 10 reduced, 8 increased, and 3 cases in which the father was ordered to pay. There were 9 implied reductions. where fathers received custody of all or some of the children, although no mention was made of support. There were 3. implied increases where mothers received custody of all or some of the children, although, again, no mention was made of support. The inconsistencies in data collection and the availability of data within the case records was again a problem and it was, therefore, decided not to proceed from the first Order Modifying the Divarce Decree in our investigation of support.

Tables XXVI and XXVII show the frequency distributions, the 
range, mean, and median of support per child per month at the time of filing and at the time of Divorce Decree and the total support per family per month at the time of filing and at the time of Divorce Decree.

\section{TABLE XXVI}

EREQUENCY DISTRIBUTIONS: AMOUNT OF SUPPORT PER CHILD PER MONTH AT COMPLAINT AND DIVORCE DECREE

\begin{tabular}{lcc}
\hline $\begin{array}{l}\text { Support/ } \\
\text { Month }\end{array}$ & $\begin{array}{c}\text { Complaint } \\
f\end{array}$ & $\begin{array}{c}\text { Divorce Decree } \\
\mathrm{f}\end{array}$ \\
\hline $0-25$ & 1 & 4 \\
$26-50$ & 15 & 25 \\
$51-75$ & 27 & 29 \\
$76-100$ & 9 & 9 \\
$101-125$ & 3 & 1 \\
$126-150$ & 4 & 3 \\
$151-175$ & 1 & 1 \\
$176-200$ & 1 & 0 \\
Total & 61 & 72 \\
\hline
\end{tabular}

Complaint

Range: $\quad \$ 15-200$ per child per month

N: $\quad 61$ (29 cases no support listed; 1 case support and alimony one figure; 1 case with both parents paying support)

Mean: $\quad \$ 79.54$

Median: $\$ 75.00$

Divorce Decree

Range: $\quad \$ 15-175$ per child per month

N: $\quad 72$ (18 cases no support listed; 2 cases with both parents paying support)

Mean: $\quad \$ 63.52$

Median: \$60.00 
TABLE XXVII

FREQUENCY DISTRIBUTIONS: TOTAL SUPPORT PER

FAMILY PER MONTH AT COMPLAINT

AND DIVORCE DECREE

\begin{tabular}{lcc}
\hline $\begin{array}{l}\text { Support/ } \\
\text { Month }\end{array}$ & $\begin{array}{c}\text { Complaint } \\
f\end{array}$ & $\begin{array}{c}\text { Divorce Decree } \\
\mathrm{f}\end{array}$ \\
\hline $0-50$ & 11 & 10 \\
$51-100$ & 11 & 26 \\
$101-150$ & 12 & 14 \\
$151-200$ & 8 & 11 \\
$201-250$ & 6 & 3 \\
$251-300$ & 8 & 2 \\
$301-350$ & 1 & 1 \\
$351-400$ & 1 & 3 \\
$401-450$ & 2 & 2 \\
$451-500$ & 1 & 0 \\
Total & 61 & 72 \\
\hline
\end{tabular}

Complaint

Range: $\quad \$ 40-500$ per family per month

N: $\quad 61$ (See Table XXVI)

Mean: $\quad \$ 174.26$

Median: $\$ 150.00$

Divorce Decree

Range: $\quad \$ 30-450$ per family per month

N: $\quad 72$ (See Table XXVI)

Mean: \$136.74

Median: $\$ 102.50$

The figure requested for child support is usually more than the party actually expects the court to award. Although the amount of support appears to be a negotiable factor, it is generally decreased at the time of the decree. In mostinstances the custodial parent eventually 
assumes a.large share (or all) of the financial responsibility, since the non-custodial parent either cannot or does not continue to make the payment ordered by the court.

A study made by Eckhardt (1968) of 163 fathers under court order to pay. support through divorce action during the nine-year period from 1955-1964 revealed that $84 \%$ of the se men were in deviance of the court action at some time during that period, and that only $36 \%$ of this number had legal action initiated against them.

Questions that may be asked here are:

1. How realistic is it to ask a father to pay $\$ 136.74$ (shown as mean in Table XXVII) out of his net income?

2. What happens when a man re-marries and acquires a second family to support?

The fact that many children of divorce do not have sufficient economic resources to insure their minimal physical well-being points to the need for a carefully studied and realistic plan for family allowances.

From a view of our data on support we developed the hypothesis that the larger the amount of support asked by the wife at the time of filing, the more court actions would ensue from the time of filing. It seemed plausible that fathers who were asked to pay large sums monthly: would be involved in more court actions in, perhaps, attempting to get support reduced and/or custody of the children. 
The computed Chi Square of our sample was 16.25. Chi Square at the . 05 level with 20 degrees of freedom is 31.41 , which disproved our hypothesis by indicating no significant difference in the relationship of the amount of support to the number of actions (Table XXVIII).

\section{TABLE XXVIII}

CHI SQUARE: RELATIONSHIP BETWEEN TOTAL SUPPORT PER FAMILY AT TIME OF COMPLAINT AND NUMBER OF COURT ACTIONS

\begin{tabular}{lrcccccc}
\hline & \multicolumn{7}{c}{ Actions } \\
\cline { 2 - 6 } Support & $3-4$ & $5-6$ & $7-8$ & $9-10$ & $11-19$ & Total \\
\hline None Listed & 9 & 8 & 6 & 3 & 3 & 29 \\
$\$ 100$ or Les & 6 & 8 & 2 & 4 & 2 & 22 \\
$101-200$ & 6 & 4 & 4 & 4 & 2 & 20 \\
$201-300$ & 1 & 4 & 2 & 2 & 5 & 14 \\
$301-400$ & 0 & 1 & 0 & 0 & 1 & 2 \\
$401-500$ & 2 & 0 & 1 & 0 & 0 & 3 \\
$\quad$ Total & 24 & 25 & 15 & 13 & 13 & 90 \\
\hline
\end{tabular}

Note: Two cases not used; one with mixed support and alimony; one with both parents paying support

$$
\chi^{2} \text { sample }=16.25 \quad x^{2} .05,20 \mathrm{df}=31.41
$$

As mentioned in our test of the relationship between support and court actions, we considered whether the amount of support would have any effect on the fathers' attempts to get custody of all or some of the children. Our hypothesis was that the larger the support asked for by the wife at the time of filing, the more the custody 
changes throughout the process. The computed Chi Square of our sample was 7.21. Chi Square at the 05 level with 20 degrees of freedom is 31.41. Again, no significance was found and our hypothesis was disproved. Table XXIX shows the results of the Chi Square computation.

\section{TABLE XXIX}

CHI SQUARE: RELATIONSHIP BETWEEN TOTAL SUPPORT PER FAMILY AT TIME OF COMPLAINT AND NUMBER OF CUSTODY CHANGES

\begin{tabular}{crrrrrr}
\hline & \multicolumn{5}{c}{ Custody Changes } & \multirow{2}{*}{ Support } \\
\cline { 2 - 5 } & 0 & 1 & 2 & 3 & 4 & Total \\
\hline None Listed & 14 & 7 & 6 & 1 & 1 & 29 \\
\$100 or Les & 10 & 7 & 4 & 1 & 0 & 22 \\
$101-200$ & 8 & 6 & 5 & 1 & 0 & 20 \\
$201-300$ & 8 & 2 & 4 & 0 & 0 & 14 \\
$301-400$ & 1 & 1 & 0 & 0 & 0 & 2 \\
$401-500$ & 1 & 1 & 1 & 0 & 0 & 3 \\
$\quad$ Total & 42 & 24 & 20 & 3 & 1 & 90 \\
\hline
\end{tabular}

Note: Two cases not used; see Table XXVIII

$$
\chi^{2} \text { sample }=7.21 \quad \chi^{2} .05,20 \mathrm{df}=31.41
$$

The fact that our hypothesis that the larger the support asked for by wife at time of filing, the more the custody changes, was disproved again demonstrates that the court is not unduly influenced by an individual's attempt at harassment (in this case, harassment of ex-spouse via support requests). Here again the fact that the court 
judges each case on its own merits is clearly demonstrated.

In the 29 cases in which the length of the legal activity exceeded the length of marriage, the support at the time of filing ranged from $\$ 37.50$ to $\$ 150.00$ per child per month with a mean of $\$ 73.75$ per child per month and a median of $\$ 72.50$ per child per month.

\section{VISITATION}

As noted in Chapter III, visitation was recorded in the Reading Guide as "NR" if not recorded, " $R$ " if the request was for reasonable visitation, "D" if visitation was limited to one day at a time, "O" if visitation was allowed for two or more successive days which would necessitate the child (or children) remaining overnight; space was also available on the Reading Guide to indicate any special or unusual arrangements that were indicated. In attempting to analyze our data we decided since there were so few reports listing " $D$ " or "O" for visitation, to combine the se two categories and, also, include any special and/or unusual arrangements for vistiation under the term "specification" of visitation.

Table XXX describes visitation as it occurred through the legal process.

In one-third of the 92 cases studied there were problems regarding visitation presented to the court. The table shows that in the first two motions to modify after the decree there were 30 
TABLE XXX

DESCRIPTION OF VISITATION THROUGH THE LEGAL PROCESS

\begin{tabular}{lccc}
\hline & $\begin{array}{c}\text { Not } \\
\text { Recorded }\end{array}$ & Reasonable & Specified \\
\hline Complaint & 34 & 58 & 0 \\
Cross - Complaint & 12 & 20 & 0 \\
Show Cause Motion & 28 & 3 & 0 \\
Pendente Lite & 8 & 17 & 8 \\
Motion to Modify Pendente Lite & 4 & 0 & 3 \\
Order Modifying Pendente Lite & 4 & 0 & 3 \\
Divorce Decree & 9 & 79 & 4 \\
First Order to Modify & 40 & 19 & 18 \\
Second Order & 15 & 7 & 12 \\
Third Order & 12 & 2 & 4 \\
Fourth Order & 9 & 2 & 1 \\
Fifth Order & 4 & 0 & 1 \\
Sixth Order & 2 & 0 & 0 \\
Seventh Order & 1 & 0 & 1 \\
\hline
\end{tabular}

Note: First Order to Modify contained one suspension of visitation.

Second Order to Modify contained one suspension of visitation.

specific changes to programs of visitation. This again points out that the period during the divorce is a time of disequilibrium for the family; there is need for a transition period during which the family can stabilize and reach a point where they can cope more effectively with the problems that are an aftermath of their divorce. At the time of divorce, both spouses are apt to be disorganized and unsettled; the father may be temporarily homeless, and planning cannot be done for either themselves or their children in a calm and 
rational way. The court might serve these families more realistically if visitation plans could be reviewed as the members of the family have a chance to reestablish their maximum level of functioning.

The above specifications all occurred in 35 cases. Table XXXI shows the frequency distribution of "specifications."

TABLE XXXI

FREQUENCY DISTRIBUTION OF SPECIFICATIONS OF VISITATION

\begin{tabular}{cc}
$\begin{array}{c}\text { Number of } \\
\text { Specifications }\end{array}$ & $\begin{array}{c}\text { Number of } \\
\text { Cases }\end{array}$ \\
\hline & \\
2 & 21 \\
3 & 11 \\
4 & 1 \\
5 & 1 \\
& Total \\
\hline
\end{tabular}

IX. PROPERTY, ALIMONY, COURT COSTS, ATTORNEYS' FEES, RESTRAINT FROM HARASSMENT AND MOVE FROM THE HOME

This section of our study attempts to cover the topics listed in the heading. A very limited amount of data was available on these subjects and, consequently, they will be discussed only briefly. Property is seldom listed factually in the legal file for 
two reasons:

1. This is public record and people for various reasons are hesitant to list their assets and liabilities for anyone to see.

2. Frequently there is deliberate concealment so that family possessions and assets can be used as negotiable instruments by the spouses.

At the time of the divorce, property was not recorded in 20 cases, listed as "none or limited" in 35 cases, "moderate" in 30 , and "considerable" property in 7 cases. In 64 cases there was an indication of how the property was split between the plaintiff and defendant. A rating scale was devised from the scale on the Reading Guide to measure the property at the time of the Divorce Decree. A continuum was established in which $a+7$ indicated that the plaintiff received all of the property and $a-7$ in which the defendant received all of the property with compromises noted between the two extremes. Table XXXII, following the test of our next hypothesis by means of Chi Square, shows the property split between the plaintiff and the defendant.

A hypothesis was developed that the wife, as plaintiff or defendant, would receive a larger share of the property settlement than her husband. Chi Square was computed dividing the property settlement according to the sex of the plaintiff and defendant. Chi Square of our sample was 10.63. Chi Square at the .05 level with 5 degrees 
of freedom is 11.07 , indicating no significance in the distribution of property according to the sex of the plaintiff and defendant.

TABLE XXXII

CHI SQUARE: RELATIONSHIP BETWEEN DIVISION OF PROPERTY AND THE SEX OF THE PARTIES

\begin{tabular}{|c|c|c|c|c|c|c|c|c|}
\hline & \multicolumn{3}{|c|}{ Plaintiff } & \multirow[b]{2}{*}{0} & \multicolumn{3}{|c|}{ Defendant } & \multirow[b]{2}{*}{ Total } \\
\hline & $\stackrel{+}{+}$ & $\begin{array}{c}+ \\
3-4\end{array}$ & $\stackrel{+}{1-2}$ & & $\overline{1-2}$ & $3-4$ & $\overline{-}$ & \\
\hline Husbands & 4 & 3 & 2 & & 5 & 0 & 2 & 16 \\
\hline Wives & 6 & 9 & 3 & & 0 & 3 & 3 & 24 \\
\hline Total & 10 & 12 & 5 & $(24)$ & 5 & 3 & 5 & $40+(24)=64$ \\
\hline
\end{tabular}

Note: The evenly split " 0 " interval was not included in the computation of Chi Square

$$
x^{2} \text { sample }=10.63 \quad x^{2} .05,5 \mathrm{df}=11.07
$$

The table shows that division of property is not determined by sex, but that there is a tendency for the plaintiff to receive a larger share than the defendant. This again concurs with Metz's (1968) contention that the outcome of the divorce proceedings favors the plaintiff, although it does not bear out his statement that the court is prejudiced in favor of the wife.

Attorneys' fees and court costs at the time of the Divorce Decree were not asked for and not granted in 47 cases. There were no requests for attorneys' fees, or court costs, recorded in 3 case 
records in which the court did specify an amount to be paid. Of the 42 cases requesting attorneys' fees and court costs, a mean amount requested was $\$ 248.76$. In the 45 , cases in which a sum was awarded the mean amount was $\$ 290.77$.

At the time of the Divorce Decree, alimony: was requested by wives in 14 cases, but granted by the court in 24 cases. Of these 24 cases, 5 consisted of lump sum awards with a range of $\$ 5.00$ to $\$ 2,850,00$. Of the remaining 19 cases in which monthly alimony payments were granted, the mean monthly payment was $\$ 72.97$. It was noted that in 5 of these 19 cases, alimony payments were terminated at the end of one year.

At the time of the Show Cause Motion for Pendente Lite, a Restraint from Harassment was requested in 12 cases and granted with the Order Pendente Lite in 7 cases. Also, at the Order Pendente Lite, there were 3 cases in which a Restraint from Harassment was ordered against both parties. In one case a Restraint from moving the children from the court's jurisdiction was requested at the time of the Show Cause Motion for Pendente Lite and this request was granted in the Order Pendente Lite.

At the time of the Show Cause Motion for Pendente Lite, there were four requests by one party. for the court to order the other party from the family home. At the time of the Order Pendente Lite, in five cases the court ordered one party to move from the family home. 


\section{THE FAMILY SERVICES DEPARTMENT}

The Family Services Department of the Court of Domestic Relations was involved in 47 cases of the sample on 54 occasions. Figure 16 shows where in the legal process the Family Services Department intervened in our sample.

Speculation here is that one-half of the sample that the Family Services Department saw had problems of such severe nature they were not amenable to resolution through adversary proceedings. It is suggested that if a subsequent study were done to determine what happens after the Family Services Department intervenes, it would indicate only one additional visit to the court.

It was decided to investigate those who had seen Family Services and those who had not in relationship to the number of court actions. Our hypothesis was that those who saw Family Services would have less court actions than those who had not. The computed Chi Square of our sample was 10.46. Chi Square at the .05 leve1 with 4 degrees of freedom is 9. 49, which indicated a significant difference between the two groups. The primary area of difference was in the nine to ten court actions interval in which the Family Services Department was involved with 11 cases, where the expected number was 6.6. In the group that had not seen Family Services, there were 2 cases where the expected frequency was 6.4. These findings 
Complaint

Answer and Cross Complaint

Show Cause Motion

Answer to Show Cause

Pendente Lite Order

Order Modifying Pendente Lite

Divorce Decree

First Motion to Modify

First Order Modifying

Second Motion

Second Order

Third Motion

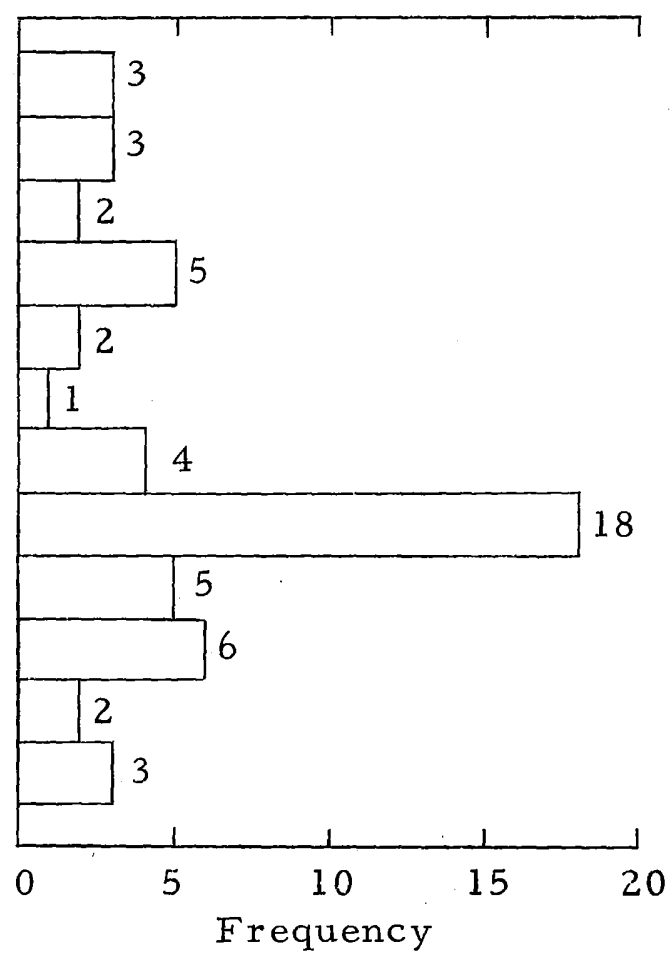

'Figure 16. Places of intervention in the legal process by the Family. Services Department. 
indicate the reverse of our hypothesis in that those cases that were seen by: Family Services had more court actions than those who had not seen Family Services (Table XXXIII).

TABLE XXXIII

CHI SQUARE: RELATIONSHIP BETWEEN NUMBER OF COURT ACTIONS AND WHETHER OR NOT FAMILY SERVICES DEPARTMENT WAS SEEN

\begin{tabular}{lccccccc}
\hline & \multicolumn{5}{c}{ Actions } & \\
\cline { 2 - 6 } Cases Seen & $9-4$ & $5-6$ & $7-8$ & $9-10$ & $11-19$ & Total \\
\hline Cases Not Seen & 15 & 16 & 5 & 2 & 7 & 45 \\
Total & 24 & 27 & 15 & 13 & 13 & 92 \\
\hline & $x^{2}$ sample $=10.46$ & $x^{2} .05,4 \mathrm{df}=9.49$ &
\end{tabular}

Table XXXIII shows that out of the 92 cases, 47 were seen by the Family Services Department. This table highlights the fact that in the year 1965 the court did not use the Family Services Department to the fullest extent, in that there were 45 cases where custody was at is sue and there were large numbers of actions that received no social work services. This can undoubtedly be accounted for through the court interpretations of Supreme Court rulings that modifications of decree are based solely on the legal concept of 
"change of circumstances," rather than on the individual needs of the child or the child's maximum psychosocial development. ${ }^{1}$

${ }^{1}$ Effective April 1969, the Honorable Jean L. Lewis has reappraised this position, and the Department of Family Services provides services to all cases involving problems with children, including those with modification of decrees. 


\section{CHAPTER V}

\section{IMPLICATIONS FOR FURTHER STUDY, LIMITATIONS AND CONCLUSIONS}

In evaluating the results of this study; we found that a pattern of individualization began to emerge. The judges of the Court of Domestic Relations in Multnomah County, recognizing that the law cannot cover every situation, seem to personalize decisions as much as possible in their efforts to give paramount consideration to the best interests of the child. Each family that comes before the court is seen as unique; each case is given individual consideration based on the carefully thought-out judgment and discretion of the court. In many instances it is difficult to determine what is in the best interests of the child. The situation which each parent has to offer may be relatively equal. A jurist is required to distinguish between subtle variations of fact and feeling in material which is presented in a stylized and artificial manner. Between the vagueness of the law and the importance of their mission, judges are thought to be omniscient, which on its face is an unrealistic societal expectation. As we viewed our overall results we felt that the judges who had been instrumental in making the decisions on the cases we had examined deserved a large measure of credit for their special efforts 
to make wise and impartial decisions.

Just as there are no hard and set standards for making decisions in the intricate area of domestic relations, the interpretation of this study should be made with a constant awareness of the uniqueness of each of the 92 families under consideration. In developing the previous chapter much care was taken to avoid a tendency to oversimplify: or generalize. In spite of many similarities which the statistics reveal, each of the families is composed of individuals who are different in themselves as well as in their relationship to each other.

Although the original purpose of our study was to describe the people who become involved in the court system through their need for modification of a previous ruling, we found that we also described the court process through which they had to pass. Our study: was thus broadened beyond its intended scope; we found we could not meaningfully separate people and process since they are so intricately interwoven.

\section{LIMITATIONS AND CONCLUSIONS OF THIS RESEARCH PROJECT}

Throughout the study two major underlying assumptions of a somewhat contradictory nature caused the group to fluctuate between "good" and "bad" judgments concerning our investigation. Is it good 
or bad to move children from one home to another? Is the court process a healing or a hurting activity? At times the group would be pulled in one direction, at other times in the other direction. There were times when we may not have been as objective as we would have liked, due to these fluctuations. Our ambivalence can be explained by an awareness of the complexity of the many factors involved, the major ones being the changing needs of the child at different developmental stages and the multiplicity of changes affecting the parents as they emerge from the divorce process. Because human conditions are subject to constant change, it is imposible to state whether moving children or the continuation of the legal process is good or bad per se. Our overriding conclusion is that the court is in fact a problem-solving resource for families who are unable to cope with the problems of child custody after divorce.

We concluded that our study was further limited by the following factors:

1. No control group was used.

2. We did not identify the party to whom the decree of divorce was awarded. This was not expected to have been a significant factor but it should have been measured.

3. As stated under the heading Implications for Further Study, we did not conduct interviews but based our study on material taken from court files. 
4. The material on which our study. was based was a matter of public record; therefore, the information was distorted to some extent, especially in the areas of property settlement and particulars at the time of the complaint. Many documents. were out of order in the file or were missing altogether.

5. The size of our sample was small and limited to one year.

6. We did not compare cases in which there were no custody changes; i.e., where the child remained with the parent given custody in the original divorce decree.

\section{IMPLICATIONS FOR FURTHER STUDY}

Our study revealed 47 cases out of our sample in which the Department of Family Services had been involved. This social agency adjunct to the legal system could be expected to have much meaningful material relating to the group of people studied. One of the obvious areas of further study is a detailed review of these 47 cases and the collection of additional explanatory and descriptive data. A comparison could be made between these 47 cases and the remaining 45 cases to see if there is any meaningful significance between the se two groups. Some of the reasons for instituting court action would be more explicitly: stated and thereby subject to measure. The foregoing data describes people and process but not why. Further study 
would seem to be mandatory for a clearer understanding of the factors involved in the lives of people which necessitates such a sweeping change as moving a child from one home to another.

This study constituted a review of legal files from an objective view. While we described many things, we have included nothing of the participants' view. Further study could involve personal interviews with these people in order to measure and assess attitudes and feelings about their experiences as they have engaged with the court system. Also personal interviews would tend to reveal some additional underlying dynamics involved in precipitating the types of human crises which make continuing court action necessary. Information gained from personal interviews could be compared with information contained in Family Consultant files, which could be not only explanatory but perhaps also provide a basis for evaluation of Family Consultant services.

In most states divorce and custody legislation is being looked at in a new and critical light. Changes are unquestionably indicated but in considering the type of new legislation to institute, more direct information is needed from the participants in the legal process. This includes the people appearing before the court for redress, the judges who must make such fundamental decisions, the attorneys who in representing their clients before the court must take a biased and one-sided position, and the social workers who 
have both an evaluative and advisory role to the court. It is on this combined experience and knowledge that new legislation should be based.

This study is a significant beginning in contributing to the meager research in the area of divorce and custody. Much of the literature in this area is limited by lack of adequate documentation and thorough research. In view of the growing number of individuals involved in the divorce process it is hoped that further research will be done to help identify problems inherent in divorce and to help the people involved to cope effectively with the myriad of problems surrounding it.

\section{ADDENDUM}

A recent book relevant to our study is When Parents Divorce: A New Approach to New Relationships, by Bernard Steinzor. Since the book was published just as our thesis was being completed, it is not included in our chapter on Review of the Literature. 


\section{A SELECTED BIBLIOGRAPHY}

\section{GENERAL REFERENCES}

Arkin, Herbert and Raymond R. Colton. Tables for Statisticians, Second Edition. New York, Barnes and Noble, 1950. 168 p.

Bardis, Panos D. "Family; Forms and Variations Historically Considered, "Handbook of Marriage and the Family. Edited by Harold T. Christensen. Chicago, Rand McNally, 1964. p. 403-461.

Blanck, Rubin and Gertrude Blanck. Marriage and Personal Development. New. York, Columbia University'Press, 1968. 188 p.

Coughlin, Bernard J.. "The Rights of Children," Child Welfare; 47:3. March, 1968. p. 133-142.

Despert, Juliette Louise, M. C. Children of Divorce. New York, Dolphin Books, Doubleday, 1962. 298 p.

Dominian, Jack. Marital Breakdown. England, Penguin Books Ltd. , 1968. $167 \mathrm{p}$.

Drummond, Isabel. Getting a Divorce. New York, Alfred Knopf, 1931. 498 p.

Eckhardt, K. W. "Deviance, Visibility, and Legal Action: The Duty to Support," Social Problems, 15:4. 1968. p. 470-477.

Elkin, Meyer. "Short-Contact Counseling in a Conciliation Court," Social Casework, 43:4. April, 1962. p. 184-190.

Erikson, Erik H. Childhood and Society. New York, W. W. Norton and Company, 1950. 429 p.

Furlong, Robert. "Dual Divorce Decrees and Conciliation in Contemporary Family Law, "Willamette Law Journal, 2:2. 1962. p. $134-171$. 
Glasser, Paul H. and Elizabeth Navarre. "Structural Problems of the One-Parent Family, "Behavioral Science for Social Workers. Edited by; Edwin J. Thomas. New York, The Free Press, 1967. p. 145-155.

Glasser, William. Lecture in series, "Adolescence and its Problems," Portland Civic Auditorium, Portland, Oregon, January 16, 1970.

Glueck, Sheldon and Eleanor Glueck. Unraveling Juvenile Delinquency. New York, The Commonwealth Funds, 1950. 399 p.

Goode, William, After Divorce. Glencoe, Illinois, The Free Press, 1956. $366 \mathrm{p}$.

Hansen, Robert W. (LL. B.) "The Role and Rights of Children in Divorce Actions, "Journal of Family Law, 6:1. Spring, 1966. p. $1-14$.

Hansen, Robert W. and Sidney J. Goldberg. "Casework in a Family Court, "Social Casework 48:7. July, 1967. p. 416-421.

Haussamen; Florence and Mary Anne Guitar. The Divorce Handbook. New York, G. P. Putnam's Sons, 1960. 256 p.

Hunt, Morton M. The World of the Formerly Married. Greenwich, Connecticut, Fawcett Publications, Inc., 1967. 243 p.

Kal, Frederick M. and Henry A. Frumes. Divorce Problems Handbook: A Practical Guidebook to Divorce Problems and the Law of Divorce in the Fifty States. New York, Frederick Fell, 1961. $237 \mathrm{p}$.

Lodge, Thomas L. "Modification of Divorce Decrees with Respect to the Custody of Minor Children--Oregon, "Willamette Law Journal, 2:2. 1962. p. 216-226.

Madden, Joseph W. Handbook of the Law on Persons and Domestic Relations. St. Paul, West Publishing, 1931. $748 \mathrm{p}$.

Mayer, Michael F. Divorce and Annulment in the Fifty States. New York, Arco Publishing Company, 1967. 86 p.

Metz, Charles V. Divorce and Custody for Men. New York, Doubleday, 1.968. 147 p. 
Nye, F. Ivan. "Child Adjustment in Broken and in Unhappy, Unbroken Homes, "Sourcebook in Marriage and the Family. Edited by Marvin B. Sussman. Boston, Houghton Mifflin, 3rd edition. 1968. p. 434-440.

Oregonian, The. "Michigan Judges Claim Reasons for Divorce Remain Obscure." Portland, Oregon. November 16, 1969.

Ploscowe, Morris. The Truth About Divorce. New York, Hawthorn Books, 1955. 309 p.

Seattle Times. "Psychologist to Continue Fight for Custody of Daughter." Byline: Larry Brown, Seattle Washington. The Seattle Times, November 30, 1969.

Steinzor, Bernard. When Parents Divorce: A New Approach to New Relationships. New York, Pantheon Books, 1969. 243 p.

Thomson, Helen. The Successful Stepparent. New York, Harper Row, 1966. $237 \mathrm{p}$.

Truxal, Andrew G. and Erancis E. Merrill. Marriage and the Family in American Culture. New York, Prentice-Hall, 1953. $571 \mathrm{p}$.

United States Bureau of the Census, Statistical Abstract of the United States, 1969, 90th edition. Washington, D. C. , 1969.

Virtue, Maxine Boord. Family Cases in Court. Durham, North Carolina, Duke University Press, 1956. 290 p.

\section{OREGON SUPREME COURT CASES}

Bennehoff vs. Bennehoff, Oregon Supreme Court Reports, volume 209, p. 224-226. December 31, 1956. Per Curiam.

Bogh vs. Lumbattis, Oregon Supreme Court Reports, volume 203, p. 298-306. February 16, 1955. C. J. Warner, author.

Cox vs. Cox; Oregon Supreme Court Reports, volume 247, p. 614615. September 20, 1967. Per Curiam. 
Gallagher vs. Gallagher, Oregon Supreme Court Reports, volume 187, p. 625-634. December 29, 1949. J. Rossman, author.

Gibson vs. Gibson, Oregon Supreme Court Reports, volume 196, p. 198-218. October 1, 1952. J. Rossman, author.

Goldson vs. Goldson, Oregon Supreme Court Reports, volume 187, p. 206-219. October 18, 1949. J. Rossman, author.

Hendrickson vs. Henrickson, Oregon Supreme Court Reports, volume 225, p. 398-405. January 11, 1961. J. Warner, author.

James vs. James, Oregon Supreme Court Reports, volume 245, p. 144-146. November 30, 1966. J. Redding, author.

Kightlinger vs. Kightlinger, Oregon Supreme Court Reports, volume 249, p. 521-526. April 10, 1968. J. Goodwin, author.

Kroll vs Kroll, Oregon Supreme Court Reports, volume 241, p. 576579. November 10, 1965. J. Schwab, author.

Pick vs. Pick, Oregon Supreme Court Reports, volume 197, p. 7483. December 23, 1952. J. Tooze, author.

Shrout vs. Shrout, Oregon Supreme Court Reports, volume 224, p. 521-527. November 9, 1960. C. J. McAllister, author.

Tingen vs. Tingen, Oregon Supreme Court Advance Sheets, volume 87, No. 5, p. 365-368. November 6, 1968. J. Mengler, author. 
APPENDICES 
APPENDIX A

READING GUIDE

\section{COMPLAINT}

1. Case \# Date of filing

2. Plaintiff Age H. W. Defendant Age H. W.

3. Marriage: Date Place Length

4. Children:

5. Grounds:

6. Particulars:

7. Custody: P1tf: Def. Split

8. Visitation: NR $R$ D O Special

9. Support: Alimony

10. Property: NR NL M C Pltf. all Def. all

II. ANSWER: date filed

III. CROSS COMPLAINT: date filed

1. Grounds:

2. Particulars: 
3. Custody: Pltf.

Def. Split

4. Visitation: NR $R$ D O Special

5. Support Alimony

6. Property: NR NL M C Pltf. all Def. all

IV. SHOW-CAUSE MOTION FOR P. L. : who filed date

1. Custody: Pltf. Def. Split

2. Visitation: $N R$ R $D$ O Special.

3. Support Alimony

4. Restraint from harassment Move from house

5. Attorney's fees

V. ANSWER TO SHOW-CAUSE MOTION: Date filed

VI. ORDER PENDENTE LITE: Date filed

1. Custody: Pltf. Def. Split

2. Visitation: NR $R$ D O Special

3. Support Alimony

4. Restraint from harassment Move from house

5. Attorney's fees Referral to F.C.O.

VII. MOTION TO MODIFY P.L. ORDER:

Date By whom filed

1. Custody

2. Visitation

3. Support

4. Particulars 
VIII. ORDER MODIFYING P. L. ORDER: Date

1. Custody

2. Visitation

3. Support

IX. DIVORCE DECREE: date Time lapse

1. Custody: Pltf. Def. Split

2. Visitation NR R D O Special

3. Support Alimony

4. Attorney's fees and court costs: n. a. f. requested by awarded to

5. Property: NR NL M C Pltf. all Def. all

X. MOTION TO MODIFY DIVORCE DECREE: Date by whom time lapse

1. Custody

2. Visitation

3. Support Alimony

4. Changed circumstance

XI. ORDER MODIFYING DIVORCE DECREE: Date Time Lapse

1. Custody

2. Visitation

3. Support Alimony 
XII. FAMILY CONSULTANT ACTIVITY:

1. Conciliation Service: date began (on minute order)

2. Family Consultant: date (on cover of legal file)

XIII. OTHER 


\section{APPENDIX B}

\section{CODE SHEET}

I. 3. Marriage: Give date, city and state where marriage took place. Calculate length of marriage in years and months from marriage date to date of filing.

4. Children: Name in first column, age in second. If sex of child is not obvious from name, i. e. Marion, indicate sex.

6. Particulars:
A. Loss of love
B. Late hours
C. Third party (paramour)
D. Neglect of children
E. Physical abuse: describe, i.e. stabbing, shooting, etc.
F. Verbal abuse: describe, i. e. nagging, ridiculing, etc.
G. Desertion
H. Jealousy
I. Relative interference: indicate relationship, if known
J. Non-support
K. Gambling
L. Alcoholism
M. Other: specify

7. Custody: If split, indicate how.

8. $\begin{aligned} \text { Visitation: } & N R=\text { not recorded } & & R=\text { reasonable } \\ D & =\text { daytime } & & O=\text { overnight }\end{aligned}$

Circle appropriate category; if none applies, give details in "special" category.

9. Support: Give figures in $\$ /$ month/child.

Alimony: Indicate whether $\$ /$ month or lump sum; indicate if request is made for legal fees. 


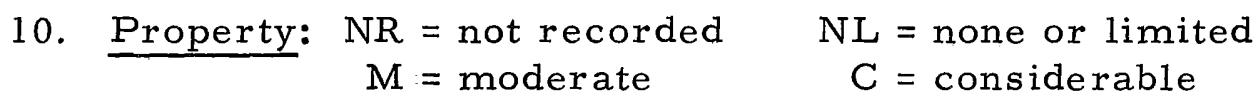

Circle appropriate category. Indicate how property split whether in favor of defendant or plaintiff.

III. 2. Particulars: Use code for I, 6.

VI. If by stipulation, note in margin "STIP" and date.

VIII. If by stipulation, note in margin "STIP" and date.

IX. Divorce Decree: For time lapse, calculate in months the length of time elapsed from date of filing of complaint (I) to date of Divorce Decree (IX).

4. Attorney's fees: n, a.f. = none asked for.

X. Motion to Modify Divorce Decree: For time lapse, calculate in months the time elapsed from date of divorce decree to date of filing motion.

XI. Order Modifying Divorce Decree: For time lapse, calculate in months the time elapsed from date motion to modify to date of order.

XIII. Other: Indicate anything unique taking place not covered above. For example, if an answer to a motion to modify Pendente Lite order is filed, note here. 